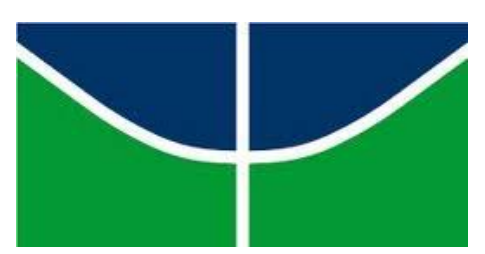

UNIVERSIDADE DE BRASÍLIA

FACULDADE DE AGRONOMIA E MEDICINA VETERINÁRIA

INCLUSÃO DO CLA NA DIETA DE MATRIZES DE CORTE E TEMPOS DE ARMAZENAMENTO DE OVOS INCUBÁVEIS SOBRE O RENDIMENTO DA INCUBAÇÃO E QUALIDADE DA PROGÊNIE

PRISCILA SOARES SILVÉRIO

DISSERTAÇÃO DE MESTRADO EM CIÊNCIAS ANIMAIS

BRASÍLIA-DF

JULHO DE 2016 


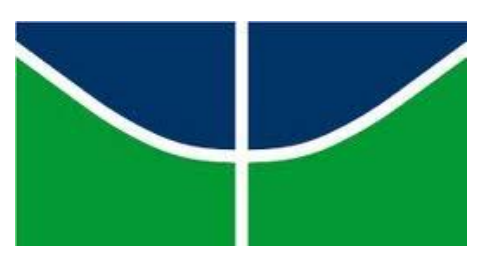

UNIVERSIDADE DE BRASÍLIA

FACULDADE DE AGRONOMIA E MEDICINA VETERINÁRIA

\title{
INCLUSÃO DO CLA NA DIETA DE MATRIZES DE CORTE E TEMPOS DE ARMAZENAMENTO DE OVOS INCUBÁVEIS SOBRE O RENDIMENTO DA INCUBAÇÃO E QUALIDADE DA PROGÊNIE
}

\author{
PRISCILA SOARES SILVÉRIO \\ ORIENTADORA: PROF ${ }^{a}$. DRA. ALINE MONDINI CALIL RACANICCI
}

DISSERTAÇÃO DE MESTRADO EM CIÊNCIAS ANIMAIS

PUBLICAÇÃO: 170/2016

BRASÍLIA-DF

JULHO DE 2016 


\section{REFERÊNCIA BIBLIOGRÁFICA E CATALOGAÇÃo}

SILVÉRIO, P.S. Inclusão do CLA na dieta de matrizes de corte e tempos de armazenamento de ovos incubáveis sobre o rendimento da incubação e qualidade da progênie. Brasília: Faculdade de Agronomia e Medicina Veterinária, Universidade de Brasília, 2016, 98p. Dissertação de mestrado.

Documento formal, autorizando a reprodução desta dissertação de mestrado para empréstimo ou comercialização, exclusivamente para fins acadêmicos, foi passado pelo autor à Universidade de Brasília e acha-se arquivado na Secretaria do Programa. O autor e o seu orientador reservam para si os outros direitos autorais, de publicação. Nenhuma parte desta dissertação de mestrado pode ser reproduzida sem a autorização por escrito do autor ou do seu orientador. Citações são estimuladas desde que citada a fonte.

FICHA CATALOGRÁFICA

SOARES SILVERIO, PRISCILA

SP959i Inclusão do CLA na dieta de matrizes de corte e tempos de armazenamento de ovos incubáveis sobre o rendimento da incubação e qualidade da progênie. / Priscila Soares Silvério; Orientadora: Aline Mondini Calil Racanicci Brasília, 2016.

$98 \mathrm{p}$

Dissertação (Mestrado em Ciências Animais) - Faculdade de Agronomia e Medicina Veterinária, Universidade de Brasília, 2016.

1. Qualidade dos ovos incubáveis 2. Qualidade dos pintos 3. Morfometria dos órgãos 4. Oxidação lipídica. I. Racanicci, Aline Mondini Calil, oriente. II. Título. 


\section{UNIVERSIIDADE DE BRASÍLILA (UNB)}

FACULDADE DE AGRONOMIIA E MIEIICINA VETERINÁRIIA (FAV)

INCLUSÃO DO CLA NA DIETA DE MATRIZIES DEE CORTE E TEMTPOS DE ARMAZENAMIENTO DEE OVOS INCUBÁVEIS SOBRE O RENIDIMENTO IDA INCUBAÇÃO E QUALIIDAIDE IDA PROGIENIIE

PIRISCILA SOARIES SILVÉEIIO

DISSERTAÇÃO DE MIESTRADO SUBBMETIDA À COORIDENAÇ̃̃O DO PROGRAIMA DE PÓS-GRADUAÇÃO EMI CIIÉNCIAS ANIIMAIIS, COMIO PARTE DOS REQUISITTOS NECESSÁRIOS À OBTENÇÃO DO GRAU DE MESTRE EM CIIÊNCIIAS ANIIMAIIS.

APROVAIDA POR:

Alivedalie

Prof?. IDra. ALINIE M. CAILIL RACANICCI

ORIIENTADORA - Universidade de Brasilia (UnB)

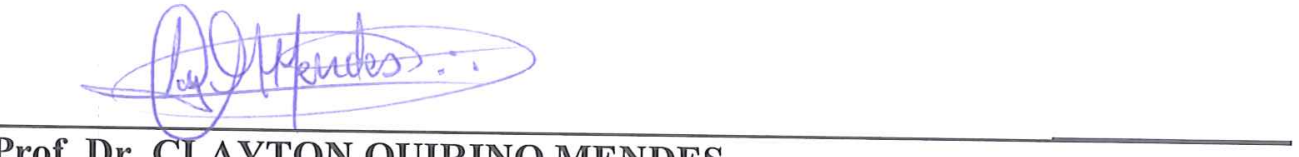

Prof. Dr. CLAYTON QUIRINO MIENDIES

Universidade de Brasília (UnB)

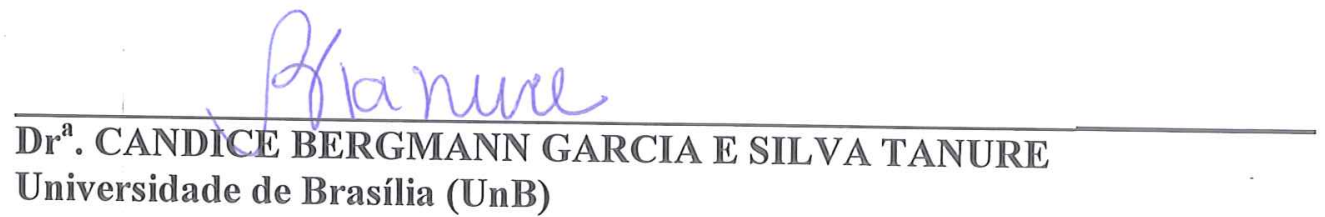

BRASÍLIAA-DF, 15 DE JULHO DE 2016 
Dedico este à minha família, aos meus pais tão amados, Anunciação Soares e Pedro Silvério e meu irmão amado, Franklin Soares Silvério. Vocês são e sempre serão a razão de tudo. 


\section{AGRADECIMENTOS}

Agradeço à Deus, que sempre me ilumina e ampara em todos os momentos.

À minha amada mãe, Anunciação Soares, muito obrigada por tudo, desde companhia nas madrugadas em claro junto aos artigos até os cuidados para que eu não me esquecesse de alimentar-me em meio aos estudos, te amo incondicionalmente.

À professora Dra. Aline Mondini Calil Racanicci pela orientação, amizade, ensinamentos, apoio, compreensão e principalmente, pela abertura de novas experiências que não se limitam somente ao âmbito acadêmico, mas também profissional e pessoal.

À Dra. Candice Bergmann Garcia e Silva Tanure por toda a ajuda, em especial em momentos mais difíceis e mesmo com suas crianças pequenas estava sempre disposta à colaborar, ensinar e participar de todos os momentos.

À empresa Bonasa Alimentos S/A pela confiança e parceria para execução da pesquisa. Bem como a todos os seus colaboradores envolvidos para que tudo fosse possível.

Aos amigos do incubatório Bonasa Alimentos S/A que trabalharam brilhantemente para execução das fases mais delicadas do experimento, com zelo, carinho e muito amor, Sérgio Maestrelo, Kaio Paiva (muito obrigada pelas inúmeras horas de almoço perdidas na execução das etapas experimentais), Márcia, Elisiário e todos os envolvidos neste. Aprendi muito com todos vocês, muito obrigada!

À querida amiga Cristiane Bovi de Lima pelas incontáveis horas dispendidas no planejamento e execução de todas as etapas deste. Pelas noites e noites passadas em laboratório. 
A todos os amigos que participaram de todas as etapas, desde as coletas das amostras até às análises laboratoriais: Érika Lays, Thais Chiozzini, Débora Euclydes, Dannielle Migotto, Iamylle Carmo, Oberdan Thomáz, Estéfany Martins, Pedro Marins e muitos outros que ajudaram e apoiaram em diversos momentos.

À minha amiga Karina Dosualdo pelo incentivo ao ingresso no programa de pós graduação da UnB. Pela amizade, carinho, ajuda e presença não só neste, mas em grandes momentos da minha caminhada.

À minha amiga Larissa Bernardi Aguiar pelo apoio em diversos momentos muito difíceis.

À minha amiga Ana Paula Matias pela ajuda, apoio, compreensão e presença nos momentos de dificuldade.

Aos professores do programa de pós-graduação em Ciências Animais da Universidade de Brasília que foram grandes e verdadeiros mestres nessa caminhada.

Muito obrigada! 


\section{ÍNDICE}

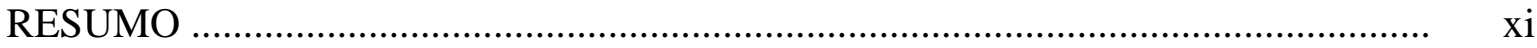

ABSTRACT ..............................................................................................

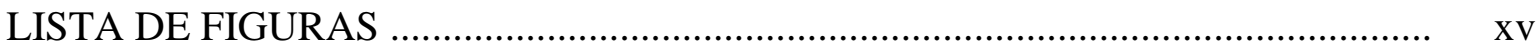

LISTA DE TABELAS …….......................................................................... xvii

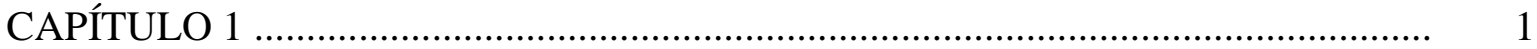

1 INTRODUÇÃO ............................................................................................ 2

2 REVISÃO DE LITERATURA 4

2.1 Fatores que afetam os resultados de incubação e qualidade dos pintos de matrizes pesadas.

2.1.1 Qualidade externa do ovo.................................................................................

2.1.2 Qualidade interna do ovo................................................................................ 5

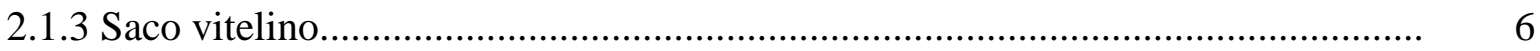

2.1.4 Ácidos graxos do saco vitelino ........................................................................ 6

2.1.5 Oxidação lipídica ………………………………………………………...

2.2 Armazenamento de ovos incubáveis ..................................................................... 9

2.2.1 Condições ambientais ideais para o armazenamento, perda de peso do ovo durante o armazenamento e zero fisiológico

2.2.2 Relação da idade da matriz, peso do ovo, eclodibilidade, peso e qualidade do pintinho.

2.2.3 Metabolismo dos ácidos graxos durante o processo de incubação e influência do armazenamento

2.2.4 Armazenamento, mortalidade embrionária e qualidade do pinto ........................ 13

2.3 Ácido linoléico conjugado (CLA) na produção de pintos de corte .............................. 15

2.3.1 Principais isômeros do ácido linoléico ( $\omega 6)$ e estrutura molecular dos cis-9, trans-11 e trans-10, cis-12 ………………………….................................... 15

2.3.2 Fontes de CLA ……..................................................................................... 15

2.3.3 Características e propriedades dos isômeros de CLA ………………………….... 16

2.3.4 CLA dietético na produção de ovos incubáveis .................................................. 16

2.3.5 CLA dietético, embriogênese e mortalidade da progênie de matrizes pesadas 18

2.3.6 Peroxidação, capacidade antioxidante dos tecidos embrionários dos pintos e efeito antioxidante do CLA dietético ……………………………………………..... 19

2.3.7 Metabolismo e efeitos do CLA dietético nas matrizes pesadas e na progênie ..... $\quad 20$

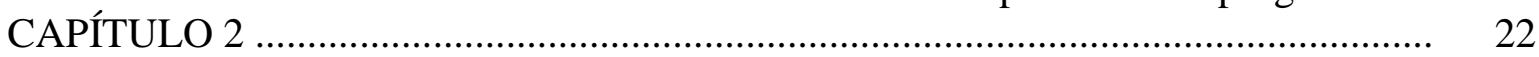

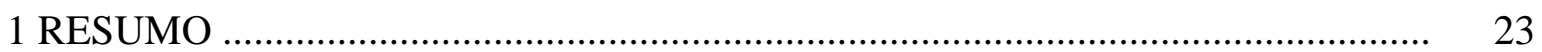

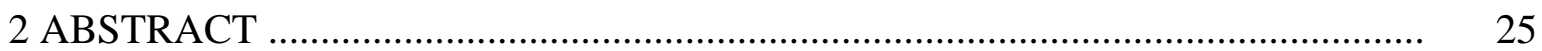

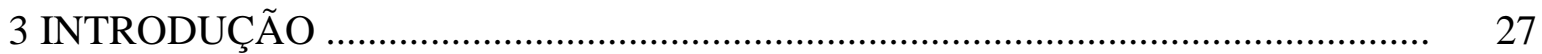

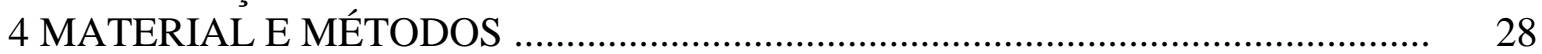

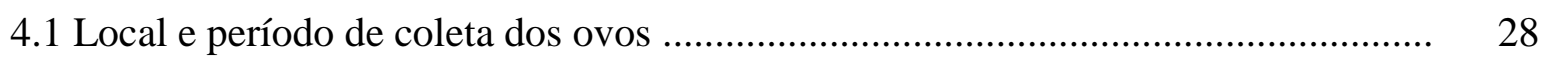

4.2 Manejo nutricional ............................................................................... 28

4.3 Tratamentos experimentais ........................................................................... $\quad 30$

4.4 Classificação e armazenamento dos ovos incubáveis ............................................. 30

4.5 Qualidade dos ovos incubáveis armazenados em diferentes períodos com ou sem CLA ………........................................................................................ 31 


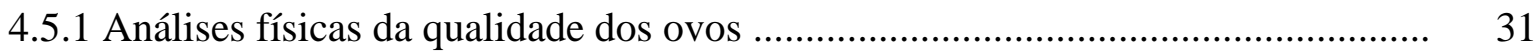

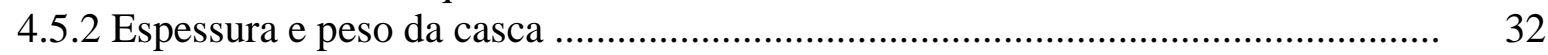

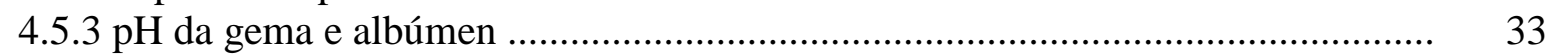

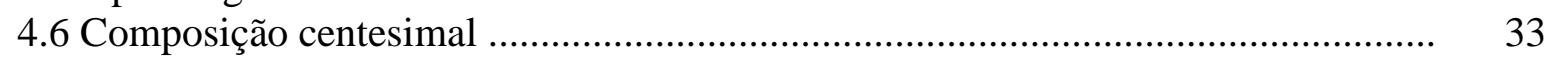

4.6.1 Determinação de umidade ............................................................................ 33

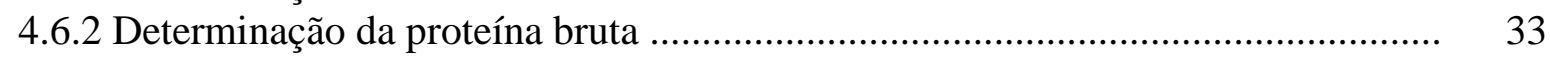

4.6.3 Determinação do extrato etéreo das gemas ........................................................ 34

4.6.4 Determinação da matéria mineral................................................................ 34

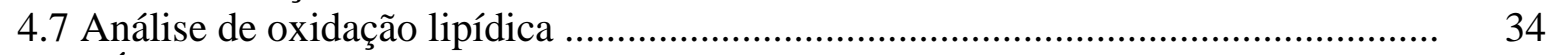

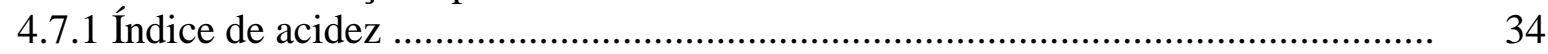

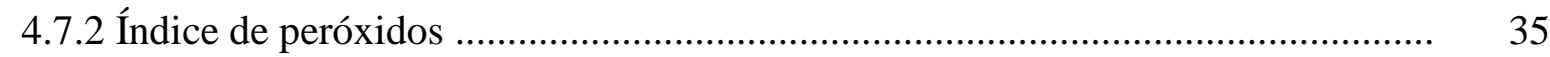

4.7.3 Substâncias reativas ao ácido tiobarbitúrico (TBARS).................................... 35

4.8 Delineamento experimental e análise estatística 36

5 RESULTADOS E DISCUSSÃO ........................................................................ 37

5.1 Qualidade dos ovos incubáveis armazenados em diferentes períodos com ou sem

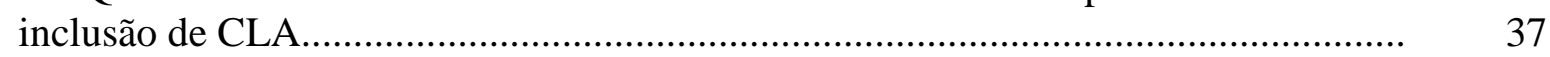

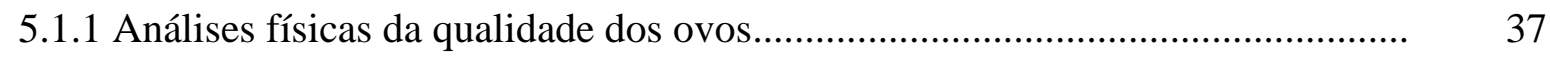

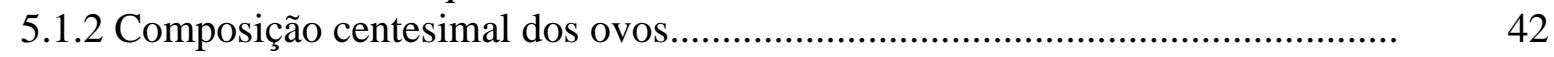

5.1.3 Oxidação lipídica de ovos armazenados em diferentes períodos na sala de ovos $\quad 45$

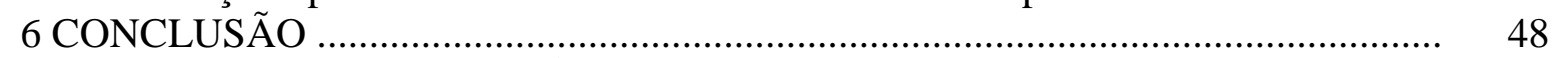

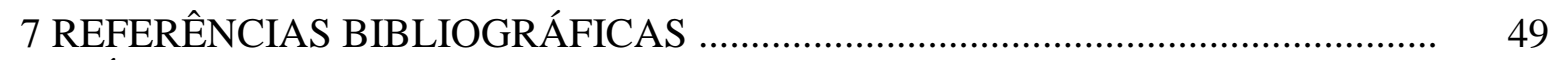

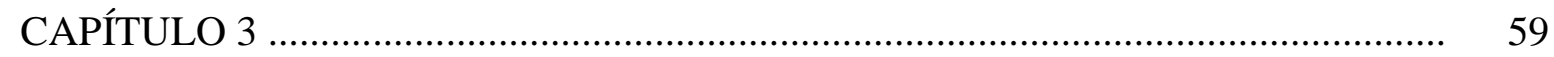

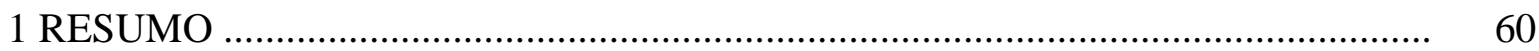

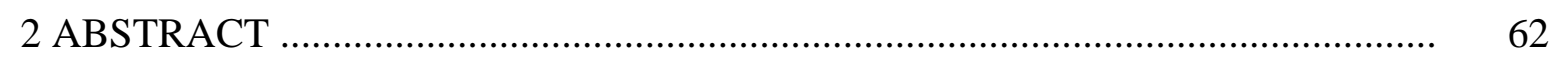

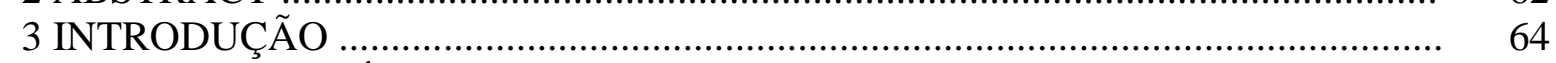

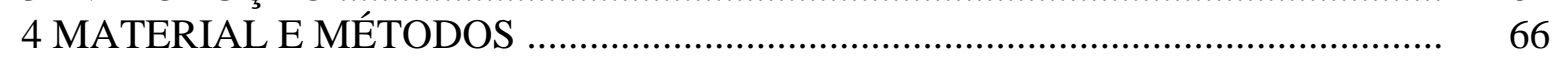

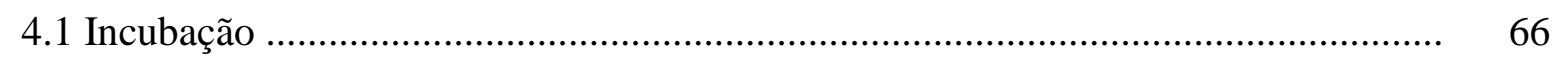

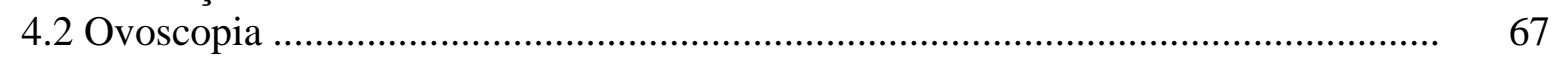

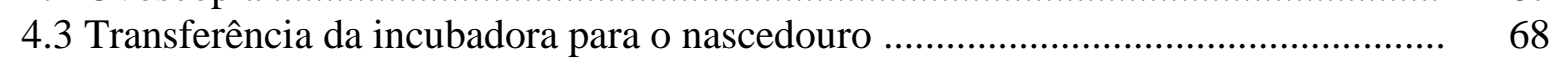

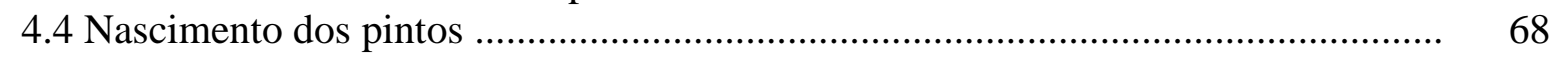

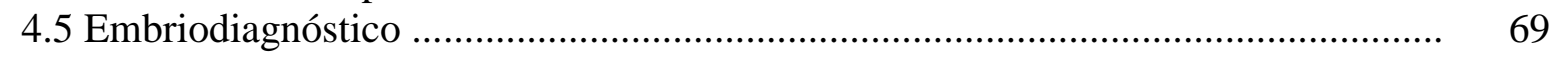

4.6 Parâmetros de incubação e desempenho da progênie ............................................... 69

4.6.1 Perda de peso do ovo durante armazenado em diferentes períodos na sala de

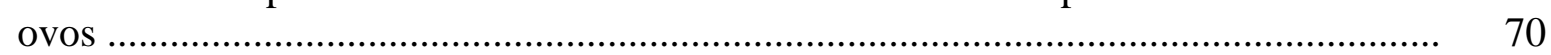

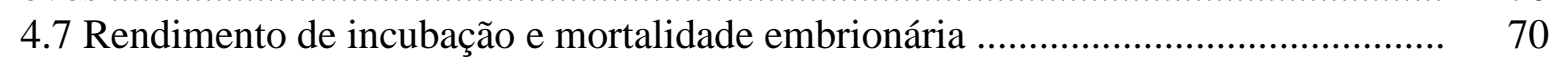

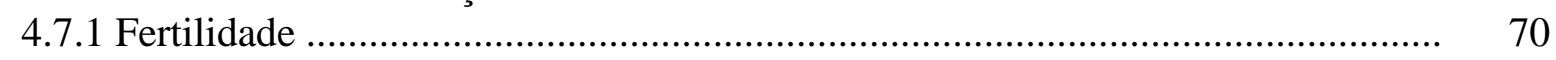

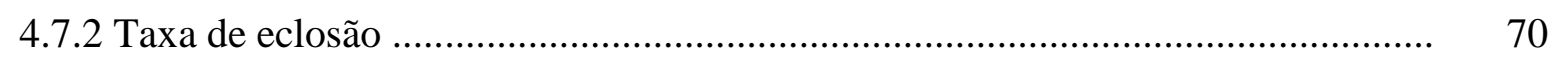

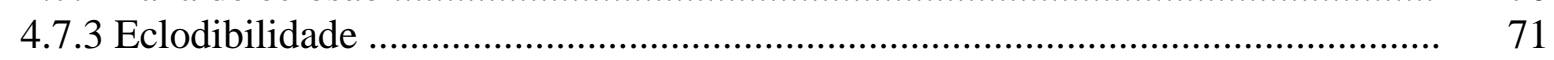

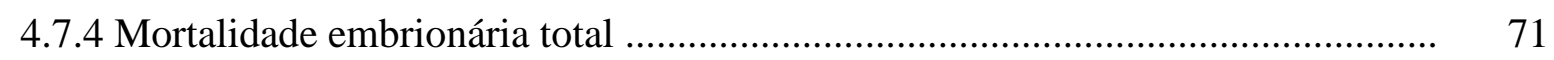

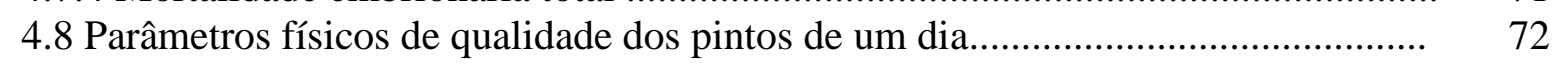

4.8.1 Avaliação da qualidade dos umbigos dos pintos de um dia .............................. 72

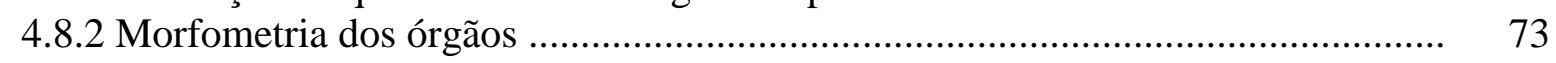

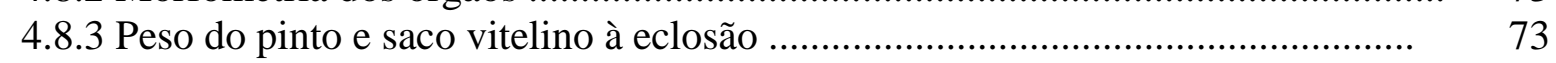

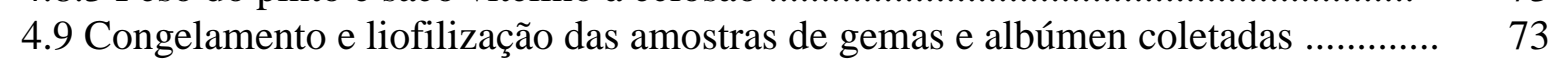

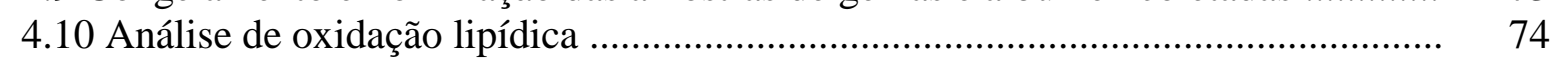

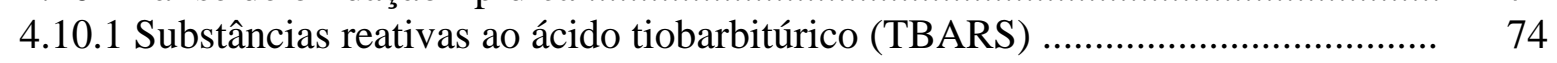

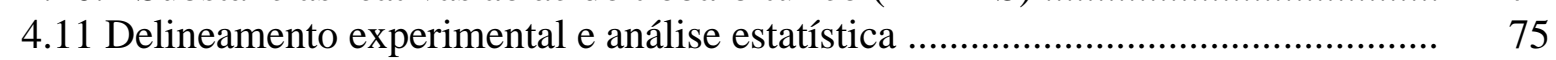

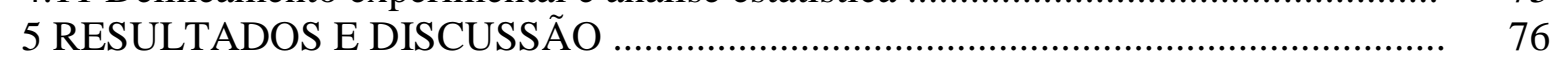

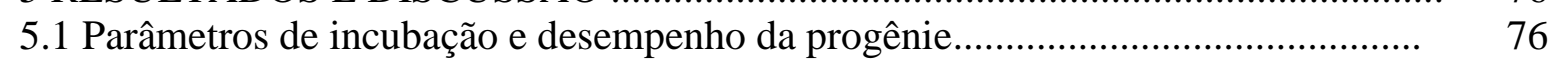

5.1.1 Perda de peso do ovo armazenado em diferentes períodos na sala de ovos ......... 76 
5.1.2 Rendimento de incubação e mortalidade embrionária …................................. 78

5.1.2.1 Causas de mortalidade embrionária ............................................................ 83

5.1.3 Parâmetros físicos de qualidade dos pintos de um dia...................................... $\quad 84$

5.1.3.1 Avaliação da qualidade dos umbigos dos pintos de um dia ....................... 86

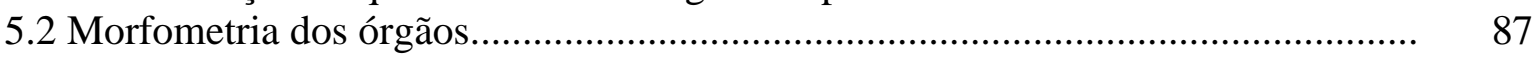

5.3 Oxidação lipídica dos sacos vitelinos de pintos de um dia................................. 93

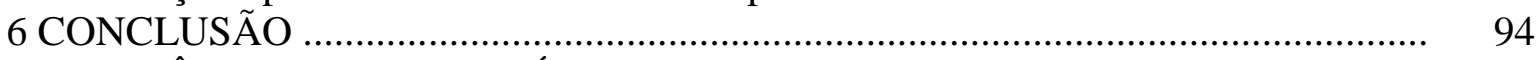

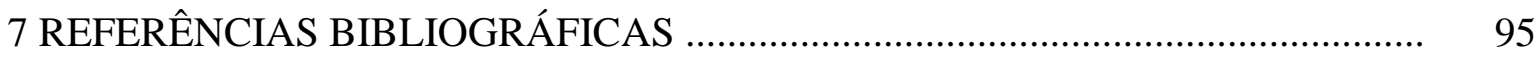


RESUMO

\title{
INCLUSÃO DO CLA NA DIETA DE MATRIZES DE CORTE E TEMPOS DE ARMAZENAMENTO DE OVOS INCUBÁVEIS SOBRE O RENDIMENTO DA INCUBAÇÃO E QUALIDADE DA PROGÊNIE
}

\author{
DISCENTE: PRISCILA SOARES SILVÉRIO ${ }^{1}$ \\ ORIENTADORA: Prof ${ }^{\mathrm{a}}$. Dr' ${ }^{\mathrm{a}}$. ALINE MONDINI CALIL RACANICCI ${ }^{1}$ \\ ${ }^{1}$ Universidade de Brasília - UNB
}

Foram conduzidos dois experimentos para avaliar o efeito da inclusão dos isômeros cis-9, trans-11 e trans-10, cis-12 de ácido linoléico conjugado (CLA) na dieta de matrizes pesadas e do armazenamento dos ovos incubáveis durante três, seis ou nove dias na sala de ovos do incubatório. Os tratamentos foram definidos pelas dietas (com inclusão de 0,023\% de CLA ou sem CLA) oferecidas para 22.000 matrizes pesadas da linhagem Cobb® em fase de postura com idades entre 58 e 60 semanas e os tempos de armazenamento (três, seis ou nove dias). Na primeira fase experimental foram utilizados 6.912 ovos distribuídos em delineamento inteiramente casualisado em esquema fatorial 2x3 (com ou sem inclusão de CLA nas dietas das matrizes x 3 períodos de armazenamento). Foram amostrados 30 ovos por tratamento para a avaliação dos parâmetros físicos de qualidade: peso, altura, porcentagem, pH de gema e albumen, proporção gema:albúmen, diâmetro e índice de gema, Unidade Haugh, peso, espessura e porcentagem de casca, composição centesimal e oxidação dos lipídios da gema 
usando TBARS (substâncias reativas ao ácido tiobarbitúrico), índice de peróxidos e acidez. $\mathrm{Na}$ segunda fase experimental, foram utilizados 1.152 ovos por tratamento divididos em 12 bandejas (repetições com 96 ovos cada) de incubação. Após passarem pelos diferentes períodos de armazenamento (três, seis ou nove dias) os ovos foram incubados no mesmo dia em incubadora de múltiplo estágio. Foram realizadas as avaliações de ovoscopia e embiodiagnóstico para determinação das fases da mortalidade embrionária (inicial, média e tardia), além da perda de peso ao armazenamento, fertilidade, taxa de eclosão, eclodibilidade, mortalidade embrionária e suas causas, parâmetros físicos de qualidade dos pintos de um dia e qualidade dos umbigos dos pintos recém-eclodidos. Após a eclosão, foi realizada a morfometria dos órgãos, sendo avaliados os pesos do fígado, do pâncreas, dos intestinos e do saco vitelino e o comprimento dos intestinos em uma amostra de 35 pintos/tratamento. Nas amostras coletadas do saco vitelino foram realizadas análises de oxidação dos lipídios através da metodologia de TBARS. Os dados obtidos foram analisados adotando um modelo misto, com efeito fixo para os tratamentos e aleatórios para os períodos de armazenamento e as médias foram comparadas pelo teste de Tukey com significância de 5\%. Na primeira fase foi observado que a progressão dos tempos de armazenamento afetou negativamente $(\mathrm{P}<0.05)$ a qualidade física e a composição centesimal dos ovos incubáveis, porém a inclusão do CLA na dieta das matrizes minimiza esses efeitos, especialmente em ovos armazenados durante nove dias. Na segunda fase foi observado que os maiores períodos de armazenamento prejudicaram os parâmetros de eclodibilidade e qualidade dos pintos, no entanto, a inclusão do CLA na dieta das matrizes pesadas apresentou efeitos positivos somente para os ovos armazenados por nove dias, reduzindo os danos oxidativos aos lipídios durante o processo de armazenamento.

Palavras-chave: qualidade dos ovos incubáveis, qualidade dos pintos, morfometria dos órgãos, oxidação lipídica. 


\title{
ABSTRACT \\ INCLUSION OF CLAIN BROILER BREEDERS HENS FED DIET AND TIMES OF HATCHING EGGS STORAGE ON INCUBATION YIELD AND QUALITY OF PROGENY
}

\author{
GRADUATE STUDENT: PRISCILA SOARES SILVÉRIO ${ }^{1}$ \\ ADVISOR: PhD. Dra ${ }^{\mathrm{a}}$ ALINE MONDINI CALIL RACANICCI ${ }^{1}$ \\ ${ }^{1}$ University of Brasília - UNB
}

Two experiments were conducted to evaluate the effect of the inclusion of cis-9, trans-11 and trans-10, cis-12 conjugated linoleic acid isomers (CLA) in the diet of broiler breeders and storage of hatching eggs during three, six and nine days in the hatchery egg room. The treatments were defined by breeders diets (with the inclusion of 0,023\% CLA or without CLA) offered total of 22.000 broiler breeders $\mathrm{Cobb}{ }^{\circledR} 58$ and 60 weeks during laying phase and the storage periods (three, six nine days). During the first experimental phase, 6.912 eggs were distributed for each storage period at the eggs room in a completely randomized in a $2 \times 3$ factorial (with or without the inclusion of CLA in the diets x 3 storage periods). Thirty (30) eggs per treatment were used to perform physical parameters of egg quality such as weight, height, percentage, $\mathrm{pH}$ yolk and albumen, yolk ratio: albumen, diameter and yolk index, Haugh unit, weight, thickness and percentage of eggshell, chemical composition and oxidation yolk lipids using TBARS (thiobarbituric acid reactive substances), peroxide value 
and acidity. In the second experimental phase, 1.152 eggs per treatment were distributed in a complete randomized design to 12 trays (repetitions with 96 eggs per tray) for incubation at the same time in a multi-stage incubator. Candling and embryo evaluations were conducted to determine the stages of embryo mortality (early, middle and late), the weight loss during storage, fertility, hatching rate, hatchability, embryo mortality and physical parameters of quality of one-day chicks and quality of navels of newly hatched chicks. After hatching, morphometry of the organs was performed din 35 birds per treatment by assessing liver weights, pancreas, intestines, and yolk sac, and the length of intestines. Lipid oxidation was performed in the yolk sac collected from newly hatched chicks using TBARS method. Data were analyzed using a mixed model with fixed effects for treatment and random to storage periods and the averages were compared by Tukey test (5\% significance). In the first phase it was observed that the progression of storage time negatively affected $(\mathrm{P}<0.05)$ the physical quality and chemical composition of hatching eggs, as expected, however, the dietary CLA minimized these effects, particularly for nine days of storage. In the second phase, it was observed that longer storage periods damaged the parameters of hatchability and quality of the chicks, however, dietary CLA showed positive effects on eggs stored for nine days, and reduced oxidative damage to lipids during the storage process.

Keywords: quality of the hatching eggs, chick quality, organs morphometry, lipid oxidation. 


\section{LISTA DE FIGURAS}

\section{CAPÍTULO 1}

Figura 1.1 Estrutura do ovo......

Figura 1.2 Movimento relativo dos lipídios do saco vitelino aos embriões de pintos via membrana do saco vitelino. Pesos totais dos lipídios do conteúdo total do saco vitelino, membrana do saco vitelino e tecidos embrionários durante a última semana de incubação

Figura 1.3 Estrutura do ácido linoléico e suas principais conjugações c9,t11 C18:2 e $\mathrm{t} 10, \mathrm{c} 12 \mathrm{C} 18: 2$

\section{CAPÍTULO 2}

Figura 2.1 Esquema das bandejas armazenadas na sala de ovos 31

Figura 2.2 Identificação das bandejas e ovos

Figura 2.3 "Pools" de gemas e albúmen, avaliações de altura de albúmen, altura de gema e diâmetro de gema.......................................................................................... 32

Figura 2.4 Micrômetro digital................................................................................ 32

Figura 2.5 - pHmetro digital..................................................................... 33

Figura 2.6 Amostras de gemas liofilizadas para análise de peróxidos .......................... 35

Figura 2.7 Análise de peróxidos............................................................................... 35

\section{CAPÍTULO 3}

Figura 3.1 Esquema das bandejas de incubação na incubadora ................................. 67

Figura 3.2 Ovoscopia de bandeja experimental....................................................... 67

Figura 3.3 Ovoscópio dentro da incubadora.............................................................. 67

Figura 3.4 Bandejas de eclosão............................................................................. 68

Figura 3.5 Nascedouro com ovos experimentais..................................................... 68

Figura 3.6 Pintos em gavetas do nascedouro............................................................ 69

Figura 3.7 Gavetas de nascimento............................................................................. 69 
Figura 3.8 Pesagem das bandejas no incubatório................................................. 70

Figura 3.9 Embrião A1 .............................................................................. 71

Figura 3.10 Pinto com umbigo não cicatrizado................................................. 72

Figura 3.11 Liofilizador com amostras experimentais.......................................... 74

Figura 3.12 Moagem das amostras................................................................. 74 


\section{LISTA DE TABELAS}

\section{CAPÍTULO 2}

Tabela 2.1 Composição percentual e calculada das rações experimentais

Tabela 2.2 Valores médios do peso (PG, g), diâmetro ( $\mathrm{DG}, \mathrm{mm}$ ), altura ( $\mathrm{AG}, \mathrm{mm}$ ), índice (IG) e porcentagem (G\%) de gema, proporção gema:albúmen (PGA) e pH de gemas provenientes de ovos armazenados durante 3,6 ou 9 dias com e sem inclusão de CLA.

Tabela 2.3 Desdobramento da interação entre tempos de armazenamento e inclusão ou não de CLA no diâmetro da gema (DG).

Tabela 2.4 Valores médios de peso (PA, g), altura (AA, mm), porcentagem (A\%), Unidade Haugh (UH) e pH de albumens provenientes de ovos armazenados durante 3, 6 ou 9 dias com e sem inclusão de CLA

Tabela 2.5 Desdobramento da interação entre tempos de armazenamento e inclusão ou não de CLA no pH do albúmen.

Tabela 2.6 Valores médios do peso (PC, g) espessura (EC, $\mathrm{mm})$ e porcentagem $(\mathrm{C} \%)$ de cascas de ovos provenientes de ovos armazenados durante 3, 6 ou 9 dias com e sem inclusão de CLA.

Tabela 2.7 Desdobramento da interação entre tempos de armazenamento e inclusão ou não de CLA na espessura das cascas de ovos (EC) em milímetros (mm)

Tabela 2.8 Valores médios percentuais (\%) de umidade das gemas (UG), umidade do albúmen (UA), matéria mineral das gemas (MMG), matéria mineral do albúmen (MMA), proteína bruta das gemas (PPG), proteína bruta do albúmen (PBA) e extrato etéreo das gemas (EEG) provenientes de ovos armazenados durante 3, 6 ou 9 dias com e sem inclusão de CLA.

Tabelas 2.9 Valores médios da avaliação das substâncias reativas ao ácido tiobarbitúrico das gemas (TBARSG) e índices de acidez das gemas (IAG) provenientes de ovos armazenados durante 3, 6 ou 9 dias com e sem inclusão de CLA

Tabela 2.10 Desdobramento da interação entre tempos de armazenamento e inclusão ou não de CLA no índice de TBARS nas gemas (TBARSG), em $\mu$ mol MDA/kg de gemas. 
Tabela 2.11 Desdobramento da interação entre tempos de armazenamento e inclusão ou não de CLA nos índices de acidez IA (mg de $\mathrm{NaOH} / \mathrm{g}$ de gordura) das gemas de ovos

\section{CAPÍTULO 3}

Tabela 3.1 Valores médios do peso inicial $\left(\mathrm{PO}_{\mathrm{ig}}\right)$ e perda de peso percentual (PPO, \%) dos ovos armazenados durante 3, 6 ou 9 dias com e sem inclusão de CLA

Tabela 3.2 Desdobramento da interação entre tempos de armazenamento e inclusão ou não de CLA no peso do ovo inicial $\left(\mathrm{PO}_{\mathrm{i}}\right)$

Tabela 3.3 Valores médios percentuais (\%) de fertilidade (FERT), taxa de eclosão (TXEC), eclodibilidade (ECL), mortalidade embrionária total (MET), mortalidade embrionária (0 a 7), (8 a 14) e (15 a 21) dias, bicado vivo (BicV) e bicado morto (BicM) de ovos armazenados durante 3, 6 ou 9 dias com e sem inclusão de CLA

Tabela 3.4 Desdobramento da interação entre tempos de armazenamento e inclusão ou não de CLA na taxa de eclosão dos pintos (TXEC).

Tabela 3.5 Desdobramento da interação entre tempos de armazenamento e inclusão ou não de CLA na eclodibilidade dos pintos (ECL)

Tabela 3.6 Desdobramento da interação entre tempos de armazenamento e inclusão ou não de CLA na mortalidade embrionária total dos pintos (MET)

Tabela 3.7 Desdobramento da interação entre tempos de armazenamento e inclusão ou não de CLA na mortalidade embrionária dos pintos de 0 a 7 dias de incubação

Tabela 3.8 Desdobramento da interação entre tempos de armazenamento e inclusão ou não de CLA na mortalidade embrionária dos pintos bicados vivos à eclosão (BicV) ......

Tabela 3.9 Valores médios percentuais (\%) de embriões contaminados (CT), contaminação fúngica (CTF), ovos trincados (TR) com posicionamento incorreto da cabeça (P1), posicionados de forma invertida ao polo do ovo (P2) e má formação embrionária (A1) provenientes de ovos armazenados durante 3, 6 ou 9 dias com e sem inclusão de CLA

Tabela 3.10 Valores médios percentuais (\%) de mortos pós-eclosão (MPE), pintos de $1^{\mathrm{a}}$ linha $\left(1^{\mathrm{a}} \mathrm{L}\right)$, pintos de $2^{\mathrm{a}}$ linha $\left(2^{\mathrm{a}} \mathrm{L}\right)$ e pintos eliminados (ELIM) provenientes de ovos armazenados durante 3, 6 e 9 dias com e sem inclusão de CLA 
Tabela 3.11 Desdobramento da interação entre tempos de armazenamento e inclusão ou não de CLA para os pintos de um dia classificados como de primeira linha ( $\left.1^{\mathrm{a}} \mathrm{L}\right) \%$

Tabela 3.12 Valores médios percentuais (\%) de umbigos não cicatrizados e eliminados (UE), umbigos não cicatrizados e não eliminados (UNE) e total de umbigos não cicatrizados (UT) de pintos de um dia provenientes de ovos armazenados durante 3, 6 ou 9 dias com e sem inclusão de CLA

Tabela 3.13 Valores médios, em gramas (g), de peso absoluto do pinto (PP), peso absoluto do pró-ventrículo e moela (PPM), peso absoluto do fígado (PF), peso absoluto do pâncreas (PPan), peso absoluto dos intestinos (PI) e peso absoluto do saco vitelino (PSV) de pintos de um dia provenientes de ovos armazenados durante 3, 6 e 9 dias com e sem inclusão de CLA.

Tabela 3.14 Desdobramento da interação entre tempos de armazenamento e inclusão ou não de CLA no peso absoluto do pró-ventrículo e moela (g) dos pintos de um dia (PPM)

Tabela 3.15 Desdobramento da interação entre tempos de armazenamento e inclusão ou não de CLA no peso absoluto do fígado (g) dos pintos de um dia (PF)

Tabela 3.16 Desdobramento da interação entre tempos de armazenamento e inclusão ou não de CLA no peso absoluto dos intestinos dos pintos de um dia (PI) em (g) ..........

Tabela 3.17 Valores médios percentuais (\%) de pesos relativos do pinto (PPrel), próventrículo e moela (PPMrel), fígado (PFrel), pâncreas (PPanRel), intestinos (PIrel) e saco vitelino (PSVrel) de pintos de um dia provenientes de ovos armazenados durante 3, 6 ou 9 dias com e sem inclusão de CLA.

Tabela 3.18 Desdobramento da interação entre tempos de armazenamento e inclusão ou não de CLA no peso relativo (\%) do pró-ventrículo e moela dos pintos de um dia (PPMrel)

Tabela 3.19 Desdobramento da interação entre tempos de armazenamento e inclusão ou não de CLA no peso relativo (\%) do fígado dos pintos de um dia (PFrel)

Tabela 3.20 Valores médios de comprimento, em centímetros $(\mathrm{cm})$, do intestino total (CIT), do intestino delgado (CID) e do reto (CR) de pintos de um dia provenientes de ovos armazenados durante 3, 6 ou 9 dias com e sem inclusão de CLA

Tabela 3.21 Valores médios da avaliação das substâncias reativas ao ácido tiobarbitúrico dos sacos vitelinos (TBARSS) de pintos provenientes de ovos armazenados durante 3, 6 ou 9 dias com e sem inclusão de CLA 


\section{CAPíTULO 1}




\section{INTRODUÇÃO}

Conhecido principalmente por sua atividade antioxidante (Stangle, 2000; Du et al., 2001; Joo et al., 2002; Ko et al., 2004), anticancerígena (Basu et al., 2000; Kilian et al., 2002) e redutor da gordura corporal (Leung \& Liu, 2000; Park \& Pariza, 2007), o CLA, ácido linoléico conjugado, pode ser uma alternativa para a avicultura industrial visando aumentar e melhorar a produtividade de pintos de um dia.

O CLA é um conjunto de isômeros posicionais geométricos do ácido linoléico, cujos isômeros biologicamente relevantes são c9, t11 e t10, c12 (EFSA, 2016; Aydin \& Cook, 2009). É encontrado principalmente em alimentos derivados de animais ruminantes (EFSA, 2016) e possui sua síntese química através da isomerização de ácido linoléico (Banni, 2002).

Contudo, a inclusão do CLA na dieta das matrizes pode modificar o tamanho dos ovos, gema e albúmen (Suksombat et al. 2006), alterar o perfil de ácidos graxos das gemas (Aydin \& Cook, 2009; Suksombat et al. 2006) e com isso afetar a eclodibilidade, causando aumento da mortalidade embrionária que pode chegar a 100\% ao nível de inclusão de $0,5 \%$ na dieta das matrizes (Aydin \& Cook, 2009; Muma et al., 2006). Sendo assim, o nível de inclusão à dieta das matrizes é de suma importância para a expressão dos efeitos positivos do CLA sobre a progênie (Aydin \& Cook, 2009; Muma et al., 2006; Suksombat et al. 2006).

Do mesmo modo, a necessidade do armazenamento de ovos férteis na indústria avícola é uma realidade. Porém, períodos prolongados de armazenamentos diminuem a qualidade dos componentes do ovo que são essenciais ao embrião (Karoui et al., 2006; Barbosa et al. 2008) e podem comprometer o desenvolvimento embrionário, eclodibilidade 
(Macari et al., 2013) e a qualidade do pintinho (Brand et al., 2010). Quanto mais tempo os ovos são armazenados, piores são os índices (Cobb, 2013), pois os embriões de ovos armazenados por longos períodos têm o seu crescimento comprometido (Fasenko, 2007), algumas vezes, de maneira irreversível, com morte celular resultando em alta mortalidade embrionária (Fasenko et al., 2001; Fasenko, 2007).

Mais um fator agravante é que os tecidos dos embriões possuem alto grau de insaturação e estão sujeitos à peroxidação (Ko et al., 2004), sendo assim, faz se importante a busca por alternativas que possam aumentar a qualidade e barreira antioxidante dos ovos armazenados por maiores períodos.

O objetivo deste estudo foi avaliar os efeitos da adição do ácido linoléico conjugado (CLA) nas dietas de matrizes pesadas e do tempo de armazenamento de ovos quanto aos aspectos relacionados à qualidade do ovo incubável e de pintos de um dia, estabilidade oxidativa dos lipídios das gemas e sacos vitelinos, fertilidade, desenvolvimento embrionário, eclodibilidade e morfometria dos órgãos e índices morfométricos. 


\section{REVISÃO DA LITERATURA}

2.1 Fatores que afetam os resultados de incubação e a qualidade dos pintos de matrizes pesadas

\subsubsection{Qualidade externa do ovo}

A cutícula é uma película proteica que cobre a superfície externa da casca (Nascimento \& Salle, 2003) formando uma barreira contra a invasão patogênica e é importante no processo respiratório embrionário (Hunton, 2005) e cria uma barreira que inibe a desidratação do ovo (Rose-Martel et al. 2012). Abaixo dessa, situa-se a casca mineralizada do ovo, formada por carbonato de cálcio $(96,5 \%)$ e matriz orgânica $(3,5 \%)$, sendo magnésio, fósforo e outros oligoelementos (Nys et al., 2004) que possui diversos poros e duas membranas da permitem a transferência de umidade e dióxido do carbono do interior do ovo para o meio externo e a entrada de oxigênio para o interior (Macari et al., 2013).A idade da matriz influencia na qualidade da casca, uma vez que as matrizes velhas possuem qualidade de casca inferior, isso porque o peso do ovo aumenta com a idade, porém a deposição mineral na casca não muda, tornando as cascas mais finas (Roland et al., 1979). Matrizes novas apresentam ovos mais leves, com menor número de poros por $\mathrm{cm}^{2}$, maior percentual de casca em relação ao peso do ovo, maior peso específico, resistência e espessura da casca (Barbosa et al., 2012). Com o avanço da idade da matriz, o ovo aumenta de tamanho, a unidade Haugh e altura de albúmen, qualidade interna e da casca diminuem (Carvalho et al., 2007). A espessura 
da casca também diminui à medida que a idade da matriz aumenta, a qualidade da casca é avaliada pela sua espessura e porcentagem de casca e pode ser afetada pela genética, idade e fase de produção das matrizes, intensidade de produção e fatores externos como níveis nutricionais (Ledvinka et al., 2011) e equilíbrio na suplementação de cálcio e fósforo das matrizes (Venglovska et al., 2014).

\subsubsection{Qualidade interna do ovo}

O conteúdo do ovo (Fig. 1.1) é utilizado pelo embrião para seu desenvolvimento (Meijerhof, 2009). O albúmen fornece água, minerais e proteínas para o embrião em desenvolvimento e o protege das infecções microbianas pela presença de lisozima que age sobre as paredes celulares das bactérias. A partir do $12^{\circ}$ dia de incubação, o embrião ingere o liquido amniótico contendo as proteínas do albúmen, que são levadas para o trato alimentar. Outra parte do albúmen é absorvida pelo saco vitelino, aumentando a quantidade de proteína na gema (Deeming, 2002). Durante a incubação, a composição do ovo muda consideravelmente devido à utilização do albúmen para o desenvolvimento embrionário e, ao final da incubação, o albúmen é reduzido a um estreito tubo, transformando-se em um pequeno filamento que permanece ligado ao saco da gema (Macari et al., 2013).

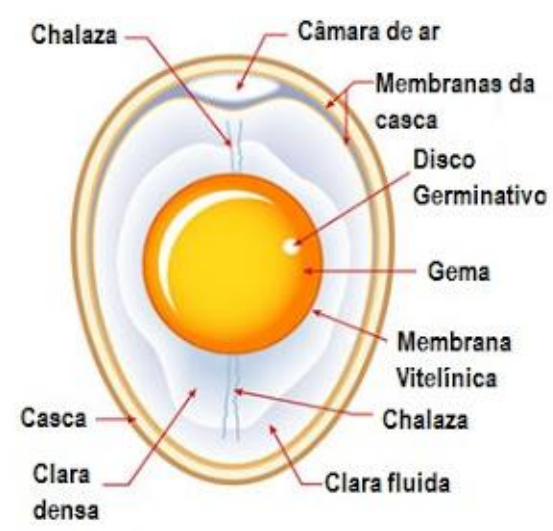

Figura 1.1 Estrutura do ovo

(Fonte: Mazzuco, 2008).

A gema é rica em lipídios e é fonte primária de energia para o desenvolvimento embrionário. Além disso, também é importante fonte proteica, sendo absorvida através da membrana vascularizada do saco vitelino que transfere nutrientes para a corrente sanguínea (Deeming, 2002). Sua composição é de aproximadamente 50\% de água, $15 \%$ de proteína, 
$33 \%$ de gordura e menos de $1 \%$ de carboidratos (Noble \& Cocchi, 1990), fatores como linhagem, tamanho do ovo, condições ambientais e a idade da ave podem influenciar na proporção de componentes do ovo (Santos et al., 2009). A composição lipídica da gema é majoritariamente de triacilgliceróis, fosfolipídios e colesterol livre, em menor proporção encontram-se os ácidos graxos livres. Sua fração lipídica é composta de ácido oleico (em maior quantidade) e dos ácidos palmítico e esteárico (juntos somam mais de um terço dos ácidos graxos) e também estão presentes frações substanciais de ácido linoleico e araquidônico (Noble \& Cocchi, 1990).

\subsubsection{Saco vitelino}

O saco vitelino é fonte primária de lipídios para o início do desenvolvimento dos tecidos embrionários (Meijerhof, 2009) e do intestino delgado (Noy \& Sklan, 1999), entre

outros órgãos. É absorvido pelo abdômen do embrião a partir dos 19 dias de incubação e na eclosão, constitui aproximadamente $15 \%$ do peso corporal do pinto de um dia. O resíduo do saco vitelino fornece nutrientes ao recém-nascido durante os primeiros dias de vida (Mikec et al., 2006; Meijerhof, 2009).

Cerca de $90 \%$ do total das necessidades energéticas do embrião durante a incubação são atendidas através da oxidação dos lipídios da gema (Noble \& Cocchi, 1990) e à eclosão, o peso do pinto é uma combinação do peso corporal com o peso do resíduo do saco vitelino (Meijerhof, 2009). Além disso, pintos privados de alimento após a eclosão usam aproximadamente $60 \%$ do resíduo do saco vitelino nas primeiras 48 h de vida (Noy \& Sklan, 1999).

\subsection{4 Ácidos graxos do saco vitelino}

Na gema, o colesterol predomina na forma livre é extensivamente esterificado na membrana do saco vitelino, indicando a importância desse processo na formação e estabilidade das lipoproteínas liberadas na circulação (Noble \& Cocchi, 1990). A alta atividade da acil-CoA-colesterol aciltransferase (ACAT) junto à baixa atividade da hidrolase dos ésteres de colesterol (colesterol esterase) e a atividade inibidora de proteínas do colesterol esterase são fatores essenciais para conversão do colesterol em ésteres de colesterol e são 
determinantes na transferência das taxas de lipídios da gema para o embrião (Shand et al., 1993).

Durante a incubação, espera-se que haja a diminuição da concentração do ácido esteárico com um aumento da concentração do ácido oléico. A enzima $\Delta 9$-dessaturase é responsável por converter o ácido esteárico em oléico (Noble \& Cocchi, 1990), que é um dos principais ácidos graxos presentes na gema durante esse período (Ding \& Lilburn, 1996). Sintetizado a partir do ácido linoléico, o ácido araquidônico é essencial para o desenvolvimento embrionário e o crescimento dos pintos (Speake \& Wood, 2005). Entre os dias 13 e 17 da incubação, a absorção de lipídios da gema é acompanhada por sua rápida acumulação na membrana do saco vitelino que no $17^{\circ}$ dia contém tantos lipídios quanto o conteúdo do saco vitelino (Figura 1.2). Pouco antes da eclosão, há perda rápida na quantidade dos lipídios da membrana. (Noble \& Cocchi, 1990). Segundo Noble \& Shand (1985), as maiores frações lipídicas da membrana do saco vitelino e fígado dos embriões entre 15 e 19 dias de incubação são as de ácido esteárico, oléico, linoléico e araquidônico. Após a eclosão, combustão total dos ácidos graxos produz glicose sem acúmulo de corpos cetônicos (Ohtsu et al., 2003).

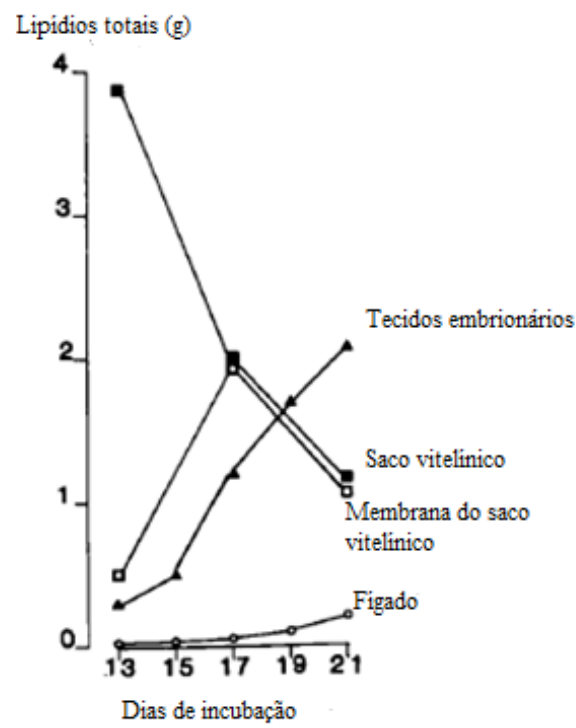

Figura 1.2 Movimento relativo dos lipídios do saco vitelino aos embriões de pintos via membrana do saco vitelino. Pesos totais dos lipídios do conteúdo total do saco vitelino, membrana do saco vitelino e tecidos embrionários durante a última semana de incubação (Adaptado de Noble \& Cocchi, 1990). 


\subsubsection{Oxidação lipídica}

A clivagem oxidativa de duplas ligações em ácidos insaturados produz aldeídos e ácidos caboxílicos de cadeia mais curta e, portanto, com maior volatilidade (Lehninger, 2002). A peroxidação dos lipídeos resulta em decréscimos no seu valor energético (Bertechini 2012), modificação das características físico-químicas, afeta o mecanismo de absorção das vitaminas lipossolúveis, além de oxidá-las. Quanto maior a insaturação, menor a estabilidade à oxidação (Butolo, 2002) que é catalisada por radicais livres de oxigênio (Butolo, 2002). A entrada de $\mathrm{O}_{2}$ na cadeia carbônica insaturada dos ácidos graxos reduz a capacidade de receber $\mathrm{O}_{2}$ durante a oxidação (Bertechini, 2012). Devido ao oxigênio molecular ser pouco reativo, esse processo ocorre somente em condições extremas como altas temperaturas e (ou) pressão (Butolo, 2002).

Os ovos possuem proteção quanto à oxidação lipídica devido à presença dos tocoferóis, carotenóides e a fosfovitina e também à estrutura da gema que é composta por lipoproteínas de muito baixa densidade (Oliveira \& Oliveira, 2013). Longos períodos de armazenamento favorecem o processo oxidativo dos ovos, principalmente em temperaturas mais altas (Pereira, 2009).

Peróxidos são compostos intermediários da oxidação dos ácidos graxos insaturados presentes nas gorduras e refere-se ao total de miliequivalentes de peróxidos/kg de gordura (Bertechini, 2012). Durante o processo de formação, há fixação de oxigênio sobre uma dupla ligação, formando-se o peróxido, muito instável, que se transforma em aldeído. As modificações secundárias influenciam no peso molecular, sabor e odor. Formam-se reações em cadeia que se propagam de molécula a molécula e todo novo peróxido formado libera energia para que os outros se formem. É necessária, portanto, pouca energia inicial para provocar a rancificação que prossegue o processo (Andriguetto et al., 2002). O início da peroxidação é lento com a entrada de $\mathrm{OH}^{-}$(forma ativa do oxigênio), e a propagação é rápida com a entrada de $\mathrm{O}_{2}$ molecular (Bertechini, 2012). Segundo Gomes (2011), a quantidade de peróxido não constitui um índice infalível das características de conservação, porém, indica até que ponto a oxidação progrediu.

Os compostos secundários são produzidos a partir dos primários, inclusive o malonaldeído (MDA), detectado através do teste de substâncias reativas com o ácido tiobarbitúrico, conhecido como TBARS. Este método baseia-se na reação de uma molécula de MDA com duas de ácido tiobarbitúrico (TBA), em meio ácido e sob altas temperaturas, 
formando um complexo vermelho, determinado por absorção no visível (532 nm) ou por fluorescência (Lima \& Abdalla, 2001). Porém, é importante estabelecer uma correlação entre os valores de TBARS com outros métodos, pois o MDA não é o único produto de oxidação dos lipídios que reage com o TBA quando o teor de MDA é baixo, outros aldeídos não provenientes do processo de degradação dos lipídios podem reagir com o TBA, os açúcares interferem sinergicamente na formação de TBARS, aumentando valores de oxidação. Por outro lado, o MDA pode não reagir com o TBA devido à sua complexação com proteínas, aminas e outros compostos (Fellenberg \& Speisky, 2006).

O índice de acidez também é importante na avaliação do estado de conservação lipídica. Um processo de decomposição, seja por hidrólise, oxidação ou fermentação, altera a concentração dos íons hidrogênio. A decomposição dos glicerídeos é acelerada por aquecimento e pela luz, sendo acompanhada pela formação de ácidos graxos livres (Instituto, 2008).

\subsection{Armazenamento de ovos incubáveis}

2.2.1 Condições ambientais ideais para o armazenamento, perda de peso do ovo durante o armazenamento e zero fisiológico

O tempo e a temperatura são fatores importantes que devem ser controlados durante o período de armazenamento para a manutenção da alta qualidade dos ovos (Jones et al., 2002). A umidade relativa do ambiente de armazenamento abaixo de 50\% diminui a viabilidade embrionária, pois há excessiva perda de água com alteração do $\mathrm{pH}$ interno e rápida liquefação do albúmen, assim, níveis ótimos estão situados entre 75 a 90\% (Macari et al., 2013).

Ovos armazenados sob condições inadequadas perdem água do albúmen para o ambiente e para a gema com consequente comprometimento embrionário e de eclodibilidade (Macari et al., 2013), o aumento no pH é responsável por diminuir a acidez do albúmen (Romanoff \& Romanoff, 1963) e é causado pela perda de $\mathrm{CO}_{2}$ através dos poros da casca . Quanto mais elevada a temperatura de armazenamento dos ovos, mais rápida é a sua perda para o ambiente, ocasionando a liquefação do albúmen (Karoui et al., 2006) e diminuição da altura do albúmen, devido às reações químicas envolvendo ácido carbônico $\left(\mathrm{H}_{2} \mathrm{CO}_{3}\right)$ que é responsável pelo sistema tampão do albúmen e após dissociação forma água e gás carbônico 
(Romanoff \& Romanoff, 1963). Consequentemente, ocorre o aumento de gradiente de pressão osmótica entre albúmen e gema com a entrada de água na gema, aumentando o seu alargamento e diminuindo a viscosidade o que libera e facilita a absorção de macromoléculas, glicose e íons essenciais do vitelo para o blastoderma, porém o processo deve ocorrer de maneira equilibrada, dentro de limites que dependem diretamente do tempo e temperatura de armazenamento para que não haja prejuízos ao desenvolvimento embrionário (Macari et al., 2013).

Santos et al. (2009) verificaram que a qualidade dos ovos é alterada em função da temperatura de conservação e período de armazenamento, pois os ovos mantidos em temperatura de refrigeração apresentaram menor perda de peso e melhores índices de percentagem de albúmen, gravidade específica e unidades Haugh quando comparados aos ovos conservados em temperatura ambiente. Barbosa et al. (2008) relataram maior perda de peso e também da qualidade interna nos ovos armazenados em temperatura ambiente mais alta e umidade mais baixa. Véras et al. (1999) perceberam que o peso dos ovos e as unidades Haugh eram modificados em função do tempo e do ambiente de armazenamento.

Fasenko et al. (2001) perceberam que ovos armazenados durante 4 e 14 dias tiveram perda de peso durante o armazenamento de $0,15 \%$ e $1,20 \%$. Reijrink et al. (2010) verificaram que ovos de matrizes entre 41 e 50 semanas armazenados sob temperatura média entre $16^{\circ}$ e $18^{\circ} \mathrm{C}$ durante 4 dias perderam $0,53 \%$ menos peso durante o armazenamento quando comparados com ovos armazenados por 14 dias ( $\mathrm{P}<0,001)$. Meijerhof \& Beek (1993) notaram que longos períodos de armazenamento em baixas temperaturas, a perda de água do ovo é de $0,05 \%$ ao dia.

O zero fisiológico é a interrupção do desenvolvimento do embrião através de temperaturas baixas no armazenamento dos ovos (Fasenko, 2007). Antes da postura, o desenvolvimento embrionário inicia-se no oviduto, com temperatura corporal da galinha entre $40^{\circ}$ e $41^{\circ} \mathrm{C}$. Após a postura, a temperatura ideal para armazenamento de ovos é abaixo de $21^{\circ} \mathrm{C}$, a fim de prevenir o crescimento bacteriano e paralisar o desenvolvimento do embrião, também conhecido como zero fisiológico. Durante o processo de incubação o desenvolvimento é retomado em temperaturas próximas de $37,5^{\circ} \mathrm{C}$ (Fasenko, 2007). 
2.2.2 Relação da idade da matriz, peso do ovo, eclodibilidade, peso e qualidade do pintinho

A qualidade do ovo declina à medida que a idade da matriz avança, de forma irreversível, segundo Oliveira \& Oliveira (2013). Há diferença no desenvolvimento inicial entre embriões provenientes de reprodutoras novas e velhas, como também se esses passam por armazenamento ou não. Ovos provenientes de reprodutoras mais velhas apresentam desenvolvimento precoce com relação às mais jovens com qualidade comprometida, principalmente com relação aos nutrientes da gema e são mais suscetíveis à contaminação (Macari et al., 2013). Poedeiras jovens apresentam melhor qualidade de albúmen quando comparadas com aves mais velhas. A qualidade do albúmen e a distância entre o blastoderma e a casca se mantêm constantes durante períodos maiores em aves novas (Santos et al., 2009).

$\mathrm{O}$ armazenamento de ovos por um a dois dias à $16^{\circ} \mathrm{C}$ e $79 \%$ de UR ou $21^{\circ} \mathrm{C}$ e 63\% de UR não alterou a mortalidade embrionária em ovos de matrizes jovens, porém, aumentou consideravelmente em ovos de matrizes velhas (Reis et al., 1997). Os autores concluíram que os efeitos das condições e a duração do armazenamento sobre a mortalidade embrionária variam de acordo com a idade da matriz e que a taxa de mortalidade é menor em ovos de matrizes mais velhas quando comparadas às mais jovens.

Willemsen et al. (2008) estudaram a relação entre idade e linhagem da matriz e peso e qualidade dos ovos e dos pintos e observaram que os pintos de matrizes mais novas eram mais leves do que as matrizes mais velhas. Os autores encontraram valores médios de peso corporal do pinto recém-eclodidos de $43 \mathrm{~g}$ para matrizes com 39 semanas da linhagem Cobb® e o mesmo peso médio foi encontrado para essa faixa etária em pintos de matrizes da linhagem Ross ${ }^{\circ} ; 45,9 \mathrm{~g}$ provenientes de matrizes com 42 semanas da linhagem Cobb® e 47,4g para matrizes com 53 semanas da linhagem Ross.

Barbosa et al. (2012) verificaram que a qualidade das cascas dos ovos de matrizes velhas é inferior aos de matrizes mais novas, o que pode justificar maiores perdas de peso dos ovos de matrizes mais velhas. Em seu estudo com matrizes Cobb® com 33 e 63 semanas verificaram que os ovos de matrizes com 33 semanas foram mais leves, e o número de poros por $\mathrm{cm}^{2}$ foi menor que o de ovos das aves mais velhas. Ovos de aves com 63 semanas apresentaram menor percentual de casca em relação ao peso do ovo, menor peso específico e menor resistência e espessura da casca. 
2.2.3 Metabolismo dos ácidos graxos durante o processo de incubação e influência do armazenamento

Mudanças no perfil de ácidos graxos da gema durante a incubação alteram o perfil das lipoproteínas na circulação sanguínea (Latour et al., 1998). Modificações quantitativas e qualitativas intensas ocorrem nas principais frações lipídicas de vários tecidos dos embriões de pintos durante a última semana do desenvolvimento embrionário. A parcela lipídica da gema é composta de $72 \%$ de triglicerídeos e $22 \%$ de fosfolipídios que são metabolizados e absorvidos a partir dos 14 dias de incubação (Noble \& Shand, 1985).

Latour et al. (2000) verificaram que durante a incubação, há diminuição acentuada nos fosfolipídios com altas concentrações dos ácidos graxos docosahexaenóico e esteárico, que causam o aumento da concentração dos ácidos oléico e palmítico. Em comparação com o conteúdo da gema, a membrana do saco vitelino aumenta a concentração de ácido araquidônico. Noble \& Shand (1985) demonstraram que a enzima $\Delta$ 9-dessaturase (conversora do ácido esteárico (18:0) em oléico (18:1)) aumenta durante os estágios iniciais da gema de forma específica.

As células do saco vitelino possuem diversas enzimas capazes de alterar os lipídios absorvidos para a circulação através de mecanismos de endocitose mediados por receptores (Herman et al., 2000; Powell et al., 2004) e absorvem as lipoproteínas de densidade muito baixa (VLDL) (Gonzales et al., 2013) via absorção direta e transporte da gema para o intestino delgado.

O processo de $\beta$-oxidação dos ácidos graxos é a principal fonte energética e nutricional do embrião (Speake et al. 1998), que absorve o conteúdo lipídico da gema durante a última semana de incubação. Ocorrem mudanças no conteúdo da membrana do saco vitelino, que aumenta consideravelmente a quantidade de lipídios totais entre os dias 15 e 17 de incubação com queda entre 17 e 19 dias (Noble \& Shand, 1985). No pós-eclosão, os ácidos graxos insaturados do saco vitelino são utilizados rapidamente durante os primeiros dias e no fígado, os ácidos graxos poli-insaturados diminuem cerca de 40 vezes (Latour et al., 2000).

Alguns estudos sugerem que quanto maior o tempo de armazenamento, maior deve ser o tempo de incubação (Fasenko et al., 2001; Brand et al., 2010) ou seja, os embriões necessitariam de mais horas dentro da incubadora para completar desenvolvimento, pois a viabilidade do embrião é dependente do tempo de armazenamento dos ovos (Brand et al., 2010). Reijrink et al. (2010) verificaram que pintos provenientes de ovos armazenados 
durante 4 dias eclodiram antes do que pintos provenientes de ovos armazenados durante 14 dias.

O crescimento inicial de embriões de ovos armazenados por longos períodos pode ser afetado, assim como o desenvolvimento em si, que ocorre mais lentamente quando comparado com ovos armazenados em curtos períodos (Fasenko, 2007). A nível celular, longos períodos de armazenamento influenciam no desenvolvimento e metabolismo do embrião, pois induzem a morte celular resultando em alta mortalidade embrionária e, consequentemente, baixa eclodibilidade (Fasenko et al., 2001; Fasenko, 2007). Reijrink et al. (2010) citam que o aumento da mortalidade celular durante o armazenamento, pode afetar a viabilidade do embrião que, em determinado estágio da diferenciação celular, necessita de um número mínimo de células embrionárias viáveis para a continuidade do desenvolvimento embrionário normal, caso contrário, ocorrerá morte embrionária nos primeiros dias de incubação.

A fim de minimizar os danos causados por longos períodos de armazenamento e reduzir a mortalidade embrionária, pode-se aplicar a pré-incubação ou incubação préestocagem, procedimento que consiste em um pré-aquecimento dos ovos acima do zero fisiológico $\left(37,8^{\circ} \mathrm{C}\right)$ anterior ao processo de armazenamento prolongado visando aumentar o número de células embrionárias viáveis (de 40.000 - 60.000 para cerca de 80.000), segundo Tierzucht, (2011). Fasenko et al. (2001) verificaram aumento do número de células embrionárias viáveis, sem aumento significativo de necrose celular ou células apoptóticas, com pouca ou nenhuma alteração do $\mathrm{pH}$ da gema e do albúmen. Os mesmos autores citam que os melhores resultados são encontrados com 12 horas de pré-incubação para ovos armazenados durante 4 dias e 18 horas para armazenamento de 14 dias.

\subsubsection{Armazenamento, mortalidade embrionária e qualidade do pinto}

No momento da oviposição, os ovos contém alta concentração de $\mathrm{CO}_{2}$, que começa a ser eliminado após a postura, aumentando o $\mathrm{pH}$ do albúmen de 7,6 para 8,5 - 9,0 em decorrência, principalmente, ao período de armazenamento dos ovos (Macari et al., 2013) e acima de 7 dias, há prejuízo à eclodibilidade (Brand et al., 2010) e à qualidade do pintinho, além disso, a viabilidade do embrião é dependente do tempo de armazenamento dos ovos (Brand et al., 2010). Ovos incubáveis são comumente armazenados antes da incubação durante 3 a 7 dias (Fasenko et al., 2001), melhores índices de eclosão ocorrem quando ovos 
são submetidos a períodos entre 2 e 5 dias de armazenamento (Macari et al., 2013). O período de armazenamento mínimo deve ser respeitado para que o embrião adapte-se ao ambiente do ovo pós-postura.

Os parâmetros de avaliação da mortalidade embrionária são padronizados para que haja melhor avaliação dos índices de incubatório. Segundo Fasenko (2007) a mortalidade embrionária pode ser avaliada em três períodos distintos, entre 0 a 7 dias de incubação (mortalidade inicial), 8 a 14 dias (mortalidade intermediaria) ou entre 15 a 21 dias de incubação (mortalidade tardia).

Quanto mais tempo os ovos são armazenados, piores são os índices de incubação, perde-se $1 \%$ de eclosão para cada dia acima de 5 dias de armazenamento e 1,5\% após o oitavo ao décimo dia (Cobb, 2013) além de uma correlação negativa entre período de armazenamento e a altura do albúmen (Macari et al., 2013). Isso porque ocorre aumento da mortalidade celular, assim, ao tentar reativar o processo de desenvolvimento através da incubação, os embriões apresentam poucas células viáveis e capazes de sobreviver ao processo, gerando aumento da mortalidade embrionária inicial. Da mesma forma, aumenta a mortalidade tardia que ocorre durante o último terço do período de incubação (Fasenko et al., 2001).

Fasenko et al. (2001) avaliaram embriões provenientes de ovos armazenados durante períodos de 4 e 14 dias. A mortalidade embrionária inicial e final aumentou com o aumento do tempo de armazenamento. A mortalidade embrionária aos 4 dias de armazenamento foi de $10,3 \%$ e de $27,8 \%$ para ovos armazenados durante 14 dias, a eclodibilidade foi de $89,7 \%$ e de $72,2 \%$, respectivamente.

A qualidade do pinto recém-nascido é determinante para sua sobrevivência, crescimento e saúde, sendo os principais indicadores: peso corporal, tamanho e massa corporal livre de gema (Willemsen et al., 2008). O primeiro parâmetro é importante na perspectiva do peso final do frango (Sklan et al., 2003; Meijerhof, 2006). Nos incubatórios comerciais, os parâmetros físicos de avaliação dos pintos são utilizados para classificar os pintos (Reijrink et al., 2010), mas outros parâmetros são importantes para avaliar a qualidade do pintinho, como o peso corporal livre de gema (Sahan, 2014).

Os efeitos negativos do armazenamento prolongado na qualidade dos pintinhos foram verificados por Tona et al. (2003) através de parâmetros físicos de avaliação no dia do nascimento, tais como aparência, atividade e qualidade do umbigo (Willemsen et al., 2008). 
2.3 Ácido linoléico conjugado (CLA) na produção de pintos de corte

2.3.1 Principais isômeros do ácido linoléico $(\omega 6)$ e estrutura molecular dos cis9 , trans-11 e trans- 10 , cis- 12

O ácido linoléico (18:2n-6) é um ácido graxo insaturado com 18 carbonos e duas duplas ligações nos C9 e C12 nas posições cis/cis. O ácido linoléico conjugado (CLA) é uma mistura de isómeros geométricos e posicionais com ligações duplas situadas no $\Delta[9,11]$, [10,12], [8,10], [7,9] e [11,13] (Kramer et al., 1998) encontrado principalmente na carne e produtos lácteos de ruminantes (EFSA, 2016), como resultado do processo de biohidrogenação enzimática do ácido linoleico conduzido pelas bactérias ruminais desses animais (Banni, 2002). As duplas ligações do CLA são conjugadas e separadas por uma ligação simples (Fig.1.3).

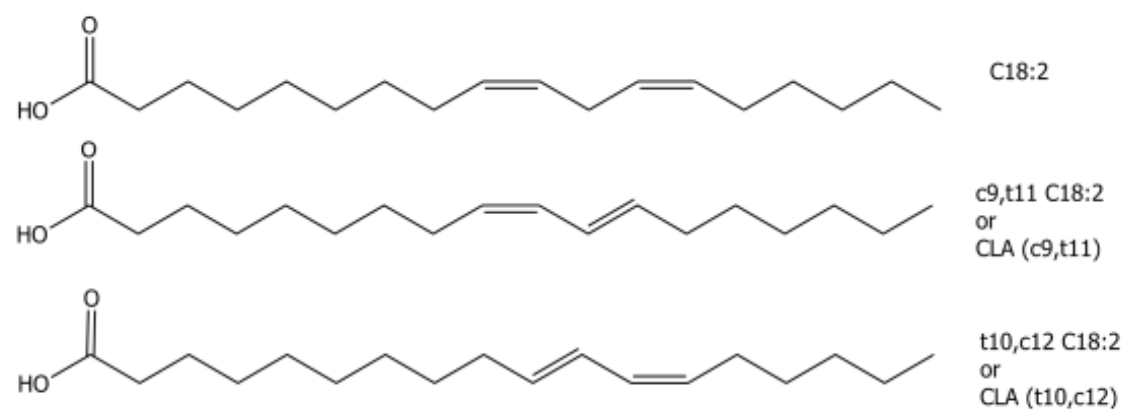

Figura 1.3 Estrutura do ácido linoléico e suas principais conjugações c9,t11 C18:2 e t10,c12 C18:2 (Fonte: EFSA, 2016).

\subsubsection{Fontes de CLA}

O CLA é encontrado principalmente em alimentos derivados de animais ruminantes, sendo gerados, na maioria das vezes, a partir do acido linoléico dietético (EFSA, 2016). Na carne dos ruminantes é possível encontrar 80-90\% e 3-5\% dos isômeros cis-9, trans-11 e trans-10, cis-12, respectivamente (Khanal \& Dhiman, 2004). Também o nível de gordura da carne determina a concentração do CLA, uma vez que carnes ricas em gorduras têm maiores concentrações, cerca de 9,60-13,1 mg/g de gordura, enquanto a carne magra apresenta 0,06-0,43 mg /g de gordura do isômero cis-9, trans-11 (Fogerty et al., 1988). 
Por outro lado, as carnes de animais não ruminantes contêm concentrações mais baixas de CLA, sendo que carne de suínos e de frangos podem conter 0,9 e 0,6 mg /g de gordura, respectivamente, e os óleos de peixes contém concentrações ainda mais baixas de CLA (Chin et al., 1992). Os óleos vegetais brutos podem conter quantidades muito baixas de CLA, como o óleo de canola, que contém $0,1 \mathrm{mg} / \mathrm{g}$ de gordura e o óleo de coco ou de girassol, que contém 0,7 mg / g de gordura (Evans et al., 2002).

\subsubsection{Características e propriedades dos isômeros de CLA}

Algumas das propriedades biológicas mais importantes são atividade anticancerígena, efeitos na redução da gordura corporal, atividade anti-aterogênica e aumento da função imunológica (Aydin \& Cook, 2009).

Os isômeros biologicamente relevantes são c9, t11 (C18:2) e t10, c12 (C18:2). (EFSA, 2016; Aydin \& Cook, 2009). O isômero cis-9, trans-11 demonstrou desenvolver fatores de crescimento, enquanto o isômero trans-10, cis-12 desempenha papel no metabolismo de gorduras, diminuindo a atividade da estearoil-CoA dessaturase inibindo o processo de dessaturação dos ácidos graxos saturados, aumentando sua quantidade (Aydin \& Cook, 2009). É provável que esta enzima também possa ser responsável por modificar o transporte de alguns nutrientes essenciais ao desenvolvimento embrionário no ovo (Leone et al., 2009).

O CLA é um eficiente agente redutor de gordura corporal causando mudanças metabólicas pelo aumento do gasto de energia, redução de deposição de gordura corporal, a estimulação do processo de apoptose em pré-adipócitos e um aumento na lipólise e $\beta$ oxidação no tecido muscular (Park \& Pariza, 2007), além de afetar o metabolismo lipídico em diversos tecidos, incluindo fígado, músculo e tecido adiposo, de diferentes maneiras (Evans et al., 2002).

\subsubsection{CLA dietético na produção de ovos incubáveis}

O perfil de ácidos graxos das gemas está diretamente relacionado com a composição de ácidos graxos da dieta das matrizes, porém, os ácidos graxos saturados são mais resistentes às manipulações dietéticas. Com a inclusão do CLA, ocorre o aumento do 
nível de ácidos graxos saturados nas gemas, que pode estar relacionado à inibição da $\Delta 9$ dessaturase no fígado (Suksombat et al., 2006), enzima responsável pela dessaturação do $\Delta 9$ cis em diversos ácidos graxos insaturados (Cohen et al., 2002).O ácido linoléico (ômega 6) é constituinte dos fosfolipídios e estéres de colesterol e sua principal função biológica é atuar como precursor das prostaglandinas $(\mathrm{PGF} 2 \alpha)$ e tromboxanos. A PGF2 $\alpha$ age na contração uterina e, consequentemente, na expulsão do ovo, facilita a oviposição ao relaxar a musculatura vaginal das matrizes (Macari et al., 2002).

O consumo de ração está positivamente relacionado ao peso do ovo, ganho de peso vivo e peso da gema, conforme citado por Suksombat et al. (2006) que verificaram que a inclusão de CLA diminuiu o consumo de ração das matrizes e, consequentemente, a produção de ovos, uma vez que as galinhas suplementadas com 4, 2 e 1\% de CLA produziram menos ovos. A dieta com 4\% de CLA produziu ovos mais leves, gemas menores e albúmen mais leve, mas com Unidades Haugh e espessura de cascas semelhantes. Jones et al. (2000) relataram que a produção de ovos diminuiu significativamente, mesmo em níveis baixos de inclusão de CLA na dieta como 0,5 e 1,0\% .

A inclusão do CLA nas dietas também pode afetar a composição de ácidos graxos nas gemas e causar prejuízos à sobrevivência embrionária. Dietas de matrizes com CLA aumentaram os níveis de CLA e ácidos graxos saturados nas gemas e diminuíram os níveis de ácidos graxos monoinsaturados (Aydin \& Cook, 2009). Os principais isômeros de CLA presentes na dieta foram transferidos para a fração lipídica de gema de formas distintas, o isômero trans-10, cis-12 foi incorporado de forma menos eficiente em comparação com o cis-9,trans-11 (Aydin \& Cook, 2009). Kramer et al. (1998) sugerem que o isômero trans-10, cis-12 pode ser metabolizado mais rápido ou absorvido seletivamente.

Aydin et al. (2001) verificaram a movimentação mineral (Ca, Mg, Fe, $\mathrm{Na}$ e Zn) entre gema e albúmen através dos gradientes de concentração em ovos de matrizes suplementadas com CLA e armazenadas a $15^{\circ} \mathrm{C}$ durante 10 semanas, porém o mesmo não foi verificado no grupo sem CLA. Leone et al. (2009) não encontraram efeitos da adição de 0,5\% de CLA dietético sobre a eclodibilidade de ovos armazenados por 24 e 48h. Porém, verificaram movimentação mineral entre a gema e o albúmen de ovos armazenados por 48h.

Suksombat et al. (2006) suplementaram matrizes de Hisex Brown de 27 semanas de idade com níveis crescentes de CLA $(0,1,2,3$, e 4\%). O maior percentual de suplementação reduziu o tamanho dos ovos, gema e albúmen. Houve alteração na cor, aumentou a quantidade de ácidos graxos saturados nas gemas, com diminuição dos ácidos graxos poli-insaturados e monoinsaturados, no entanto, houve aumento da quantidade do 
CLA nas gemas. A composição de ácidos graxos na dieta afetou o perfil de ácidos graxos da gema, mas a concentração dos isômeros do CLA nas gemas não foi proporcional ao administrado nas dietas.

2.3.5 CLA dietético, embriogênese e mortalidade da progênie de matrizes pesadas

Os efeitos da suplementação do CLA sobre a mortalidade embrionária foram avaliados por Aydin \& Cook (2009) e Muma et al. (2006),que verificaram que a inclusão de 0,5\% de CLA provocou $100 \%$ de mortalidade embrionária em ovos férteis. No primeiro estudo, a mortalidade embrionária foi detectada aos 6 dias de incubação, já no segundo, foi detectada aos 11 dias após o início da incubação. Leone et al. (2009) notaram que a partir dos 4 dias de fornecimento do CLA houve queda na eclodibilidade, esse também foi o prazo para que o CLA mudasse o perfil de ácidos graxos do ovo e, quanto mais tempo as galinhas foram alimentadas com CLA, mais cedo os embriões morreram durante a incubação. Aydin et al. (2001) mostraram que após 3 dias do início da suplementação com CLA houve diminuição das taxas de eclosão e depois de 7 dias da suplementação de CLA houve a mortalidade de $100 \%$ dos ovos férteis.

A adição de óleos ricos em acidos graxos poliinsaturados e monoinsaturados à suplementação de CLA diminui os efeitos deletérios do CLA na eclodibilidade (Aydin et al., 2001; Aydin \& Cook, 2004, 2009; Muma et al., 2006). Aydin \& Cook (2009) conseguiram evitar os efeitos do CLA sobre a mortalidade embrionária com a inclusão do óleo de canola (rico em C18:3(n-3)), mesmo com maiores níveis de inclusão de CLA (4,0 e 2,0\% respectivamente).A quantidade de CLA nos ovos aumentou 44 vezes quando comparados aos ovos sem CLA, porém não houve efeito adverso sobre a mortalidade embrionária, pois o óleo de canola reestabeleu a relação entre C18:0 e C18:1(n-9). Da mesma forma, Muma et al. (2006) relatam aumento progressivo de eclodibilidade com inclusão de óleo de soja nas dietas.

A mortalidade embrionária observada nos ovos férteis de galinhas alimentadas com CLA não parece estar associada aos diferentes níveis de CLA nas dietas ou gemas dos ovos, mas sim aos níveis mais elevados de ácidos graxos saturados liberados pelo metabolismo do CLA dietético e à razão entre saturação/insaturação, uma vez que a taxa de eclosão aumenta com a inclusão de uma fonte de ácidos graxos insaturada à dieta (Aydin, 
2000; Aydin \& Cook, 2009; Leone et al., 2009). Para Leone et al. (2009), o CLA na nutrição das matrizes diminuiu a eclodibilidade independente das condições e períodos de armazenamento de ovos. Aydin \& Cook (2009) observaram que o CLA suplementado na dieta materna não é diretamente tóxico para o desenvolvimento embrionário, mas causa mortalidade embrionária por alterar a composição dos ácidos graxos da gema dos ovos férteis. Watkins et al. (2003) observaram que o CLA causou aumento dos níveis de ácidos graxos saturados na membrana do saco vitelino, o que pode ter aumentado a permeabilidade da membrana e, consequentemente, os índices de mortalidade, devido à inibição da $\Delta 9$ dessaturase no fígado dos embriões (Suksombat et al., 2006).

2.3.6 Peroxidação, capacidade antioxidante dos tecidos embrionários dos pintos e efeito antioxidante do CLA dietético

Os tecidos do embrião possuem alto grau de insaturação, quando comparados ao conteúdo lipídico da gema. Os ácidos graxos monoinsaturados são relativamente resistentes à peroxidação, que aumenta com o aumento do nível de insaturação. O cérebro do embrião é rico em ácidos graxos poli-insaturados, principalmente os 20:4n-6 e 22:6n-3, em contraste, o fígado possui maior quantidade de monoinsaturados como 18:1n-9 e 18:2n-6 (Ko et al., 2004).

A configuração lipídica cerebral unida às altas taxas metabólicas e utilização de $\mathrm{CO}_{2}$ geram grande risco à peroxidação lipídica, principalmente no início da incubação e recém-eclosão, período em que o pintinho está exposto ao $\mathrm{O}_{2}$ atmosférico e também possui alta taxa metabólica, podendo causar danos irreversíveis à função cerebral. O sistema antioxidante eficiente com a combinação $\alpha$-tocoferol e ácido ascórbico protege o embrião contra a peroxidação de forma eficiente (Surai et al., 1996).

Ko et al. (2004) avaliaram a peroxidação lipídica dos tecidos de frangos suplementados com CLA até a idade de abate, aos 35 dias, alimentados com dieta sem CLA, ou com suplementação de 1,5\% CLA ou com suplementação de 0,75\% de CLA e 0,75\% de óleo de soja, a fim de determinar como a dieta com CLA poderia afetar a habilidade antioxidante do intestino delgado e fígado dos frangos. Não foi verificada diferença nos níveis de malonaldeído (através da metodologia de TBARS) nos microssomos dos intestinos nem no fígado, ou seja, não houve atividade antioxidante. 
Kim et al. (2005), em estudo realizado com ratos suplementados com 1,5\% de CLA, encontraram redução na concentração hepática de TBARS, e também na atividade das enzimas antioxidantes glutationa peroxidase e superóxido dismutase, comprovando a atividade antioxidante dos isômeros. O CLA dietético induziu o aumento de ácidos graxos saturados e a diminuição dos poli-insaturados nos tecidos de aves (Leone et al., 2009; Audyn \& Cook, 2009), o que pode ter levado à diminuição da formação dos produtos de peroxidação lipídica, como o malonaldeído (Joo et al., 2002) que são menos suscetíveis que o ácido linoléico (Santos-Zago et al., 2006).

No estudo de Ko et al. (2004), a dieta com 1,5\% de CLA não afetou a atividade específica das enzimas superperóxido dismutase, glutationa peroxidase e a glutationa $\mathrm{S}$ transferase, porém um aumento significativo na atividade especifica da catalase foi observada nas aves, além de uma alteração no metabolismo lipídico, diminuindo o conteúdo lipídico hepático. Este último foi, em parte, responsável pelo metabolismo antioxidante, uma vez que afetou a atividade da catalase, pode ter induzido ao aumento do gasto energético na oxidação lipídica e redução da gordura da carcaça, o que explica a redução lipídica do fígado, porém, não foi capaz de alterar a atividade das outras enzimas antioxidantes.

A resposta do CLA como antioxidante do sistema de defesa dos tecidos é controversa. Alguns autores (Du et al.,2001; Joo et al., 2002) citam que CLA reduziu a peroxidação lipídica e preservou a cor das carcaças de frangos e suínos. Porém, a capacidade antioxidante muda de acordo com a dieta basal, a composição do CLA e a espécie (Stangle, 2000). A capacidade do CLA de diminuir a peroxidação lipídica pode ser associada à sua capacidade de afetar o sistema de defesa antioxidante (Ko et al., 2004). Leung \& Liu (2000) relataram que o isômero t-10, c-12 mostrou maior capacidade de eliminação de radicais livres com propriedades antioxidantes e o c-9, t-11 pró-oxidantes, o que explica a sua atividade anticancerígena (Basu et al., 2000; Kilian et al., 2002).

2.3.7 Metabolismo e efeitos do CLA dietético nas matrizes pesadas e na progênie

Sabe-se que os ácidos graxos insaturados do saco vitelino e do fígado são utilizados rapidamente durante os primeiros dias pós-eclosão (Latour et al., 2000). Em estudo realizado por Latour et al. (2000) verificaram que a suplementação com CLA provocou pouca mudança no peso do saco vitelino até dois dias de idade devido ao sistema de remoção dos 
lipídios do saco vitelino ser prejudicado pela modificação na $\Delta 9$-dessaturase, gerando sacos vitelinos menores ao nascimento, porém, o grupo sem CLA adaptou-se rapidamente até seis dias de idade.

Suksombat et al. (2007) através da suplementação de 1,5\% de CLA para matrizes pesadas, notaram menor consumo de ração diário, sem perda de peso corporal, porém, houve diminuição do peso dos ovos e dos pintos, além de maior peso de fígado ao nascimento. Latour et al. (2000) notaram que pós quatro meses de suplementação com CLA (1g de CLA a cada 2 dias), as matrizes exibiram aumento do peso corporal e do tamanho do ovo, porém não houve diferença no consumo alimentar. Não foram observados aumentos da mortalidade embrionária e nem do peso do pinto aos seis dias de idade, porém os pintos provenientes de matrizes que consumiram CLA apresentaram aumento dos ácidos graxos 18:3n-3 e 22:1n-9 e diminuição dos 20:3n-6 e 22:5n-3 no fígado. Nas gemas, o 18:0 foi maior do que no grupo sem CLA. 
CAPÍTULO 2 
RESUMO

INCLUSÃO DO CLA NA DIETA DE MATRIZES DE CORTE E TEMPOS DE ARMAZENAMENTO DE OVOS INCUBÁVEIS SOBRE O RENDIMENTO DA INCUBAÇÃO E QUALIDADE DA PROGÊNIE

\author{
DISCENTE: PRISCILA SOARES SILVÉRIO ${ }^{1}$ \\ ORIENTADORA: Prof ${ }^{\mathrm{a}}$. Dr ${ }^{\mathrm{a}}$. ALINE MONDINI CALIL RACANICCI ${ }^{1}$ \\ ${ }^{1}$ Universidade de Brasília - UNB
}

Foi conduzido um experimento a fim de avaliar o efeito da inclusão dos isômeros cis-9, trans11 e trans-10, cis-12 de ácido linoléico conjugado (CLA) na dieta de matrizes pesadas e do armazenamento dos ovos incubáveis durante três, seis e nove dias na sala de ovos do incubatório. Os tratamentos foram definidos pelas dietas (com inclusão de 0,023\% de CLA ou sem CLA) oferecidas para um total de 22.000 matrizes pesadas da linhagem Cobb® em fase de postura com idades entre 58 e 60 semanas e os tempos de armazenamento (três, seis e nove dias). Foram utilizados 6.912 ovos distribuídos em um delineamento inteiramente casualisado em um esquema fatorial 2x3 (com ou sem inclusão de CLA nas dietas das matrizes $x 3$ períodos de armazenamento). Foram amostrados 30 ovos por tratamento Para a avaliação dos parâmetros físicos de qualidade como: peso, altura, porcentagem, $\mathrm{pH}$ de gema e albumen, proporção gema:albúmen, diâmetro e índice de gema, Unidade Haugh, peso, espessura e 
porcentagem de cascas, composição centesimal e oxidação dos lipídios da gema usando TBARS (substâncias reativas ao ácido tiobarbitúrico), índice de peróxidos e acidez. Os dados obtidos foram analisados adotando um modelo misto, com efeito fixo para os tratamentos e aleatórios para os períodos de armazenamento e as médias foram comparadas pelo teste de Tukey com significância de 5\%. Na primeira fase foi observado que a progressão dos tempos de armazenamento afetou negativamente $(\mathrm{P}<0.05)$ a qualidade física e a composição centesimal dos ovos incubáveis, porém a inclusão do CLA na dieta das matrizes minimizou esses efeitos, especialmente em ovos armazenados durante nove dias.

Palavras-chave: CLA, armazenamento, qualidade dos ovos incubáveis, qualidade física de ovos incubáveis; composição centesimal de ovos incubáveis. 


\begin{abstract}
INCLUSION OF CLAIN BROILER BREEDERS HENS FED DIET AND TIMES OF HATCHING EGGS STORAGE ON INCUBATION YIELD AND QUALITY OF PROGENY
\end{abstract}

\author{
GRADUATE STUDENT: PRISCILA SOARES SILVÉRIO ${ }^{1}$ \\ ADVISOR: PhD. Dr ${ }^{\mathrm{a}}$. ALINE MONDINI CALIL RACANICCI ${ }^{1}$ \\ ${ }^{1}$ University of Brasília - UNB
}

An experiment were conducted to evaluate the effect of the inclusion of cis-9, trans-11 and trans-10, cis-12 conjugated linoleic acid isomers (CLA) in the diet of broiler breeders and storage of hatching eggs during three, six and nine days in the hatchery egg room. The treatments were defined by breeders diets (with the inclusion of 0,023\% CLA or without CLA) offered total of 22.000 broiler breeders Cobb® 58 and 60 weeks old during laying phase and the storage periods (three, six nine days). Were used 6.912 eggs were distributed for each storage period at the eggs room in a completely randomized in a $2 \times 3$ factorial (with or without the inclusion of CLA in the diets x 3 storage periods) 30 eggs per treatment were used to perform physical parameters of egg quality such as weight, height, percentage, $\mathrm{pH}$ yolk and albumen, yolk ratio: albumen, diameter and yolk index, Haugh unit, weight, 
thickness and percentage of eggshell, chemical composition and oxidation yolk lipids using TBARS (thiobarbituric acid reactive substances), peroxide value and acidity. Data were analyzed using a mixed model with fixed effects for treatment and random to storage periods and the averages were compared by Tukey test (5\% significance). In the first phase it was observed that the progression of storage time negatively affected $(\mathrm{P}<0.05)$ the physical quality and chemical composition of hatching eggs, as expected, however, the dietary CLA minimized these effects, particularly for nine days of storage. In the second phase it was observed that longer storage periods damaged the parameters of hatchability and quality of the chicks, however, dietary CLA showed positive effects on eggs stored for nine days, and reduced oxidative damage to lipids during the storage process.

Keywords: CLA, storage, quality of hatching eggs, physical quality of hatching eggs; proximate composition of hatching eggs. 


\section{INTRODUÇÃO}

$\mathrm{O}$ aumento do período de armazenamento, independente da temperatura de conservação, altera a qualidade dos ovos, ocasionando sua perda de peso e reduções na gravidade específica, nas unidades Haugh (Santos, 2009), através da perda de $\mathrm{CO}_{2}$ pelos poros da casca dos ovos armazenados, aumenta o pH, causa a liquefação do albúmen denso (Karoui et al., 2006) e consequentemente, reduz a altura do albúmen que é causada pela proteólise da ovomucina, pela clivagem das pontes de dissulfitos e pelas interações entre $\alpha$ e $\beta$ ovomucinas (Stevens, 1996), devido às às reações químicas envolvendo ácido carbônico $\left(\mathrm{H}_{2} \mathrm{CO}_{3}\right)$ que possui ação tamponante sobre o albúmen (Romanoff \& Romanoff, 1963).

Quanto mais tempo os ovos são armazenados, piores são os índices de incubação (Cobb, 2013), aumenta a mortalidade embrionária tardia que ocorre durante o último terço do período de incubação (Fasenko et al., 2001) e também afeta a qualidade dos pintinhos (Tona et al., 2003)

O CLA dietético possui propriedade antioxidante (Stangle, 2000; Du et al., 2001; Joo et al., 2002; Ko et al., 2004) e pode ser uma alternativa para ovos que necessitem passar por armazenamento prolongado, porém o perfil de ácidos graxos da gema é facilmente alterado pela quantidade e tipo de gorduras incluídas na dieta das matrizes (Noble \& Cocchi, 1990; Latour et al., 1998).

O objetivo deste estudo foi avaliar os efeitos da adição do ácido linoléico conjugado (CLA) nas dietas de matrizes pesadas e do tempo de armazenamento refrigerado na sala de ovos nos aspectos relacionados à qualidade física e composição centesimal do ovo incubável. 


\section{MATERIAL E MÉTODOS}

O protocolo experimental foi previamente aprovado pela Comissão de Ética no Uso de Animais da Universidade de Brasília (CEUA-UnB) sob o número UnBDoc 62528/2015, de acordo com os Princípios Éticos Para o Uso de Animais Experimentais da Sociedade Brasileira de Ciência em Animais de Laboratório (SBCAL/COBEA).

\subsection{Local e período de coleta dos ovos}

Os experimentos foram realizados em granjas de matrizes e em incubatório comercial localizado na região do Recanto das Emas, Distrito Federal, no período de 20 de abril a 19 de maio de 2015 .

As primeiras coletas de ovos ocorreram em 20 de abril de 2015 seguidas pelas datas de 23 e 26 de abril de 2015 e corresponderam, respectivamente, aos ovos armazenados por nove, seis e três dias.

\subsection{Manejo nutricional}

Foram utilizadas 22.000 matrizes pesadas da linhagem Cobb® em fase de postura com idades entre 58 e 60 semanas, sendo distribuídas igualmente entre os dois tratamentos (com CLA e sem CLA) em dois galpões distintos. As matrizes receberam ração (Tabela 2.1) à vontade formulada de acordo com as recomendações de Rostagno et al. (2011) 
e suplementadas ou não com $0,0235 \%$ de ácido linoléico conjugado (CLA), o que correspondeu à inclusão de $0,042 \%$ do produto comercial Lutalin®. O produto comercial é composto de $56 \%$ de metil ésteres de CLA (C18:2), 28\% do isômero cis-9, trans-11 e $28 \%$ do isômero trans-10, cis-12, segundo informações do fabricante (BASF). O nível de inclusão do CLA foi assim determinado com o intuito de evitar os efeitos deletérios do CLA sobre a mortalidade embrionária relatados anteriormente (Muma et al., 2006; Aydin \& Cook, 2009).

O fornecimento das rações experimentais teve início 21 dias antes da primeira coleta de ovos, em 29 de março de 2015 a fim de garantir a incorporação do CLA aos ovos.

Tabela 2.1 Composição percentual e calculada das rações experimentais

\begin{tabular}{|c|c|c|}
\hline \multirow[b]{2}{*}{ Ingredientes } & Sem CLA & Com CLA \\
\hline & \multicolumn{2}{|c|}{$\%$} \\
\hline Milho $7,88 \%$ PB & 68,179 & 68,128 \\
\hline Farelo de soja $45,5 \% \mathrm{~PB}$ & 17,416 & 17,425 \\
\hline Calcário 38\% & 7,876 & 7,876 \\
\hline Caulim & 4,000 & 4,000 \\
\hline Farinha de carne e ossos $43 \% \mathrm{~PB}$ & 1,500 & 1,500 \\
\hline Sal comum & 0,223 & 0,223 \\
\hline Fosfato bicálcico & 0,200 & 0,200 \\
\hline Bicarbonato de Sódio & 0,150 & 0,150 \\
\hline Suplemento mineral ${ }^{1}$ & 0,150 & 0,150 \\
\hline Suplemento vitamínico ${ }^{2}$ & 0,100 & 0,100 \\
\hline Colina $60 \%$ & 0,082 & 0,082 \\
\hline DL-metionina $88 \%$ & 0,080 & 0,080 \\
\hline L-Treonina $98 \%$ & 0,030 & 0,030 \\
\hline Antioxidantes $^{3}$ & 0,016 & 0,016 \\
\hline CLA $^{4}$ & - & 0,042 \\
\hline Enzima $^{5}$ & 0,003 & 0,003 \\
\hline \multicolumn{3}{|c|}{ Composição calculada } \\
\hline Energia metabolizável (Kcal/kg) & 2736 & 2734 \\
\hline Proteína bruta $(\%)$ & 13,90 & 13,90 \\
\hline Lisina digestível (\%) & 0,60 & 0,60 \\
\hline Metionina + cistina (\%) & 0,47 & 0,46 \\
\hline Treonina digestível (\%) & 0,50 & 0,50 \\
\hline Cálcio (\%) & 3,29 & 3,29 \\
\hline Fósforo disponível (\%) & 0,20 & 0,20 \\
\hline Sódio $(\%)$ & 0,34 & 0,34 \\
\hline \multicolumn{3}{|c|}{$\begin{array}{l}{ }^{1} \text { Suplemento mineral - níveis de garantia por quilograma de produto: Manganês } 80.000 \mathrm{mg} \text {, Zinco } 70.000 \mathrm{mg} \text {, } \\
\text { Ferro } 40.000 \mathrm{mg} \text {, Cobre } 8.000 \mathrm{mg} \text {, Iodo } 1.000 \mathrm{mg} .{ }^{2} \text { Suplemento vitamínico - níveis de garantia por quilograma } \\
\text { do produto: vitamina E } 110.000 \mathrm{mg} \text {, vitamina A } 14.000 \text { UI, vitamina D3 } 3.000 \text { UI, vitamina K3 } 6.000 \mathrm{mg} \text {, } \\
\text { vitamina B1 } 3.000 \mathrm{mg} \text {, vitamina B2 } 12.000 \mathrm{mg} \text {, vitamina B6 } 6.000 \mathrm{mg} \text {, vitamina B12 } 30 \mathrm{mg} \text {, niacina } 60.000 \mathrm{mg} \text {, } \\
\text { ácido pantotênico } 20.000 \mathrm{mg} \text {, ácido fólico } 4.000 \mathrm{mg} \text {, biotina } 300 \mathrm{mg} \text {. }{ }^{3} \text { Etoxiquim } 66,6 \% \text {, BHA } 99 \% \text { e Ácido } \\
\left.\text { cítrico } 99,5 \% ;{ }^{4} \mathrm{CLA} \text { (Lutalinß); }{ }^{5} \text { Enzima fitase (Natuphos } ® 10.000\right) \text {. }\end{array}$} \\
\hline
\end{tabular}




\subsection{Tratamentos experimentais}

Os ovos incubáveis com ou sem inclusão de CLA foram também submetidos a diferentes tempos de armazenamento na sala de ovos do incubatório, conforme abaixo:

- $\quad$ Ovos de matrizes alimentadas com ração suplementada com CLA e armazenados por três dias;

- $\quad$ Ovos de matrizes alimentadas com ração controle (sem suplementação de CLA) e armazenados por três dias;

- $\quad$ Ovos de matrizes alimentadas com ração suplementada com CLA e armazenados por seis dias;

- $\quad$ Ovos de matrizes alimentadas com ração controle (sem suplementação de CLA) e armazenados por seis dias;

- Ovos de matrizes alimentadas com ração suplementada com CLA e armazenados por nove dias;

- $\quad$ Ovos de matrizes alimentadas com ração controle (sem suplementação de CLA) e armazenados por nove dias.

\subsection{Classificação e armazenamento dos ovos incubáveis}

Os ovos provenientes das granjas de matrizes coletados nas datas informadas no item 4.1 foram separados conforme os tratamentos nutricionais (inclusão ou não de CLA) e classificados por faixa de peso, de acordo com a programação das máquinas classificadoras de ovos em uso no incubatório comercial e somente os ovos do tipo C (63 a 72g) foram utilizados, a fim de eliminar o efeito do peso do ovo sobre as condições de eclosão. Após a classificação, 1.152 ovos por tratamento foram distribuídos em 12 bandejas (repetições) com 96 ovos cada, totalizando 6.912 ovos, que foram armazenados na sala de ovos sob condições ambientais de temperatura média de 19 a $21^{\circ} \mathrm{C}$ e umidade relativa média de $76 \%$. A classificação e o armazenamento foram feitos de forma regressiva, ou seja, iniciando pelo período mais longo (9 dias) e terminando com o mais curto ( 3 dias), para que todos os ovos fossem incubados no mesmo dia e na mesma máquina, mantendo, portanto, as mesmas condições de incubação. 


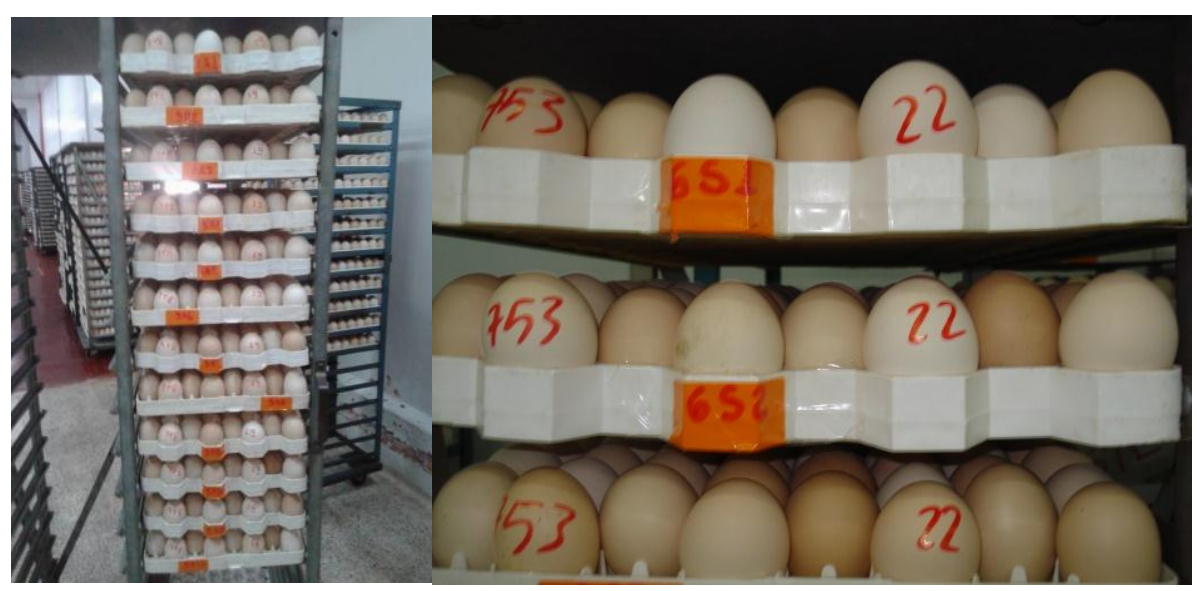

Fig. 2.1 Esquema das bandejas armazenadas na sala de ovos

Fig. 2.2 Identificação das bandejas e ovos

4.5 Qualidade dos ovos incubáveis armazenados em diferentes períodos com ou sem CLA

\subsubsection{Análises físicas da qualidade dos ovos}

Após os tempos de armazenamento pré-determinados (9, 6 e 3) na sala de ovos, uma amostra de 30 ovos de cada tratamento (cada ovo foi considerado uma repetição)foi recolhida após classificação dos ovos por faixa de peso. Assim, em cada dia de coleta, 60 ovos foram transportados até o Laboratório de Nutrição Animal da Fazenda Água Limpa-UnB para as avaliações da qualidade física, que foram efetuadas após a coleta.

Inicialmente, os ovos foram pesados individualmente utilizando-se uma balança marca GEHAKA (modelo BK3000) com precisão de 0,01g e, posteriormente, foram abertos sobre tábuas de vidro para avaliação da altura do albúmen e da gema utilizando micrômetro tripé.

Foram avaliados: altura do albúmen (AA), altura (AG) e diâmetro de gema (DG), pH de gema e albúmen (pH), peso de gema (PG) e de casca (PC), espessura de casca (EC) para o cálculo de índice de gema (IG) e para o cálculo da unidade Haugh, utilizando a fórmula: $\mathrm{UH}=100 \log \left(\mathrm{h}-1.7 \mathrm{p}^{0,37}+7,6\right)$, sendo h a altura do albúmen (mm) e p o peso do ovo (g) (BRANT \& SHRADER, 1958). As gemas foram separadas manualmente e pesadas individualmente. O peso do albúmen (PA) foi calculado através da fórmula: peso do ovo (peso da gema + peso da casca). Para o índice de gema, a fórmula utilizada foi: $\mathrm{IG}=\mathrm{h} / \mathrm{d}$, sendo $\mathrm{h}=$ altura da gema $(\mathrm{mm})$ e d = diâmetro da gema (mm), segundo Funk (1973). Os percentuais de casca $(\mathrm{C} \%)$, gema $(\mathrm{G} \%)$ e albúmen $(\mathrm{A} \%)$ foram calculados a partir dos seus respectivos pesos, divididos pelo peso do ovo e multiplicados por 100 . 
Após análises físicas, foram recolhidos separadamente "pools" de cinco gemas e de cinco claras (repetições) por tratamento, totalizando 6 repetições por tratamento, que foram congelados, liofilizados e utilizados para análises posteriores.

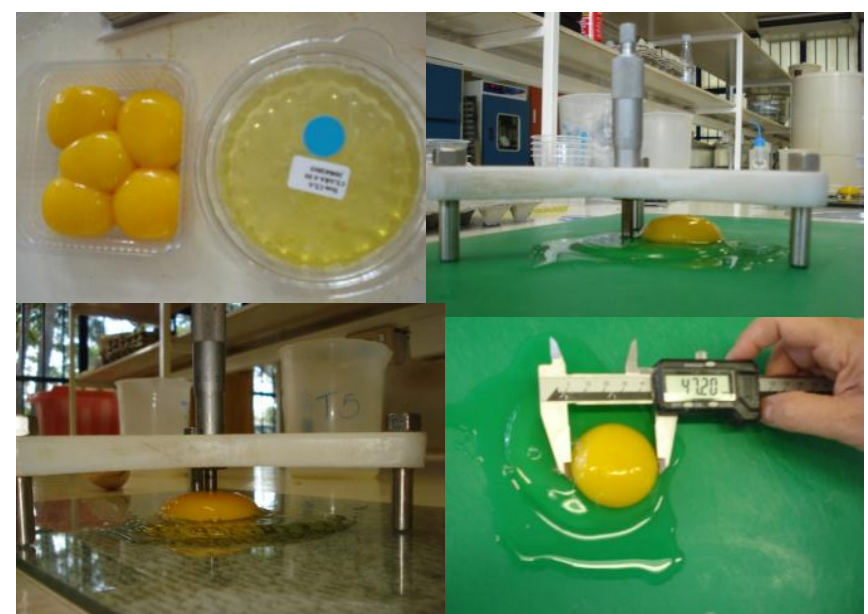

Fig 2.3 "Pools" de gemas e albúmen, avaliações de altura de albúmen, altura de gema e diâmetro de gema, da esquerda para a direita, respectivamente.

\subsubsection{Espessura e peso da casca (EC)}

Após a higienização e remoção da membrana testácea, as cascas foram dispostas em bandejas para secagem em temperatura ambiente durante uma semana. As aferições de espessura de casca foram realizadas em triplicata na porção equatorial das cascas dos ovos (Oliveira \& Oliveira, 2013) com micrômetro digital marca Vonder (modelo IP 65) e a pesagem foi feita em balança de precisão da marca OHAUS (modelo Adventurer).

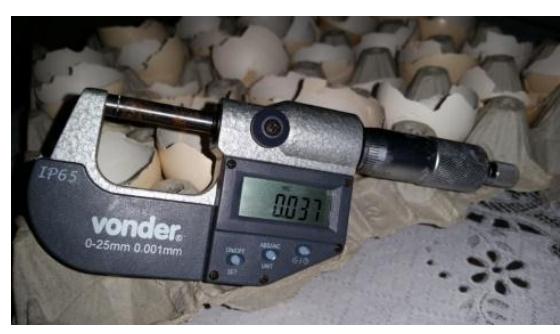

Fig 2.4 Micrômetro digital 
4.5.3 pH da gema e albúmen $(\mathrm{pH})$

A aferição do $\mathrm{pH}$ do albúmen e da gema foi realizada em triplicata em cada "pool" de amostras, totalizando de 18 leituras por tratamento, utilizando um pHmetro digital portátil da marca texto (modelo T 205) (Fig. 2.5).

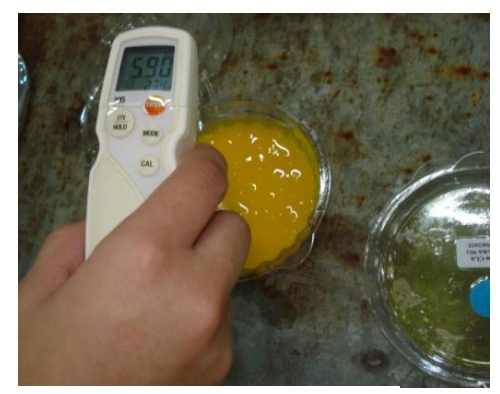

Fig 2.5 pHmetro digital

4.6 Composição centesimal

4.6.1 Determinação de umidade

A determinação de umidade foi realizada nos "pools" de gemas (UG) e albúmen frescos (UA) conservados em geladeira e mantidos em temperatura ambiente até a estabilização antes das pesagens, totalizando seis repetições por tratamento. A metodologia utilizada foi conforme AOAC (1995) em estufa à temperatura de $105^{\circ} \mathrm{C}$ até peso constante. A equação utilizada para cálculo foi: Umidade $=100 \%$ - \% Matéria Seca

4.6.2 Determinação da proteína bruta (PBG) (PBA)

A determinação de proteína bruta foi realizada em três repetições por tratamento nas amostras de gema e albúmen, através do método de Micro-Kjeldahl, conforme AOAC (1995). 
4.6.3 Determinação do extrato etéreo das gemas (EEG)

O extrato etéreo das gemas foi determinado em três repetições por tratamento nas amostras de gemas liofilizadas e moídas, segundo AOAC (1990).

4.6.4 Determinação da matéria mineral (MMG) e (MMA)

A determinação da matéria mineral foi feita em duplicata, totalizando 6repetições por tratamento. As amostras de albúmen foram submetidas à estufa durante 6 horas para pré-secagem e posteriormente à mufla (Gomes, 2011). As amostras de gemas liofilizadas e moídas foram submetidas à combustão total em mufla $\left(600^{\circ}\right)$ para combustão total da matéria orgânica, segundo a metodologia da AOAC (1990). A equação utilizada para cálculo foi: $\mathrm{RMF}=\mathrm{C} / \mathrm{A} * 100$, sendo $\mathrm{RMF}$ o resíduo mineral fixo, $\mathrm{C}$ o peso da cinza (g) e A o pesa da amostra (g).

\subsection{Análise de oxidação lipídica}

Para avaliar de uma forma abrangente a oxidação lipídica das gemas foram realizadas três tipos de analises nos ovos durante o armazenamento: índice de acidez, índice de peróxidos e TBARS.

\subsection{1 Índice de acidez (IA)}

As analises de acidez das gemas foram realizadas na porção lipídica obtida do “pool” das gemas liofilizadas após a extração com solvente à frio pelo método Bligh-Dyer adaptado por Folchem duplicata totalizando 12 análises por tratamento (a cada "pool" de gemas) em duplicatas totalizando 12 avaliações por tratamento. 


\subsection{2 Índice de peróxidos (IP)}

É um indicador de oxidação do óleo ou gordura (Gomes, 2011; Bertechini, 2012), sendo expresso em miliequivalentes de peróxidos/kg de gordura As análises foram realizadas de acordo com metodologia de peróxidos para farinhas (Instituto Adolfo Lutz, 2008 e SINDIRAÇÕES, 2013) em gemas liofilizadas com seis repetições por tratamento.

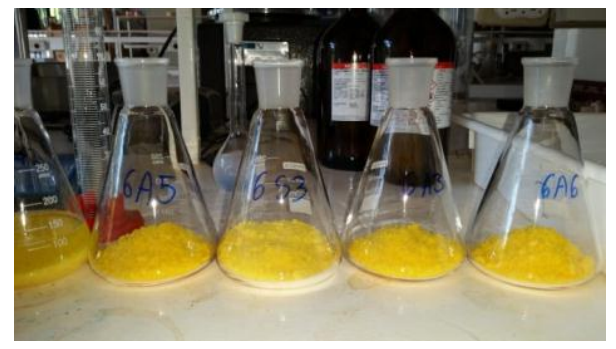

Figura 2.6 Amostras de gemas liofilizadas para análise de peróxidos

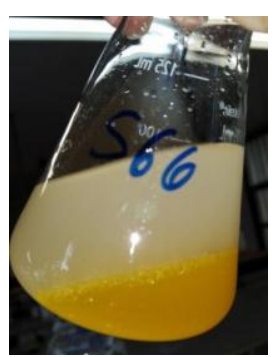

Figura 2.7 Análise de peróxidos

\subsubsection{Substâncias reativas ao ácido tiobarbitúrico (TBARS)}

A avaliação da oxidação lipídica foi feita através quantificação dos compostos secundários pelo método de TBARS (substâncias reativas ao ácido tiobarbitúrico) descrito por Vyncke (1970 e 1975) e modificado por Sorensen \& Jorsensen (1996). As análises foram realizadas nos "pools" de gemas dos ovos (TBARSG) armazenados durante diferentes tempos na sala de ovos (3, 6 e 9 dias) em seis repetições/tratamento.

A separação das amostras de ovos ocorreu imediatamente após a realização das análises físicas. As gemas foram coletadas em tubos tipo falcon e adicionados $15 \mathrm{ml}$ da solução de ácido tricloroacético (TCA 7,5\%), contendo $0,1 \%$ de ácido etilenodiaminotetracético (EDTA) e $0,1 \%$ de propilgalato (PG) preparada em água mili-Q. e imediatamente levadas à geladeira até a realização das análises, que ocorreram 24 horas após a coleta devido à grande quantidade de análises realizadas nos dias de coleta de ovos.

Após filtração, foram pipetados 5 mlem tubos de ensaio e adicionados de $5 \mathrm{~mL}$ da solução de TBA (2-thiobarbituric acid), levados à banho-maria $\left(100^{\circ} \mathrm{C}\right.$ durante 40 min).Após resfriamento em banho frio foi realizada a leitura da absorbância em 532 e $600 \mathrm{~nm}$ usando espectrofotômetro marca GEHAKA, modelo UV 340G. E Os resultados foram expressos em $\mu \mathrm{mol}$ de malonaldeídos (MDA)/kg de amostra usando uma curva padrão feita com 1,1,3,3-tetraetoxipropano ( $\left.\mathrm{y}=0,0804 \mathrm{x}+0,0077 ; \mathrm{R}^{2}=0,9999\right)$. 
4.8 Delineamento experimental e análise estatística

Os ovos foram distribuídos em blocos ao acaso, sendo considerado o bloco a posição das bandejas de ovos nos carrinhos dentro da sala de ovos, em um esquema fatorial $2 \times 3$ (com ou sem inclusão de CLA nas dietas das matrizes x 3 períodos de armazenamento 3,6 e 9 dias).

Para as avaliações físicas dos ovos, foram utilizados 30 ovos de cada tratamento. As análises de umidade e matéria mineral foram realizadas em 6 repetições por tratamento, todavia, a proteína bruta e extrato etéreo foram realizadas em 3 repetições por tratamento.

Os dados obtidos foram comparados adotando um modelo misto, com efeito fixo para os tratamentos e aleatórios para os períodos de armazenamento, utilizando-se o procedimento PROC MIXED do software Statistical Analisys Sistem (SAS 9.3®). As médias foram comparadas pelo teste de Tukey com significância de $5 \%$. 


\section{RESULTADOS E DISCUSSÃO}

5.1 Qualidade dos ovos incubáveis armazenados em diferentes períodos com ou sem inclusão de CLA

\subsubsection{Análises físicas da qualidade dos ovos}

$\mathrm{Na}$ avaliação geral da qualidade da gema, o peso das gemas (PG) não foi afetado pela adição de CLA nem pelo armazenamento na sala de ovos, assim como não apresentou interação entre os fatores principais (Tabela 2.2), bem como encontrado por Scott \& Silversides (2000).

Não houve efeito da inclusão de CLA para altura de gema (AG), bem como interação entre os fatores principais. No entanto, AG foi afetada pelos tempos de armazenamento de maneira decrescente, assim como descrito anteriormente por Macari et al. (2013) e Oliveira \& Oliveira (2013).

O índice de gema (IG) foi preservado com a adição do CLA, porém os tempos de armazenamento interferiram negativamente nesse parâmetro que diminui à medida que aumentou o tempo de armazenamento, conforme observado por Souza et al. (2013). Saldanha (2008) encontrou valores de IG de 0,42; 0,40 e 0,38 para ovos armazenados por 3, 7 e 14 dias. Segundo Oliveira \& Oliveira (2013) o parâmetro de qualidade de índice de gema está entre 0,39 e 0,45 . 
A adição de CLA não afetou a porcentagem de gema (G\%), somente o tempo de armazenamento, sendo que os valores médios de G\% aumentaram à medida que aumentou o tempo de armazenamento. Esse fato pode ser explicado pela diminuição do peso do albúmen com o aumento dos tempos de armazenamento, uma vez que o PG não foi afetado pelos tratamentos. Segundo Macari et al. (2013), a diferença de pressão osmótica é responsável pela movimentação de água do albúmen para a gema durante o armazenamento, assim, a porcentagem de gema aumenta e a de albúmen reduz, ocorrendo o alargamento da gema e a diminuição da sua viscosidade. Shang et al. (2004) verificaram que o percentual de gema diminuiu conforme aumentou o CLA dietético. Contudo, o nível utilizado neste estudo (0,023\% de CLA), pode ter contribuído para os resultados encontrados. Santos et al. (2009) verificaram que o período de armazenamento alterou a qualidade dos ovos em relação aos parâmetros perda de peso, percentagens de gema e clara, gravidade específica e unidades Haugh.

A proporção de gema:albúmen (PGA) não foi afetada pela adição de CLA, mas aumentou com a progressão do armazenamento, o que é resultado da redução do peso do albúmen (Tabela 2.4) ao armazenamento, uma vez que o peso da gema não variou com os tratamentos.

$\mathrm{O}$ pH das gemas não diferiu com a inclusão do CLA, mas o armazenamento provocou aumento nos valores médios encontrados, conforme verificado por Ganeco et al. (2012), que avaliaram ovos armazenados durante 14, 28, 42 e 56 dias em condições refrigeradas. $\mathrm{O}$ pH das gemas não sofreu alteração, nem mesmo nos maiores períodos de armazenamento, com valores de 6,33;6,49;6,42 e 6,39 respectivamente. Segundo Macari et al. (2013), com o aumento do tempo de armazenamento há o aumento do $\mathrm{pH}$ e perda de $\mathrm{CO}_{2}$ que provocam a diminuição da altura do albúmen, necessário para atender às altas demandas de captação de $\mathrm{O}_{2}$ pelo embrião, com transmissão de água para as gemas devido ao gradiente de pressão osmótica. Essa diminuição da altura do albúmen, e consequentemente da UH, é ocasionada pela sua liquefação (Karoui et al., 2006) causada pelas reações com o ácido carbônico $\left(\mathrm{H}_{2} \mathrm{CO}_{3}\right)$, que tem ação tamponante sobre o albúmen e dissocia-se em água e gás carbônico quando em condição de armazenamento dos ovos (Romanoff \& Romanoff, 1963), essa modificações podem ser associadas às enzimas presentes no albúmen que hidrolisam as cadeias de aminoácidos durante o armazenamento e liberam água das moléculas de proteínas (Oliveira \& Oliveira, 2013). Todas essas alterações são sinais da perda de qualidade dos ovos (Karoui et al., 2006). 
Tabela 2.2 Valores médios do peso (PG, g), diâmetro (DG, mm), altura (AG, mm), índice (IG) e porcentagem (G\%) de gema, proporção gema:albúmen (PGA) e pH de gemas provenientes de ovos armazenados durante 3, 6 e 9 dias com e sem inclusão de CLA

\begin{tabular}{cccccccc}
\hline Tratamentos & PG & DG & AG & ${ }^{1}$ IG & ${ }^{2} \mathrm{G} \%$ & ${ }^{3}$ PGA & pH \\
\hline C/CLA & 22,04 & 45,66 & 18,81 & $0,41^{\mathrm{A}}$ & 32,34 & 54,75 & 5,74 \\
S/ CLA & 21,65 & 46,11 & 18,46 & $0,40^{\mathrm{B}}$ & 31,81 & 53,45 & 5,75 \\
Arm3 & 21,71 & 44,80 & $19,90^{\mathrm{A}}$ & $0,44^{\mathrm{A}}$ & $31,53^{\mathrm{B}}$ & $52,62^{\mathrm{B}}$ & $5,72^{\mathrm{B}}$ \\
Arm6 & 21,96 & 46,08 & $18,86^{\mathrm{B}}$ & $0,41^{\mathrm{B}}$ & $31,99^{\mathrm{A}}$ & $53,64^{\mathrm{B}}$ & $5,75^{\mathrm{A}}$ \\
Arm9 & 21,87 & 46,78 & $17,16^{\mathrm{C}}$ & $0,37^{\mathrm{C}}$ & $32,70^{\mathrm{A}}$ & $56,03^{\mathrm{A}}$ & $5,78^{\mathrm{A}}$ \\
\cline { 2 - 8 } & \multicolumn{7}{c}{ Valor de P } \\
CLA & 0,0949 & 0,0134 & 0,0829 & 0,0151 & 0,0839 & 0,1075 & 0,4336 \\
Arm & 0,6662 & $<0,0001$ & $<0,0001$ & $<0,0001$ & 0,0080 & 0,0021 & 0,0001 \\
CLA x Arm & 0,0968 & 0,0382 & 0,5045 & 0,9789 & 0,3869 & 0,2862 & 0,9022 \\
CV (\%) & 7,18 & 4,15 & 9,44 & 11,07 & 6,57 & 10,23 & 0,91 \\
\hline
\end{tabular}

Médias seguidas de letras distintas na mesma coluna diferem entre si pelo teste de Tukey $(\mathrm{p}<0,05)$.

Número de repetições $(\mathrm{n})=30$

'Índice de gema $(\mathrm{IG})=$ altura gema/diâmetro da gema

${ }^{2}$ Porcentagem de gema $(\mathrm{G} \%)=($ peso da gema/peso do ovo $) \times 100$

${ }^{3}$ Proporção gema:albúmen $(\mathrm{PGA} \%)=($ peso da gema/peso do albúmen $) \times 100$

A adição de CLA e o tempo de armazenamento afetaram o diâmetro da gema DG (Tabela 2.2) que aumentou com o tempo de armazenamento, como esperado. Além disso, verifica-se efeito para a adição de CLA e para os tempos de armazenamento (Tabela 2.3). Entre os dois tratamentos (com e sem CLA), os piores resultados de DG foram obtidos para os ovos armazenados durante nove dias, pois quanto mais liquefeita a gema, maior o diâmetro (Macari et al., 2013; Oliveira \& Oliveira, 2013). No entanto, o tratamento com CLA preservou o DG, apresentando valores menores até o sexto dia, enquanto no tratamento sem CLA o DG apresentou valores maiores desde o terceiro dia de armazenamento.

Tabela 2.3 Desdobramento da interação entre tempos de armazenamento e inclusão ou não de CLA no diâmetro da gema (DG)

\begin{tabular}{|c|c|c|c|c|c|}
\hline \multirow[t]{2}{*}{ Tratamentos } & \multicolumn{3}{|c|}{ Tempo de Armazenamento } & \multirow[t]{2}{*}{$\mathrm{P}$} & \multirow[t]{2}{*}{ CV\% } \\
\hline & 3 & 6 & 9 & & \\
\hline Com CLA & $44,48^{\mathrm{c}}$ & $45,63^{\mathrm{bB}}$ & $46,87^{\mathrm{a}}$ & $<0,0001$ & 0,13 \\
\hline Sem CLA & $45,12^{\mathrm{b}}$ & $46,52^{\mathrm{aA}}$ & $46,68^{\mathrm{a}}$ & $<0,0001$ & 0,13 \\
\hline
\end{tabular}

Médias seguidas de letras diferentes minúsculas na linha e maiúsculas na coluna diferem entre si pelo teste de Tukey $(\mathrm{P}<0,05)$

Na tabela 2.4 encontram-se os parâmetros de qualidade do albúmen, na qual se pode observar que a inclusão do CLA não afetou o peso do albúmen (PA), já o armazenamento interferiu nesse parâmetro reduzindo o PA aos 9 dias. Resultados semelhantes foram encontrados por Scott \& Silversides (2000) que avaliaram que com o aumento do tempo de armazenamento, o peso do albúmen diminuiu, causando diminuição no peso do ovo. 
Isso porque o armazenamento causa o aumento no $\mathrm{pH}$ é responsável por diminuir a acidez do albúmen (Romanoff \& Romanoff, 1963) e é causado pela perda de $\mathrm{CO}_{2}$ através dos poros da casca, ocasionando a liquefação do albúmen (Karoui et al., 2006) e diminuição da sua altura, devido às reações químicas envolvendo ácido carbônico $\left(\mathrm{H}_{2} \mathrm{CO}_{3}\right)$ que é responsável pelo sistema tampão do albúmen e após dissociação forma água e gás carbônico (Romanoff \& Romanoff, 1963).

O CLA nas rações das matrizes interferiu na altura de albúmen (AA), bem como os diferentes períodos de armazenamento, porém não houve interação entre os fatores. A inclusão do CLA foi positiva para a AA, uma vez que atuou na manutenção da qualidade do albúmen em relação ao grupo sem CLA. Por sua vez, o armazenamento reduziu a AA à medida que avançou, resultando em declínio da qualidade do albúmen, como era esperado. Segundo Stevens (1996) a redução da altura do albúmen pode ser causada pela proteólise da ovomucina, pela clivagem das pontes de dissulfitos ou também pelas interações entre $\alpha$ e $\beta$ ovomucinas.

O CLA não modificou a porcentagem de albúmen (A\%), similar ao encontrado por Franco (2007) e, contrário à Shang et al. (2004) que verificaram aumento no percentual de albúmen conforme aumentou o CLA dietético, já os tempos de armazenamento diminuíram A\% à medida que aumentaram. Esse resultado é reflexo dos encontrados para PA e AA, que também diminuíram no maior tempo de armazenamento.

A inclusão de CLA garantiu melhores resultados de UH, mas os tempos de armazenamento pioraram os esses índices, que foram similares entre os dias três e seis, com declínio expressivo aos nove dias de armazenamento. Assim como observado por Macari et al. (2013), quanto maiores os tempos de armazenamento, pior será a qualidade do albúmen, sendo representada pela unidade Haugh (UH), que é o principal aferidor da qualidade de ovos de consumo, representado pela altura do albúmen corrigida para o peso do ovo. Santos et al. (2009) notaram que maiores períodos de armazenamento, independentemente das condições de conservação, diminuem a qualidade da UH. Os resultados de UH encontrados neste experimento ficaram muito aquém do esperado para ovos férteis, cujo ideal seria próximo à 80 (Macari et al., 2013), para garantia de bons resultados de eclodibilidade ideal, em torno de 88\% (Rosa \& Avila, 2000). Isso pode ser justificado pela idade das matrizes experimentais, que tinham entre 58 e 60 semanas, pois, com o aumento da idade das matrizes, menor é a altura de albúmen e pior é a qualidade do ovo (Oliveira \& Oliveira, 2013; Willemsen et al., 2008; Reis et al., 1997). 
Tabela 2.4 Valores médios de peso (PA, g), altura (AA, mm), porcentagem (A\%), Unidade Haugh (UH) e pH de albumen provenientes de ovos armazenados durante 3, 6 e 9 dias com e sem inclusão de CLA

\begin{tabular}{cccccc}
\hline Tratamentos & PA & AA & A\% & UH & pH \\
\hline C/CLA & 40,42 & $5,23^{\mathrm{A}}$ & 59,28 & $65,68^{\mathrm{A}}$ & 9,03 \\
S/ CLA & 40,78 & $4,86^{\mathrm{B}}$ & 59,73 & $61,70^{\mathrm{B}}$ & 9,10 \\
Arm3 & $41,50^{\mathrm{A}}$ & $5,61^{\mathrm{A}}$ & $60,15^{\mathrm{A}}$ & $69,25^{\mathrm{A}}$ & 8,87 \\
Arm6 & $41,12^{\mathrm{A}}$ & $5,49^{\mathrm{A}}$ & $59,85^{\mathrm{A}}$ & $68,53^{\mathrm{A}}$ & 9,12 \\
Arm9 & $39,18^{\mathrm{B}}$ & $4,01^{\mathrm{B}}$ & $58,51^{\mathrm{B}}$ & $53,30^{\mathrm{B}}$ & 9,20 \\
\cline { 2 - 6 } & \multicolumn{5}{c}{ Valor de P } \\
CLA & 0,4267 & 0,0185 & 0,1675 & 0,0227 & 0,0051 \\
Arm & $<0,0001$ & $<0,0001$ & 0,0001 & $<0,0001$ & $<0,0001$ \\
CLA x Arm & 0,4210 & 0,4349 & 0,2351 & 0,4569 & 0,0087 \\
CV (\%) & 7,73 & 25,37 & 3,85 & 21,66 & 2,05 \\
\hline
\end{tabular}

Médias seguidas de letras distintas na mesma coluna diferem entre si pelo teste de Tukey $(\mathrm{p}<0,05)$.

Número de repetições $(\mathrm{n})=30$

Desdobrando-se a interação entre inclusão de CLA e tempos de armazenamento para os valores de $\mathrm{pH}$ do albúmen (Tabela 2.5), nota-se que o tratamento com inclusão de CLA aumentou seus valores de pH de maneira crescente até o maior período de armazenamento, sendo o melhor resultado verificado para os ovos armazenados por três dias, da mesma forma como verificado no tratamento sem CLA. Já quanto aos ovos armazenados por seis dias, o tratamento com CLA apresentou melhores valores de $\mathrm{pH}$, comparados aos do mesmo período sem CLA. Porém, os ovos que não tiveram a inclusão de CLA, os valores de $\mathrm{pH}$ foram maiores já no sexto dia de armazenamento, com valor maior do que o encontrado no armazenamento de nove dias no grupo com CLA. A inclusão do CLA foi positiva para manutenção do $\mathrm{pH}$ do albúmen durante o armazenamento prolongado. Segundo observado por Oliveira \& Oliveira (2013), o pH do albúmen está diretamente relacionado com a altura de albúmen e UH, sendo bom indicativo de frescor dos ovos com valor ideal em torno de 7,7 e quando armazenados de 9,0 a 9,5. Silversides \& Scott (2001) citam o pH como o melhor aferidor da qualidade dos ovos frescos, que sofre grande influência dos tempos maiores de armazenamento, pois a medida que aumenta o tempo de armazenamento, a altura do albúmen diminui e o pH aumenta. Xavier (2006) verificou que valores da altura do albúmen e UH diminuem razoavelmente com o armazenamento. Saldanha (2008) encontrou queda expressiva nos valores de UH de ovos armazenados durante 0, 3, 7, 10 e 14 dias com valores de UH de 83,30; 72,62; 66,93; 62,11 e 56,35 respectivamente. Ganeco et al. (2012) encontraram valores crescentes de $\mathrm{pH}$ do albúmen com o aumento do tempos de armazenamento, que e é causado pela perda de $\mathrm{CO}_{2}$ através dos poros da casca (Karoui et al., 2006), devido às reações químicas envolvendo ácido carbônico $\left(\mathrm{H}_{2} \mathrm{CO}_{3}\right)$ que é responsável 
pelo sistema tampão do albúmen e após dissociação forma água e gás carbônico (Romanoff \& Romanoff, 1963).

Tabela 2.5 Desdobramento da interação entre tempos de armazenamento e inclusão ou não de CLA no $\mathrm{pH}$ do albúmen

\begin{tabular}{|c|c|c|c|c|c|}
\hline \multirow[t]{2}{*}{ Tratamentos } & \multicolumn{3}{|c|}{ Tempo de Armazenamento } & \multirow[t]{2}{*}{$\mathrm{P}$} & \multirow[t]{2}{*}{ CV\% } \\
\hline & 3 & 6 & 9 & & \\
\hline Com CLA & $8,86^{\mathrm{c}}$ & $9,03^{\mathrm{bB}}$ & $9,19^{\mathrm{a}}$ & $<0,0001$ & 0,02 \\
\hline Sem CLA & $8,88^{\mathrm{b}}$ & $9,21^{\mathrm{aA}}$ & $9,20^{\mathrm{a}}$ & $<0,0001$ & 0,02 \\
\hline
\end{tabular}

Médias seguidas de letras diferentes minúsculas na linha e maiúsculas na coluna diferem entre si pelo teste de Tukey $(\mathrm{P}<0,05)$

$\mathrm{Na}$ Tabela 2.6 estão apresentados os valores para qualidade das cascas e notase que o tempo de armazenamento afetou a porcentagem de cascas (PC), aumentando os valores com a progressão do armazenamento, sendo os maiores resultados para os ovos armazenados por nove dias. Isso pode ser explicado pelo maior peso inicial dos ovos (Tabela 3.1) que foram armazenados aos nove dias e receberam CLA. Por outro lado, a adição do CLA não afetou esta característica dos ovos.

Não houve efeito do CLA na porcentagem de cascas (C\%), que apresentaram valores semelhantes aos encontrados por Barbosa et al. (2012), cerca de 8,6\% para matrizes Cobb® de 58 a 60 semanas de idade e também aos encontrados por Franco (2007), que avaliaram os efeitos da suplementação de CLA no percentual de casca das matrizes de 43 a 51 semanas. Diferentemente de Shang et. al. (2004) que encontraram maiores percentuais de casca com o aumento dos níveis de CLA na dieta. No entanto, neste estudo, o tempo de armazenamento influenciou a $\mathrm{C} \%$, sendo que esse efeito parece estar associado ao exposto anteriormente (idade da matriz e peso inicial do ovo).

Tabela 2.6 Valores médios do peso (PC, g) espessura $(\mathrm{EC}, \mathrm{mm})$ e porcentagem $(\mathrm{C} \%)$ de cascas de ovos armazenados durante 3, 6 e 9 dias com e sem inclusão de CLA

\begin{tabular}{cccc}
\hline Tratamentos & PC & EC & C\% \\
\hline C/CLA & 5,71 & 0,35 & 8,38 \\
S/ CLA & 5,76 & 0,36 & 8,46 \\
Arm3 & $5,73^{\mathrm{A}}$ & 0,35 & $8,32^{\mathrm{B}}$ \\
Arm6 & $5,60^{\mathrm{B}}$ & 0,34 & $8,16^{\mathrm{B}}$ \\
Arm9 & $5,87^{\mathrm{A}}$ & 0,36 & $8,78^{\mathrm{A}}$ \\
& \multicolumn{3}{|}{} \\
CLLA & 0,4917 & Valor de P & 0,3798 \\
Arm & 0,0039 & $<0,0001$ & $<0,0001$ \\
CLA x Arm & 0,0646 & $<0,0001$ & 0,3483 \\
CV $(\%)$ & 8,02 & $<0,0001$ & 8,03 \\
\hline
\end{tabular}

Médias seguidas de letras distintas na mesma coluna diferem entre si pelo teste de Tukey $(\mathrm{p}<0,05)$.

Número de repetições $(\mathrm{n})=30$ 
Desdobrando-se a interação para espessura de casca - EC (Tabela 2.7), observa-se que o tratamento com CLA produziu cascas mais finas, com exceção do sexto dia de armazenamento. O tratamento sem CLA apresentou EC mais grossas à medida que o armazenamento aumentou fato que pode ser explicado pelos tempos regressivos aos quais foram submetidos os ovos antes do armazenamento. Esses resultados podem ser atribuídos, mais uma vez, à idade das matrizes que tinham entre 58 e 60 semanas durante o período experimental. Barbosa et al. (2012) verificaram que a qualidade das cascas dos ovos de matrizes velhas é inferior aos de matrizes mais novas, o que pode justificar maiores perdas de peso dos ovos de matrizes mais velhas. Em seu estudo com matrizes Cobb® com 33 e 63 semanas verificaram que os ovos de matrizes com 33 semanas foram mais leves, e o número de poros por $\mathrm{cm}^{2}$ foi menor que o de ovos das aves mais velhas. Ovos de aves com 63 semanas apresentaram menor percentual de casca em relação ao peso do ovo, menor peso específico e menor resistência e espessura da casca. Oliveira \& Oliveira (2013) encontraram valores de 0,31 $\mathrm{mm}$ para espessura de casca em matrizes e citam haver tendência de serem maiores para ovos de postura após muda forçada. Já quanto às maiores espessuras encontradas para os ovos armazenados por maior tempo, estas podem ser explicadas pela idade da fêmea à postura, já que eles foram armazenados de forma regressiva, ou seja, iniciando pelo período mais longo (nove dias) e terminando com o mais curto (três dias).

Tabela 2.7 Desdobramento da interação entre tempos de armazenamento e inclusão ou não de CLA na espessura das cascas de ovos (EC) em milímetros (mm)

\begin{tabular}{|c|c|c|c|c|c|}
\hline \multirow[t]{2}{*}{ Tratamentos } & \multicolumn{3}{|c|}{ Tempo de Armazenamento } & \multirow[t]{2}{*}{$\mathrm{P}$} & \multirow[t]{2}{*}{ CV\% } \\
\hline & 3 & 6 & 9 & & \\
\hline Com CLA & $0,34^{\mathrm{B}}$ & $0,35^{\mathrm{A}}$ & $0,35^{\mathrm{B}}$ & $<0,0001$ & 0,002 \\
\hline Sem CLA & $0,36^{\mathrm{cA}}$ & $0,34^{\mathrm{bB}}$ & $0,38^{\mathrm{aA}}$ & $<0,0001$ & 0,002 \\
\hline
\end{tabular}

Médias seguidas de letras diferentes minúsculas na linha e maiúsculas na coluna diferem entre si pelo teste de Tukey $(\mathrm{P}<0,05)$

\subsubsection{Composição centesimal dos ovos}

Na Tabela 2.8 nota-se que a inclusão de CLA não influenciou a composição centesimal dos ovos, diferentemente dos tempos de armazenamento que aumentaram a umidade (UG) e reduziram a matéria mineral (MMG) e o extrato etéreo das gemas (EEG) das gemas. Sabe-se que durante o armazenamento ocorre transferência da água do albúmen para as gemas, que ficam liquefeitas (Macari et al., 2013; Oliveira \& Oliveira, 2013). Os resultados encontrados para UG se refletiram em diversos parâmetros de qualidade das gemas como 
diâmetro, altura, índice de gema, porcentagem, proporção gema:albúmen e pH, que também apresentaram valores crescentes com o avanço dos tempos de armazenamento.

Tabela 2.8 Valores médios percentuais (\%) de umidade das gemas (UG), umidade do albúmen (UA), matéria mineral das gemas (MMG), matéria mineral do albúmen (MMA), proteína bruta das gemas (PPG), proteína bruta do albúmen (PBA) e extrato etéreo das gemas (EEG) provenientes de ovos armazenados durante 3, 6 e 9 dias com e sem inclusão de CLA

\begin{tabular}{cccccccc}
\hline Tratamentos & UG & UA & MMG & MMA & PBG & PBA & EEG \\
\hline C/CLA & 50,69 & 87,50 & 1,79 & 0,64 & 15,88 & 12,93 & 30,71 \\
S/ CLA & 51,15 & 87,39 & 1,77 & 0,70 & 14,81 & 13,24 & 30,61 \\
Arm3 & $50,21^{\mathrm{B}}$ & 87,63 & $1,89^{\mathrm{A}}$ & 0,70 & 15,66 & 12,69 & $33,17^{\mathrm{A}}$ \\
Arm6 & $50,77^{\mathrm{B}}$ & 87,35 & $1,78^{\mathrm{B}}$ & 0,65 & 15,82 & 13,27 & $29,97^{\mathrm{B}}$ \\
Arm9 & $51,77^{\mathrm{A}}$ & 87,35 & $1,69^{\mathrm{C}}$ & 0,66 & 14,55 & 13,30 & $28,84^{\mathrm{C}}$ \\
\cline { 2 - 8 } & \multicolumn{7}{c}{ Valor de P } \\
CLA & 0,1320 & 0,5230 & 0,4220 & 0,0587 & 0,0799 & 0,3873 & 0,7937 \\
Arm & 0,0005 & 0,2986 & $<0,0001$ & 0,3900 & 0,1514 & 0,2987 & $<0,0001$ \\
CLA x Arm & 0,6883 & 0,3387 & 0,8641 & 0,6109 & 0,5315 & 0,1683 & 0,5527 \\
CV (\%) & 3,65 & 0,60 & 5,66 & 13,81 & 9,27 & 5,92 & 6,51 \\
\hline
\end{tabular}

Médias seguidas de letras distintas na mesma coluna diferem entre si pelo teste de Tukey $(\mathrm{p}<0,05)$.

Número de repetições umidade e matéria mineral $(n)=6$

Número de repetições proteína bruta e extrato etéreo $(n)=3$

A matéria mineral das gemas $(\mathrm{MMG})$ foi reduzida à medida que aumentou $\mathrm{o}$ armazenamento, diferindo do encontrado por Aydin et al. (2001), que observaram que ovos de galinhas alimentadas CLA e armazenadas a $15^{\circ} \mathrm{C}$ durante 10 semanas apresentaram movimento significativo de minerais $(\mathrm{Ca}, \mathrm{Mg}, \mathrm{Fe}, \mathrm{Na}$ e $\mathrm{Zn})$ entre gema e albúmen. Leone et al. (2009) verificaram movimentação mineral entre a gema e o albúmen em ovos com inclusão de $0,5 \%$ de CLA armazenados por $48 \mathrm{~h}$ em duas temperaturas distintas $\left(15^{\circ}\right.$ e $\left.21^{\circ}\right)$, no qual o $\mathrm{Mg}$ das gemas aumentou quando comparadas ao controle (suplementado $0,5 \%$ de óleo de canola) aos $21^{\circ} \mathrm{C}$ houve aumento de $27 \%$ e aos $15^{\circ} \mathrm{C}$ de $16 \%$ do $\mathrm{Mg}$ nas gemas $(\mathrm{P}<0.0001)$. Neste estudo, a MMG parece ter sido modificada pela movimentação hídrica entre albúmen-gema, o que modificou o MMG.

O CLA não influenciou o EEG nas gemas, mas os tempos de armazenamento reduziram o teor de EEG em 3,2\% do período de três a seis dias e 4,3\% no período de três a nove dias. Vale ressaltar que esses resultados podem prejudicar a sobrevivência dos embriões que retiram energia do conteúdo lipídico das gemas para o adequado desenvolvimento embrionário (Deeming, 2002). Esses resultados de EEG são devidos à liquefação das gemas, uma vez que o armazenamento modifica o $\mathrm{pH}$ e causa perda de $\mathrm{CO}_{2}$ através dos poros da casca, devido às reações químicas envolvendo ácido carbônico $\left(\mathrm{H}_{2} \mathrm{CO}_{3}\right)$ (Romanoff \& Romanoff, 1963). Consequentemente, ocorre o aumento de gradiente de pressão osmótica 
entre albúmen e gema com a entrada de água na gema, aumentando o seu alargamento e diminuindo a viscosidade (Macari et al., 2013).

5.1.3 Oxidação lipídica de ovos armazenados em diferentes períodos na sala de ovos

Observando os resultados que estão apresentados na Tabela 2.9 as análises de TBARSG são similares aos encontrados por Hayat et al. (2010). A inclusão de CLA na dieta das matrizes apresentou um efeito positivo reduzindo os valores médios de TBARS das gemas (TBARSG), o que indica a eficiência do CLA como antioxidante. No entanto, Leone et al. (2009) e Audyn \& Cook (2009) citam que o CLA dietético induz o aumento de ácidos graxos saturados, e o que pode também levar à diminuição da formação dos produtos de oxidação lipídica, como o malonaldeído - MDA (Joo et al., 2002) o que, não necessariamente, significa menor oxidação.

Tabelas 2.9 Valores médios da avaliação das substâncias reativas ao ácido tiobarbitúrico das gemas (TBARSG) e índices de acidez das gemas (IAG) provenientes de ovos armazenados durante 3, 6 e 9 dias com e sem inclusão de CLA

\begin{tabular}{ccc}
\hline Tratamentos & TBARSG & IAG \\
\hline C/CLA & 0,41 & 1,90 \\
S/ CLA & 0,51 & 1,90 \\
Arm3 & 0,42 & 1,84 \\
Arm6 & 0,76 & 1,98 \\
Arm9 & 0,19 & 1,83 \\
& \multicolumn{2}{|}{} \\
CLA & 0,0082 & 0,9950 \\
Arm & $<0,0001$ & 0,1276 \\
CLA x Arm & 0,0129 & 0,0053 \\
CV (\%) & 58,71 & 15,96 \\
\hline
\end{tabular}

Médias seguidas de letras distintas na mesma coluna diferem entre si pelo teste de Tukey $(\mathrm{p}<0,05)$.

Número de repetições $(n)=6$

Por outro lado, os tempos de armazenamento provocaram aumento dos valores de TBARSG até o sexto dia, reduzindo a valores menores do que os iniciais aos nove dias. Também foi verificada interação entre os fatores principais para o TBARSG (Tabela 2.9). A redução dos compostos de MDA com o avanço dos períodos de armazenamento pode sugerir degradação dos compostos, uma vez os MDA são produtos secundários da oxidação e podem reagir com vários elementos (aminas, aminoácidos, açúcares aminados, proteínas e 
nucleosídeos) ou podem formar dímeros ou trímeros de MDA, reduzindo sua disponibilidade de reação com o TBA (Esterbauer et al., 1991).

Na Tabela 2.10 observa-se o desdobramento da interação entre inclusão de CLA e tempos de armazenamento para o TBARSG. A inclusão do CLA na dieta das matrizes reduziu a oxidação das gemas dos ovos armazenados por até três dias, porém o mesmo não se repetiu para os outros períodos de armazenamento. Com relação aos diferentes tempos de armazenamento, ambos os tratamentos (com e sem inclusão de CLA) apresentaram resultados similares, sendo que a produção de compostos secundários de oxidação lipídica aumentou ao sexto dia e reduziu novamente aos nove dias.

Tabela 2.10 Desdobramento da interação entre tempos de armazenamento e inclusão ou não de CLA no índice de TBARS nas gemas (TBARSG), em $\mu$ mol MDA $/ \mathrm{kg}$ de gemas

\begin{tabular}{|c|c|c|c|c|c|}
\hline \multirow[t]{2}{*}{ Tratamentos } & \multicolumn{3}{|c|}{ Tempo de Armazenamento } & \multirow[t]{2}{*}{$\mathrm{P}$} & \multirow[t]{2}{*}{$\mathrm{CV} \%$} \\
\hline & 3 & 6 & 9 & & \\
\hline Com CLA & $0,29^{\mathrm{bB}}$ & $0,76^{\mathrm{a}}$ & $0,17^{b}$ & $<0,0001$ & 0,02 \\
\hline Sem CLA & $0,55^{\mathrm{bA}}$ & $0,76^{\mathrm{a}}$ & $0,21^{\mathrm{c}}$ & $<0,0001$ & 0,02 \\
\hline
\end{tabular}

Médias seguidas de letras diferentes minúsculas na linha e maiúsculas na coluna diferem entre si pelo teste de Tukey $(\mathrm{P}<0,05)$

Desdobrando-se a interação entre inclusão de CLA e tempos de armazenamento para o índice de acidez das gemas dos ovos (Tabela 2.11), nota-se que a inclusão do CLA reduziu a concentração de ácidos graxos livres nos ovos armazenados por seis dias e não diferiu para os demais tempos de armazenamento. No tratamento com CLA não houve diferença entre os períodos de armazenamento, diferentemente ao tratamento sem CLA, que apresentou resultados similares aos de TBARSG, aumentando ao sexto dia de armazenamento.

Tabela 2.11 Desdobramento da interação entre tempos de armazenamento e inclusão ou não de CLA nos índices de acidez IA (mg de NaOH/g de gordura) das gemas de ovos

\begin{tabular}{|c|c|c|c|c|c|}
\hline \multirow[t]{2}{*}{ Tratamentos } & \multicolumn{3}{|c|}{ Tempo de Armazenamento } & \multirow[t]{2}{*}{$\mathrm{P}$} & \multirow[t]{2}{*}{$\mathrm{CV} \%$} \\
\hline & 3 & 6 & 9 & & \\
\hline Com CLA & 1,90 & $1,83^{\mathrm{B}}$ & 1,93 & $<0,0001$ & 0,05 \\
\hline Sem CLA & $1,79^{\mathrm{b}}$ & $2,14^{\mathrm{aA}}$ & $1,73^{\mathrm{b}}$ & $<0,0001$ & 0,05 \\
\hline
\end{tabular}

Médias seguidas de letras diferentes minúsculas na linha e maiúsculas na coluna diferem entre si pelo teste de Tukey $(\mathrm{P}<0,05)$

A análise de peróxidos foi realizada em todos os pools de gemas hidrolisadas, mas todos os resultados foram negativos (iguais à zero), sendo assim, não houve análise estatística para esse parâmetro. Segundo Gomes (2011), a quantidade de peróxidos é muito variável durante o processo de oxidação lipídica, porém, indica até que ponto a oxidação 
progrediu. Uma vez que estes são produtos primários da oxidação muito instáveis e que variam de maneira gaussiana, baixos níveis podem significar estabilidade oxidativa, como também, degradação acelerada (Fellenberg \& Speisky, 2006). 


\section{CONCLUSÃO}

A inclusão do CLA ao nível de $0,023 \%$ na dieta das matrizes pesadas minimizou efeitos negativos e foi importante para a manutenção da qualidade física e centesimal de ovos incubáveis armazenados por até nove dias e minimizou os efeitos negativos causados pelo armazenamento prolongado. Sendo, portanto, alternativa para produção de ovos incubáveis que necessitem de armazenamento por até nove dias. 


\section{REFERÊNCIAS BIBLIOGRÁFICAS}

ANDRIGUETTO, J.M.; FILHO, A.B.; FLEMMING, J.S.; GEMAEL, A.; MINARDI, I.; PERLY, L.; SOUZA, G.A. Nutrição animal I. As bases e os fundamentos da nutrição animal. Os alimentos. São Paulo: Nobel, 2002. 395p.

AYDIN R., COOK M.E.; PARIZA M.W. Olive oil prevents the adverse effects of dietary conjugated linoleic acid on chick hatchability and egg quality. Journal of Nutrition, v. 131, p. 800-806, 2001.

AYDIN R.; COOK M. E. The effect of dietary conjugated linoleic acid on egg yolk fatty acids and hatchability in Japanese quail. Poultry Science, v. 83, p. 2016-2022, 2004.

AYDIN R.; COOK M.E. Maternal dietary conjugated linoleic acid is not directly toxic for the developing chick embryo, but causes embryo mortality by altering fatty acicomposition of the egg yolk in the chicken. Journal of the Science of Food and Agriculture, v. 89, p. 26872691, 2009.

BANNI S. Conjugated linoleic acid metabolism. Current Opinion in Lipidology, v. 13, p. 261-6, 2002.

BARBOSA, N. A. A.; SAKOMURA, N. K.; MENDONÇA, M. O.; FREITAS, E. R.; FERNANDES, J. B. K. Qualidade de ovos comerciais provenientes de poedeiras comerciais armazenados sob diferentes tempos e condições de ambientes. ARS Veterinaria, v.24, n.2, p.127-133, 2008.

BARBOSA V.M., BAIÃO N.C., CARDEAL P.C., CARDOSO D.M., CUNHA C.E., LARA L.J.C., MARTINS N.R.S., MENDES P.M.M., MIRANDA D.J.A., NELSON D.L., POMPEU M.A., ROCHA J.S.R. Evaluation of egg shell quality from broiler breeder hens with different ages. Arquivo Brasileiro de Medicina Veterinária e Zootecnia, v.64, n.4, p.1036-1044, 2012. 
BASU, S., A.; SMEDMAN; VESSBY B. Conjugated linoleic acid induces lipid peroxidation in humans. FEBS Letters, v. 468, p. 33-36, 2000.

BERTECHINI, A. G. Nutrição de monogástricos. Lavras: Editora UFLA, 2012. 373p.

BLOOM, S. E., LEE M. Y., MUSCARELLA D. E., RACHLINSKI M. Cell death in the avian blastoderm: Resistance to stress induced apoptosis and expression of anti-apoptotic genes. Cell Death Differ, v. 5, p. 529-538, 1998.

BRAND, H; BERGHMANS, D.; KEMP, B.; MEIJERHOF, R.; REIJRINK, I. A. M. Influence of egg storage time and pre incubation warming profile on embryonic development, hatchability, and chick quality Poultry Science, v. 89, n. 6, p. 1225-1238, 2010.

BRANT, A.W.; SHRADER, H.L. Equipment and methods for measuring egg quality. Washington: Department of Agriculture 17p. Agricultural Marketing Service, v. 246, 1958.

BRAKE, J., BENTON C. E., MEIJERHOF R.; PANAVALVA G.; PETITTE J. R. IN; WALSCH T. J. Egg handling and storage. Poultry Science, v. 76, p. 144-151, 1997.

BRASIL. Ministério da Ciência, Tecnologia e Inovação. Diretrizes de prática de eutanásia do CONCEA - Conselho Nacional de Controle de Experimentação Animal, 2013.

BUTOLO, J.E. Qualidade de ingredientes na alimentação animal. Colégio Brasileiro de Nutrição Animal. Campinas, 2002.p.313-319; 369-380

CARVALHO, F. B. et al. Qualidade interna e da casca para ovos de poedeiras comerciais de diferentes linhagens e idades. Ciência Animal Brasileira, v. 8, n. 1, p. 25-29, 2007.

CHERIAN, G.; SIM S. J. Net transfer and incorporation of yolk n-3 fatty acids into developing chick embryos. Poultry Science, v. 72, p. 98-105, 1993.

CHIN S.F., HA Y.L.; LIU W., PARIZA M.W. STORKSON J.M. Dietary sources of conjugated dienoic isomers of linoleic acid, a newly recognized class of anticarcinogens. Journal of Food Composition and Analysis, v. 5, p. 185-197, 1992.

COBB. Guia de Manejo de Incubação, L-1032-03, 2013.

COHEN C., PERRAUlT G., STEINBERG R.; SOUBRiÉ P. VOLTZ C. A central cannabinoid $(\mathrm{CB}(1))$ receptor antagonist, blocks the motivational and dopamine-releasing effects of nicotine in rats. Behavioural Pharmacology, v. 13, p. 451-463, 2002.

CORL B.A., BAUMGARD L.H., DWYER D.A. The role of delta-9-desaturase in the production of cis-9, trans-11. The Journal of Nutritional Biochemistry, v. 12, n. 11, p. 62230, 2001.

DEEMING D.C. Avian Incubation: behaviour, enviroment, and evolution. Lincoln: Oxford University Press, 2002 
DING, S., LILBURN M. S. Characterization of changes in yolk sac and liver lipids during embryonic and early posthatch development of turkey poults. Poultry Science, v. 75, p. 478483, 1996.

DU, M., DU. A., KC N., Sell. J. L. Volatile profiles and lipid oxidation of irradiated cooked chicken meat from laying hens fed diets containing conjugated linoleic acid. Poultry Science, v. 80, p. 235-241, 2001.

EFSA. Journal. 2016. Safety and efficacy of methylester of conjugated linoleic acid (t10,c12 isomer) for pigs for fattening, sows and cows. EFSA Journal, [1831-4732] v. 14, n. 1, 2016.

ESTERBAUER, H.; SCHAUR, R. J.; ZOLLNER, H. Chemistry and biochemistry of 4hydroxynonenal, malonaldehyde and related aldehydes. Free Radical Biology and Medicine, v. 11, n.1, p. 81-128, 1991.

EVANS M. E., BROWN J. M., MCINTOSH M. K. Isomer specific effects of conjugated linoleic acid (CLA) on adiposity and lipid metabolism. The Journal of Nutritional Biochemistry, v. 13, p. 508-516, 2002.

FASENKO, G. M., HARDIN R. T., ROBINSON F. E., WILSON J. L. Variability in preincubation embryonic developmentin domestic fowl. 2. Effects of duration of egg storage period. Poultry Science, v. 71, p. 2129-2132, 1992

FASENKO, G. M., KREMENIUK K. M., ROBINSON F. E., WHELAN A. I., WALKER A. Prestorage incubation of long-term stored broiler breeder eggs. 1. Effects on hatchability. Poultry Science, v. 80, p.1406-1411, 2001.

FASENKO, G. M. Egg Storage and the Embryo. Poultry Science, v. 86, n. 5, p. 1020-1024 doi:10.1093/ps/86.5.1020, 2007.

FELLENBERG, M.A.; SPEISKY, H. Antioxidants: their effects on broiler oxidative stress and its meat oxidative stability. World's Poultry Science Journal, v. 62, p. 53-70, 2006.

FLINTOFF-DYE NL, OMAYE ST. Antioxidant effects of conjugated linoleic acid isomers in isolated human low-density lipoproteins. Nutrition Research, v. 25, n. 1, p. 1-12, 2005.

FOGERTY A.C., FORD G.L., SVORONOS D. Octadeca-9, 11-dienoic acid in foodstuffs and in the lipids of human blood and breast milk. Nutrition Reports, v. 38, p. 937-944, 1988.

FRANCO, E. Z, Efeito do ácido linoléico conjugado na dieta de matrizes de corte e sua [tese] (Mestrado) Santa Maria (RS): Universidade Federal de Santa Maria, 2007

GALOBART, J; BARROETA, A. C; BAUCELLS, M. D.; CORTINAS, L.; GUARDIOLA, F. $\alpha$-Tocopherol transfer efficiency and lipid oxidation in fresh and spray-dried eggs enriched with n-3 polyunsaturated fatty acids. Poultry Science, v. 80, p. 1496-1505, 2001. 
GANECO, A. G.; SILVA, A. M. S.; BORBA, H.; BOIAGO, M. M.; LIMA, T. M. A.; SOUZA, P. A. Estudos comparativos de ovos armazenados em refrigeradores domésticos. Ars Veterinária, Jaboticabal,SP, v.28, n.2, p.100-104, 2012.

GOMES, J.C.; OLIVEIRA, G.F. Análises físico-químicas de alimentos. Viçosa, MG: Ed. UFV, 2011. 303p.

HA YL, STORKSON J, PARIZA MW. Inhibition of benzo(a)pyrene-induced mouse forestomach neoplasia by conjugaddienoic derivatives of ted linoleic acid. Cancer Research, v. 50, p. 1097-101, 1990.

HAYAT, Z.; CHERIAN, G.; PASHA, T. N.; KHATTAK, F. M.; JABBAR, M. A. Oxidative stability and lipid components of eggs from flax-fed hens: Effect of dietary antioxidants and storage. Poultry Science, v. 89, p. 1285-1292, 2010.

HERMANN, M ; MAHON, M G ; LINDSTEDT, K A ; NIMPF, J ; SCHNEIDER, W J. Lipoprotein Receptors in Extraembryonic Tissues of the Chicken. The Journal of biological chemistry, v. 275, n. 22, p.16837-44, 2000.

HUNTON P. Research on eggshell structure and quality: an historical overview. Brazilian Journal of Poultry Science, v. 7, p. 67-71, 2005.

INSTITUTO Adolfo Lutz.Métodos físico-químicos para análise de alimentos. São Paulo, Instituto Adolfo Lutz, 2008 p. 593-629.

JONES, S., CLANDININ M. T., FIELD C. J., MA D. W. E., ROBINSON F. E. Isomers of conjugated linoleic acid (CLA) are incorporated into egg yolk lipids by CLA-fed laying hens. Journal of Nutrition, v. 130, p. 202-205, 2000.

JONES, D. R.; THARRINGTON, J. B.; CURTIS, P. A.; ANDERSON, K. E. ; KEENER, K. M. ; JONES, F. T. Effects of cryogenic cooling of shell eggs on egg quality. Poultry Science. v. 81, n. 5, p. 727-733, 2002.

JOO, S. T., LEE J. I., HÁ Y. L., PARK. G. B. Effects of dietary conjugated linoleic acid on fatty acid composition, lipid oxidation, color, and water-holding capacity of pork loin. Journal of Animal Science, v. 80, p. 108-112, 2002.

KAROUI, R.; KEMPS, B.; BAMELIS, F.; DE KETELAERE, B.; DECUYPERE, E.; DE BAERDEMAEKER, J. Methods to evaluate egg freshness in research and industry: a review. European Food Research and Technology, v. 222, p. 727-732, 2006.

KAWAHARA S., TAKENOYAMA S., TAKUMA K., MUGURUMA M., YA-MAUCHL K. Effects of dietary supplementation with conjugated linoleic acid on fatty acid composition and lipid oxidation in chicken breast meat. Journal of Animal Science, v. 80, n. 4, p. 468-474, 2009.

KHANAL R.C., DHIMAN T.R. Biosynthesis of conjugated linoleic acid (CLA): a review. Pakistan. Journal of Nutrition, v. 3, p. 72-81, 2004. 
KILIAN, M., I. MAUTSCH, J. I. GREGOR, P. STAHLKNECHT, C. A. JACOBI, I. SCHIMKE, H. GUSKI AND F. A. WENGER. Influence of conjugated linoleic acid vs. conventional linoleic acid on liver metastasis and hepatic lipid peroxidation in BOP-induced pancreatic cancer in Syrian hamster. Prosta. Leuko. Essential Fatty Acids, v. 67, p. 223-228, 2002.

KIM JH, HUBBARD NE, ZIBOH V, ERICKSON KL. Attenuation of breast tumor cell growth by conjugated linoleic acid via inhibition of 5-lipoxygenase activating protein. Biochimica et Biophysica Acta, v. 1736, n. 3, p. 244-50, 2005.

KRAMER JKG, SEHAT N, DUGAN MER, MOSSOBA MM, YURAWECZ MP, ROACH JAG, et al, Distributions of conjugated linoleic acid (CLA) isomers in tissue lipid classes of pigs fed a commercial CLA mixture determined by gas chromatography and silver ion-high performance liquid chromatography. Lipids, v. 33, p. 549-558, 1998.

KO Y.H., JANG I. S, YANG H.Y. Effect of Conjugated Linoleic Acid on Intestinal and Hepatic Antioxidant Enzyme Activity and Lipid Peroxidation in Broiler Chickens. AsianAustralasian Journal of Animal Sciences, v. 17, n. 8, p. 1162-1167, 2004.

LATOUR, M. A., E. D. PEEBLES, C. R. BOYLE, J. D. BRAKE, AND T. F. KELlOGG, Changes in serum lipid, lipoprotein and corticosterone concentrations during neonatal chick development. Biology of the Neonate, v. 67, p. 381-386, 1995.

LATOUR, M. A., E. D. PEEBleS, S. M. DOYLE, T. PANSKY, T. W. SMITH; C. R. BOYLE. Broiler breeder age and dietary fat influence the yolk fatty acid profiles of fresh eggs and newly hatched chicks. Poultry Science, v. 77, p. 47-53, 1998.

LATOUR M.A., DEVITT A.A., MEUNIER R.A., STEWART J.J., WATKINS B.A. Effects of Conjugated Linoleic Acid. 1. Fatty Acid Modification of Yolks andNeonatal Fatty Acid Metabolism. Poultry Science, v. 79, p. 817-821, 2000.

Ledvinka, Z. ; Zita, L. ; Hubený, M. ; Tumová, E. ; Tyller, M. ; Dobrovolný, P. ; Hruška, M. Eff ect of genotype, age of hens and $\mathrm{K} / \mathrm{k}$ allele on eggshell quality. Czech Journal of Animal Science, v.56, n. 5, p. 242-249, 2011.

LEHNINGER, A.L.; DAVID, L.N.; MICHAEL, M.C. Lehninger principles of biochemistry.3. Ed. São Paulo.SARVIER, 2002. 975p.

LEONE V.A., AYDIN R., COOK M.E, STRANSKY D.L. Evidence for conjugated linoleic acid-induced embryonic mortality that is independent of egg storage conditions and changes in egg relative fatty acids. Poultry Science, v. 88, p. 1858-1868, 2009.

LEUNG, Y.H.; LIU R.H. Trans-10, cis-12-conjugated linoleic acid isomer exhibits stronger oxyradical scavenging capacity than cis-9,trans 11-conjugated linoleic acid isomer. Journal of Agricultural and Food Chemistry, v. 48, p. 5469-5475, 2000.

LIMA, E.S.; ABDALLA, D.S.P. Peroxidação lipídica: mecanismos eavaliação em amostras biológicas. Revista Brasileira de Ciências Farmacêuticas, v. 37, n. 3, p. 293-303, set/dez. 2001. 
LOPES, D.C.; SANTANA, M.C.A. Determinações de proteínas em alimentos para animais: métodos químicos e físicos. Viçosa: Ed. UFV, 2005. 98p

MACARI, M; FURLAN, R., L.; GONZALES, E. Fisiologia aviária aplicada frangos de corte. $2^{\text {a }}$ ed. Jaboticabal: FUNEP/UNESP, 2002. 375p.

MACARI, M.; GONZALES, E.; MARTINS, P.C.; NÄÄS, I.A.; PATRÍCIO, I.S. Manejo da Incubação. 3 ed. Jaboticabal: FACTA, 2013. 468p

MAZZUCO, H. Ovo: alimento funcional, perfeito à saúde. Avicultura Industrial, v. 99, n. 1164, p. 12-16, 2008

MEIJERHOF, R. Pre-Incubation holding of hatching eggs. World's Poultry Science Journal, v. 48, p. 57-68, 1992.

MEIJERHOF, R. Chick size matters. World's Poultry Science Journal, v. 22, n. 5, 2006.

MEIJERHOF, R. The influence of incubation on chick quality and broiler performance. p.167-170, 20 ${ }^{\circ}$ Annual Australian Poultry Science Symposium,. Sydney, NSW, Australia, 2009.

MIKEC, M.; BIDIN, Z.; VALENTIC, A.; SAVIC, V.; AMSEL ZELENIKA, T.; RAGUZDURIC R.; LUKAE, I; NOVAK; BALENOVIC, M. Influence of environmental and nutritional stressors on yolk sac utilization, development of chicken gastrointestinal system and its imune status. World's Poultry Science Journal, v. 62, p. 31-40, 2006.

MIYAZAWA T.; TSUZUKI T.; NAKAGAWA K.; IGARASHI M. Fatty acids with conjugated unsaturation: relationship between oxidative stability and physiological activities. Lipid Technology, v. 17, p. 221-, 2005.

MUMA E.; PALANDER S.; NASI M.; PFEIFFER A. M.; KELLER T.; GRIINARI J. M., Modulation of conjugated linoleic acid-induced loss of chicken egg hatchability by dietary soybean oil. Poultry Science, v. 85, p. 712-720, 2006.

NASCIMENTO, V. P.; SALLE, C. T. P. O ovo. In: MACARI, M.; GONZALES, E. Manejo da incubação. 2. ed.. Campinas: Fundação APINCO de Ciência e Tecnologia Avícolas, p.3450,200 .

NOBLE, R. C.; SHAND. J. H. Unsaturated fatty acid compositional changes and desaturation during the embryonic development of the chicken. Lipids, v. 20, p. 278-282, 1985.

NOBLE, R. C. E D. OGUNYEMI. Lipid changes in the residual yolk and liver of the chick immediately after hatching. Biology of the Neonate, v. 56, p. 228-236, 1989.

NOBLE, R. C.; M. COCCHI. Lipid metabolism and the neonatal chicken. Progress in Lipid Research, v. 29, n. 2, p.107-140, 1990.

NOY, Y.; D. SKLAN. 1999. Energy utilization in newly hatched chicks. Poultry Science, v. 78, p. 1750-1756. 
NYS Y., GAUTRON J., GARCIA-RUIZ J.M., HINCKE M.T. Avian eggshell mineralization: biochemical and functional characterization of matrix proteins. Comptes Rendus Palevol, v. 3, p. 549-562, 2004.

OLIVEIRA, B.L.de; OLIVEIRA, D.D.de. Qualidade e tecnologia de ovos. Lavras: Ed. UFLA, 2013. 224p.

OHTSU, H. ; SATO, K. ; NISHIDA, H. ; AKIBA, Y. High $\beta$-hydroxybutyrate concentration in liver and skeletal muscle of newly hatched chicks. Comparative Biochemistry and Physiology, v.134, p. 3, p. 625-629, 2003.

PARIZA M. W.; PARK Y.; COOK M. E. The biologically active isomers of conjugated linoleic acid. Progress in Lipid Research, v. 40, n. 4, p. 283-98, 2001.

PARK Y.; PARIZA M.W. Mechanisms of body fat modulation by conjugated linoleic acid (CLA). Food Research International, v. 40, p. 311-323, 2007.

PARK Y.; STORKSON J. M.; NTAMBI J. M.; COOK M. E. SIH C. J., PARIZA M. W. Inhibition of hepatic stearoyl-CoA desaturase activity by trans-10, cis-12 conjugated linoleic acid and its derivatives. Biochimica et Biophysica Acta, v. 1486, n 2-3, p. 285-92, 2000.

PEEBLES, E D ; LI, L ; MILLER, S ; PANSKY, T ; WHITMARSH, S ; LATOUR, M A ; GERARD, P D. Embryo and yolk compositional relationships in broiler hatching eggs during incubation. Poultry Science, v.78, n. 10, p.1435-42, 1999.

POWELL, K. ; DEANS, E. ; SPEAKE, B. Fatty acid esterification in the yolk sac membrane of the avian embryo. Journal of Comparative Physiology, v. 174, n. 2, p.163-168, 2004.

REIS L. H.; GAMA L. T., SOARES M. C. Effects of short storage conditions and broiler breeder age on hatchability, hatching time, and chick weights Poultry Science, v. 76, n. 11, p. 1459-1466, 1997.

REIJRINK I. A. M., BERGHMANS D., BRAND H. van den, KEMP B., MEIJERHOF R. Influence of egg storage time and preincubation warming profile on embryonic development, hatchability, and chick quality. Poultry Science, v. 89, p. 1225-1238, 2010.

ROCHA, J. S. R. Efeito da cantaxantina dietética para matrizes pesadas com idade avançada e do período de armazenamento dos ovos sobre a fertilidade, rendimento de incubação, nutrientes da gema e desenvolvimento embrionário. 2011. 80 p. [tese]. Universidade Federal de Minas Gerais, Belo Horizonte, 2011.

ROCHA, J.S.R.; LARA,L.J.C.; BAIÃO, N.C. et al. Efeito da classificação dos ovos sobre o rendimento de incubação e os pesos do pinto e do saco vitelino. Arquivo Brasileiro de Medicina Veterinária e Zootecnia, v.60, n. 4, p. 979-986, 2008.

ROLAND, D. A. Factors influencing shell quality of aging hens. Poultry Science, v. 58, p. 774-777, 1979.

ROMANOFF, A. L.; ROMANOFF, A. J. The avian egg. 2. ed. Nova York: John Wiley \& Sons, 1963. $918 \mathrm{p}$. 
ROSA P. S.; AVILA, V. S. Variáveis relacionadas ao rendimento da incubação de ovos em matrizes de frangos de corte. CT / 246 / Embrapa Suínos e Aves, p. 1-3, 2000.

ROSE-MARTEL M., DU J., HINCKE M.T. Proteomic analysis provides new insight into the chicken eggshell cuticle. Journal of Proteomics, v. 75, p. 2697-2706, 2012.

ROStagnO, H. S. (Ed.). Tabela Brasileira para Aves e Suínos. $3^{\mathrm{a}}$ ed. UFV Editora: Viçosa, MG, 2011, 252 p.

ROYAN M.; GOH Y. M.; OTHMAN F.; SAZILI A. Q.; NAVIDSHAD B. Effects of dietary conjugated linoleic acid (CLA), n-3 and n-6 fatty acids on performance and carcass traits of broiler chickens. African Journal of Biotechnology, v. 75, p. 17379-17384, 2011

ROYAN M.; MENG G. Y.; OTHMAN F.; SAZILI A. Q.; HANACHI P. Effects of dietary combination of conjugated linoleic acid with fish oil or soybean oil on fatty acid composition of broiler meat. Arch. Geflugelk, v. 77, p. 189-198, 2013.

ŞAHAN, U ; IPEK, A ; SOZCU, A. Yolk sac fatty acid composition, yolk absorption, embryo development, and chick quality during incubation in eggs from young and old broiler breeders. Poultry Science, v. 93, n. 8, p. 2069-2077, 2014.

SALDANHA E.S.P.B. Efeitos de minerais orgânicos no desempenho, qualidade de ovos e qualidade óssea de poedeiras semi-pesadas no segundo ciclo de produção [tese]. Botucatu (SP): Universidade Estadual Paulista, 2008.

SANTOS, M. S. V; ESPÍNDOLA, G.B; LÔBO, R. N. B.; FREITAS, E. R.; José Lúcio Lima GUERRA, J. L. L.; SANTOS, A. B. E. Effect of temperature and storage of eggs. Ciência e Tecnologia de Alimentos, v. 29, n. 3, p. 513-517, 2009.

SANTOS-ZAGO L. F., BOTELHO A. P., REIS S. M. P. M., OLIVEIRA A. C. Isomers characterization and autoxidation stability of two conjugated linoleic acid (CLA) supplements. Anais do $4^{\circ}$ Euro Fed Lipid Congress, Madri, Espanha, 2006.

SAS Institute Inc. 1989. A user's guide to SAS. SAS Institute Inc. Cary, NC.

SCOTT, T. A.; SILVERSIDES, F. G.The effect of storage and strain of hen on egg quality. Poultry Science, v. 79, p. 1725-1729, 2000.

SHAND, J. H.; WEST D.W.; MCCARTNEY R. J.; NOBLE R. C.; SPEAKE, B. K.The esterification of cholesterol in the yolk sac membrane of the chick embryo. Lipids, v. 28, p. 621-625, 1993.

SHANG, X. G., WANG F. L.; LI D. F., YIN J. D.,; LI J. Y. Effects of conjugated linoleic acid on the productivity of laying hens and egg quality during refrigerated storage. Poultry Science, v. 83, p. 1688-1695, 2004

SILVA, D.J.; QUEIROZ. A, C. de. Análise de Alimentos: métodos químicos e biológicos. Viçosa, MG: UFV, 235p. 2002. 
SILVERSIDES, F. G.; SCOTT, T. A. Effect of storage and layer age on quality of eggs from two lines of hens. Poultry Science, v. 80, p. 1240-1245, 2001.

SINDIRAÇÕES. Compêndio Brasileiro de Alimentação Animal. Ed. Sindicato Nacional da Indústria de Alimentação Animal. São Paulo, SP, 2005, 204p.

SKLAN, D.; HEIFETZ, S.; HALEVY, O. Heavier chicks at hatch improves marketing body weight by enhancing skeletal muscle growth. Poultry Science, v. 82, p. 1778-1786, 2003.

SOUZA, T. C. Estabilidade oxidativa da carne de frango pré-cozida contendo bioprodutos do cerrado. Faculdade de Agronomia e Medicina Veterinária da Universidade de Brasília, Brasília, 40 p., 2013.

SPEAKE, B. K..; NOBLE, R. C.; MCCARTNEY R. J. Tissuespecific changes in lipid composition and lipoprotein lipase activity during the development of the chick embryo. Biochimica et Biophysica Acta, v. 1165, p. 263-270, 1993.

SPEAKE, B. K.; MURRAY, A. M. B.; NOBLE, R.C. Transport and transformation of yolk lipids during development of the avian embryo. Progress in Lipid Research. v. 37, p. 1-32, 1998.

SPEAKE, B. K.; WOOD.N. A. R. Timing of incorporation of docosahexaenoic acid into brain and muscle phospholipids during precocial and altricial modes of avian development. Comp. Biochem. Physiol. B Biochem. Mol. Biol., v. 141, p. 147-158, 2005.

STANGLE, G. High dietary levels of a conjugated linoleic acid mixture alter hepatic glycerophospholipid-carrying serum lipoproteins of rats. The Journal of Nutritional Biochemistry, v. 11, p.184-191, 2000.

STEVENS, L. Egg proteins: what are their functions. Science Program, v. 79, p. 65-87, 1996

SUKSOMBAT W.; LOUNGLAWAN P.; SAMITAYOTIN S. Effects of Conjugated Linoleic Acid Supplementation in Layer Diet on Fatty Acid Compositions of Egg Yolk and Layer Performances. Poultry Science, v. 85, p. 1603-1609, 2006.

SURAI P. F., NOBLE R. C., BRIAN K. SPEAKE A. Tissue-specific differences in antioxidant distribution and susceptibility to lipid peroxidation during development of the chick embryo. Biochimica et Biophysica Acta 1304, 1-10, 1996.

TIERZUCHT, L. Manegement Guide: Hatchery, 2011.

TONA, K.; BAMELIS F.; KETELAERE, B. de; BRUGGEMAN, V.; MOREAS, V. M. B.; BUYSE, J.; ONAGBESAN, O.; DECUYPERE, E. Effects of egg storage time on spread of hatch, chick quality, and chick juvenile growth. Poultry Science, v. 82, p.736-741, 2003.

TONA, K. O. Onagbesan, B. De Ketelaere, E. Decuypere, and V. Bruggeman.Effects of age of broiler breeders and egg storage on egg quality, hatchability, chick quality, chick weight, and post-hatch growth to forty-two days. The Journal of Applied Poultry Research, v. 13, p. $10-18,2004$. 
VAN ELSWYK, M.; HARGIS, B.; WILLIAMS, J.; HARGIS, P. Dietary menhaden oil contributes to hepatic lipidosis in laying hens. Poultry Science, v. 73, p. 653-662, 1994.

VENGLOVSKA K., GRESAKOVA L., PLACHA I., RYZNER M., COBANOVA K Effects of feed supplementation with manganese from its different sources on performance and egg parameters of laying hens. Czech Journal of Animal Science, v. 59, p. 147-155, 2014.

VÉRAS, A. L. et al. Avaliação da qualidade interna de ovos armazenados em dois ambientes em diferentes tempos. Conferencia APINCO de Ciência e Tecnologia Avícolas. Trabalhos de Pesquisa Avícola. São Paulo. Brazilian Journal Poultry Science, supl. Prêmio Lamas, p. 55, 1999.

XAVIER, I. M. C. Qualidade funcional de ovos de consumo submetidos a diferentes condições de armazenamento. [Tese] (Mestrado em Medicina Veterinária) - Escola de Veterinária, Universidade Federal de Minas Gerais, 44p. Belo Horizonte, 2006.

WATKINS, B. A.; FENG, S.; STROM, A. K.; DEVITT, A. A.; YU, L.; LI, Y. Conjugated linoleic acids alter the fatty acid composition and physical properties of egg yolk and albumen. Journal of Agricultural and Food Chemistry, v. 51, p. 6870-6876, 2003.

WILLEMSEN, H.; EVERAERT, N.; WITTERS, A.; DE SMIT, L.; DEBONNE, M.; VERSCHUERE, F.; GARAIN, P.; BERCKMANS, D.; DECUYPERE, E.; BRUGGEMAN. V. Critical assessment of chick quality measurements as an indicator of posthatch performance. Poultry Science, v. 87, p. 2358-2366, 2008.

YADGARY, L.; UNI, Z. Yolk sac carbohydrate levels and gene expression of key gluconeogenic and glycogenic enzymes during chick embryonic development. Poultry Science, v..91, n. 2, p. 444-453, 2012.

YALÇIN, S.; BAĞDATLIOĞLU, N.; BRUGGEMAN, V.; BABACANOĞLU, E.; UYSAL, I.; BUYSE, J.; DECUYPERE, E.; SIEGEL, P.B. Acclimation to heat during incubation. 2. Embryo composition and residual yolk sac fatty acid profiles in chicks. Poultry Science, v. 87, p. 1229-1236, 2008.

ZANINI S.F.; VICENTE E.; COLNAGO G.L.; PESSOTTI B.M.S.; SILVA M.A. Manipulation of the fatty acids composition of poultry meat and giblets by dietary inclusion of two oil sources and conjugated linoleic acid. Arquivo Brasileiro de Medicina Veterinária e Zootecnia, v. 60, p. 1388-1398, 2008. 
CAPÍtulo 3 
RESUMO

\title{
INCLUSÃO DO CLA NA DIETA DE MATRIZES DE CORTE E TEMPOS DE ARMAZENAMENTO DE OVOS INCUBÁVEIS SOBRE O RENDIMENTO DA INCUBAÇÃO E QUALIDADE DA PROGÊNIE
}

\author{
DISCENTE: PRISCILA SOARES SILVÉRIO ${ }^{1}$ \\ ORIENTADORA: Prof ${ }^{\mathrm{a}}$. Dra ${ }^{\mathrm{a}}$. ALINE MONDINI CALIL RACANICCI ${ }^{1}$ \\ ${ }^{1}$ Universidade de Brasília - UNB
}

Foi conduzido um experimento para avaliar o efeito da inclusão dos isômeros cis-9, trans-11 e trans-10, cis-12 de ácido linoléico conjugado (CLA) na dieta de matrizes pesadas e do armazenamento dos ovos incubáveis durante três, seis e nove dias na sala de ovos do incubatório. Os tratamentos foram definidos pelas dietas (com inclusão de 0,023\% de CLA ou sem CLA) oferecidas para um total de 22.000 matrizes pesadas da linhagem Cobb® em fase de postura com idades entre 58 e 60 semanas e os tempos de armazenamento (três, seis e nove dias). Foram utilizados 1.152 ovos por tratamento divididos em 12 bandejas (repetições com 96 ovos cada) de incubação, distribuídas em um delineamento inteiramente casualisado em um esquema fatorial $2 \times 3$ (com ou sem inclusão ou não de CLA nas dietas das matrizes x 3 períodos de armazenamento). Após passarem pelos diferentes períodos de armazenamento (três, seis e nove dias), os ovos foram incubados no mesmo dia em incubadora de múltiplo 
estágio. Foram realizadas as avaliações de ovoscopia e embiodiagnóstico para determinação das fases da mortalidade embrionária (inicial, média e tardia), além da perda de peso ao armazenamento, fertilidade, taxa de eclosão, eclodibilidade, mortalidade embrionária e suas causas, parâmetros físicos de qualidade dos pintos de um dia, qualidade dos umbigos dos pintos recém-eclodidos. Após a eclosão foi realizada a morfometria dos órgãos, avaliando os pesos do fígado, pâncreas, intestinos e saco vitelino e o comprimento dos intestinos em uma amostra de 35 pintos/tratamento. Nas amostras coletadas do saco vitelino foram realizadas analises de oxidação dos lipídios através da metodologia de TBARS. Os dados obtidos foram analisados adotando um modelo misto, com efeito fixo para os tratamentos e aleatórios para os períodos de armazenamento e as médias foram comparadas pelo teste de Tukey com significância de 5\%. Foi observado que os maiores períodos de armazenamento prejudicaram os parâmetros de eclodibilidade e qualidade dos pintos, no entanto, a inclusão do CLA na dieta das matrizes pesadas apresentou efeitos positivos somente para os ovos armazenados por nove dias, reduzindo os danos oxidativos aos lipídios durante o processo de armazenamento.

Palavras-chave: CLA, armazenamento, rendimento de incubação, qualidade dos pintos, morfometria dos órgãos, TBARS saco vitelino, oxidação das gemas, oxidação lipídica. 


\begin{abstract}
INCLUSION OF CLAIN BROILER BREEDERS HENS FED DIET AND TIMES OF HATCHING EGGS STORAGE ON INCUBATION YIELD AND QUALITY OF PROGENY
\end{abstract}

\author{
GRADUATE STUDENT: PRISCILA SOARES SILVÉRIO ${ }^{1}$ \\ ADVISOR: PhD. Dr'. ALINE MONDINI CALIL RACANICCI ${ }^{1}$ \\ ${ }^{1}$ University of Brasília - UNB
}

An experiment were conducted to evaluate the effect of the inclusion of cis-9, trans-11 and trans-10, cis-12 conjugated linoleic acid isomers (CLA) in the diet of broiler breeders and storage of hatching eggs during three, six and nine days in the hatchery egg room. The treatments were defined by breeders diets (with the inclusion of 0,023\% CLA or without CLA) offered total of 22.000 broiler breeders Cobb® 58 and 60 weeks during laying phase and the storage periods (three, six nine days). Were used1.152 eggs per treatment were distributed in a complete randomized design to 12 trays (repetitions with 96 eggs per tray) for incubation, distributed in a completely randomized in a $2 \times 3$ factorial (with or without the inclusion or not of CLA in the diets $\mathrm{x} 3$ storage periods). After passing through the different periods of storage (three, six and nine days), the eggs were incubated at the same time in a multi-stage incubator. Candling and embryo evaluations were conducted to determine the 
stages of embryo mortality (early, middle and late), the weight loss during storage, fertility, hatching rate, hatchability, embryo mortality and physical parameters of quality of one-day chicks, quality of navels of newly hatched chicks. After hatching, morphometry of the organs was performed din 35 birds per treatment by assessing liver weights, pancreas, intestines, and yolk sac, and the length of intestines. Lipid oxidation was performed in the yolk sac collected from newly hatched chicks using TBARS method. Data were analyzed using a mixed model with fixed effects for treatment and random to storage periods and the averages were compared by Tukey test (5\% significance). It was observed that longer storage periods damaged the parameters of hatchability and quality of the chicks, however, dietary CLA showed positive effects on eggs stored for nine days, and reduced oxidative damage to lipids during the storage process.

Keywords: CLA, storage, incubation yield, chick quality, morphometry of the organs, TBARS of the yolk sac, yolks oxidation, lipid oxidation. 


\section{INTRODUÇÃO}

O CLA é um conjunto de isômeros posicionais geométricos do ácido linoléico (18:2n-6) (EFSA, 2016; Aydin \& Cook, 2009) e possui atividade antioxidante (Stangle, 2000; Du et al., 2001; Joo et al., 2002; Ko et al., 2004), anticancerígena (Basu et al., 2000; Kilian et al., 2002) e redutor da gordura corporal (Leung \& Liu, 2000; Park \& Pariza, 2007) possui seus efeitos estudados também na avicultura e produção de pintos.

A capacidade do CLA de diminuir a peroxidação lipídica pode ser associada à sua capacidade de afetar o sistema de defesa antioxidante (Ko et al., 2004). Leung \& Liu (2000) relataram que o isômero t-10, c-12 mostrou maior capacidade de eliminação de radicais livres com propriedades antioxidantes e o c-9, t-11 pró-oxidantes, o que explica a sua atividade anticancerígena (Basu et al., 2000; Kilian et al., 2002).

Na primeira semana de incubação, a energia metabólica utilizada pelo embrião é obtida através da glicólise anaeróbica (Moran, 2007) do albúmen menos denso (Kucera et al. 1984). Com a formação da membrana corioalantóide, que reveste a superfície interna da membrana da casca (Deeming, 2002), surge o acesso ao $\mathrm{O}_{2}$ e inicia-se a combustão completa dos ácidos graxos da gema tornando-se fonte primária de energia (Moran, 2007; Meijerhof, 2009). A membrana do saco vitelino que é bem desenvolvida e altamente vascularizada é responsável pela absorção dos lipídios da gema que, em sua maioria, é composto por triglicerídeos e fosfolipídios (Noble \& Shand, 1985).

Armazenamentos prolongados produzem efeitos negativos na qualidade dos pintinhos (Tona et al., 2003), aumenta a mortalidade embrionária inicial e final quanto 
maiores os tempos de armazenamento (Fasenko et al., 2001) pois ocasiona a morte celular no embrião (Fasenko et al., 2001; Fasenko, 2007) e compromete a qualidade do pinto recémnascido o que é determinante para sua sobrevivência, crescimento e saúde (Willemsen et al., 2008). Nos incubatórios comerciais, os parâmetros físicos de avaliação dos pintos são utilizados para classificar os pintos (Reijrink et al., 2010), mas outros também são importantes para avaliar a qualidade do pintinho, como o peso corporal livre de gema e os índices morfométricos (Sahan, 2014).

O objetivo deste estudo foi avaliar os efeitos da adição do ácido linoléico conjugado (CLA) nas dietas de matrizes pesadas e do tempo de armazenamento na sala de ovos sobre os aspectos relacionados à viabilidade da incubação, eclodibilidade, mortalidade embrionária, qualidade dos pintos e oxidação dos lipídios da gema e do saco vitelino. 


\section{MATERIAL E MÉTODOS}

\subsection{Incubação}

Antes da incubação os ovos passaram por um pré-aquecimento com temperatura média de $26^{\circ} \mathrm{C}$ e umidade relativa média de $76 \%$ durante 8 horas, conforme o procedimento padrão da empresa.

Os ovos de todos os tratamentos foram incubados no mesmo dia em incubadora de múltiplo estágio marca CASP (modelo $\mathrm{CMG}_{2} 25_{\mathrm{R}}$ ) com capacidade para 124.416 ovos e sistema de viragem das bandejas a cada uma hora, regulada para temperatura média de $37,4^{\circ} \mathrm{C}$ e umidade relativa entre 55 e $60 \%$.Para minimizar as variações de temperatura e umidade dentro da incubadora, os ovos do experimento foram alocados no espaço central das fileiras de bandejas, sendo utilizadas as bandejas de numeração 8 e 11 da incubadora, cada uma com capacidade para 2 bandejas de 96 ovos cada, que foram distribuídas em blocos nos dois lados da incubadora, que possui 18 fileiras de bandejas cada lado (Fig. 3.1). 

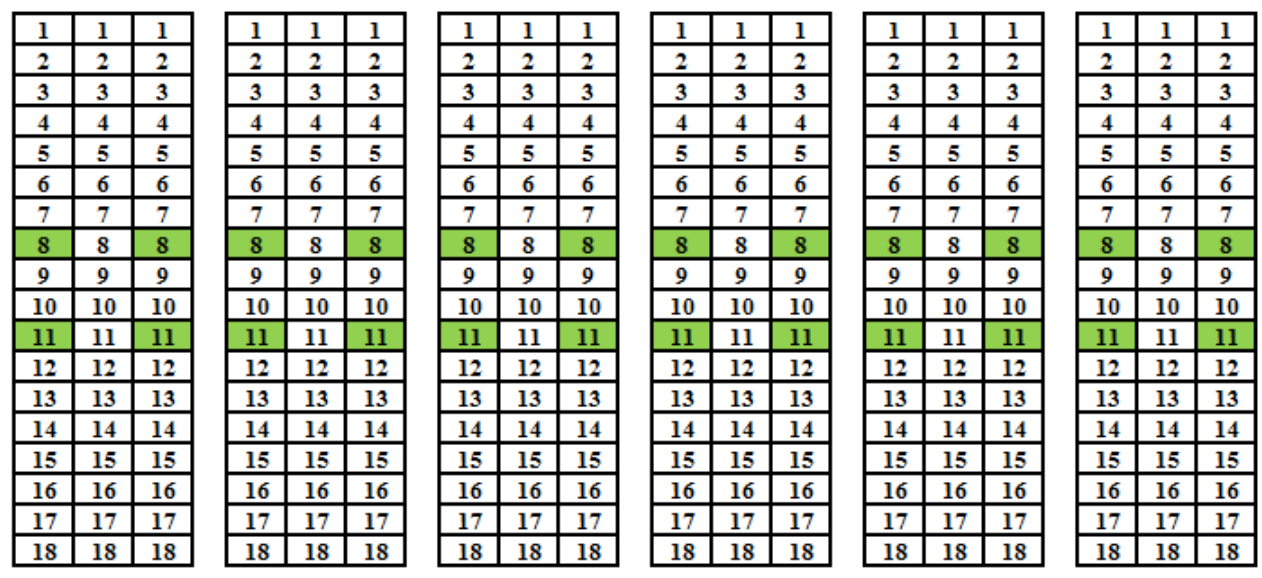

Figura 3.1 Esquema de utilização das bandejas de incubação em uma das laterais da incubadora. Foram utilizados os dois lados da incubadora neste mesmo esquema.

\subsection{Ovoscopia}

O procedimento de ovoscopia foi realizado aos 13 dias de incubação em todos os ovos incubados do experimento (1.152 ovos/trat e 6.912 ovos no total). As bandejas de incubação foram colocadas no ovoscópio (Fig. 3.2) e o procedimento foi realizado dentro da própria incubadora (Fig. 3.3), para evitar prejuízos ao desenvolvimento embrionário. Após a avaliação e retirada dos ovos inférteis, as bandejas devidamente identificadas foram realocadas em suas posições iniciais na incubadora. Vale ressaltar que as lacunas dos ovos retirados não foram preenchidas, como seria o procedimento normal do incubatório, a fim de evitar erros experimentais.

Os ovos inférteis (ou claros) foram retirados das bandejas de incubação e devidamente identificados, sendo levados para área suja do incubatório para análise de mortalidade embrionária. Um a um, foram quebrados e avaliados quanto aos parâmetros de infertilidade, presença de contaminações, trincados, ocorrência de mortalidade embrionária inicial (0 a 7 dias) e intermediária (8 a 14 dias), segundo Cobb (2013).

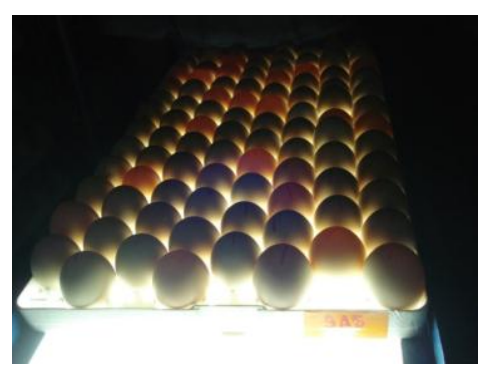

Figura 3.2 Ovoscopia de bandeja experimental

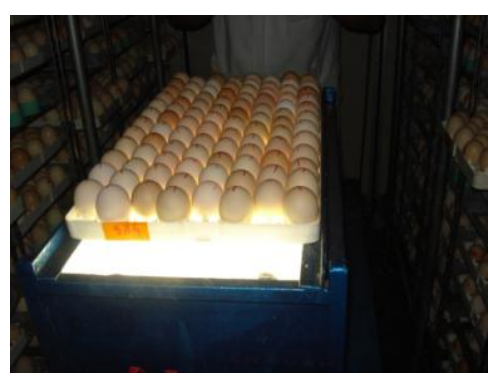

Figura 3.3 Ovoscópio dentro da incubadora 


\subsection{Transferência da incubadora para o nascedouro}

A transferência dos ovos da incubadora para as máquinas de nascedouro ocorreu após 18 dias de incubação. O procedimento de vacinação "in ovo" não foi realizado para minimizar possíveis danos aos ovos do experimento. As bandejas foram retiradas da incubadora e os ovos transferidos para bandejas de eclosão (Fig.3.4) devidamente identificadas. Todos os ovos do experimento foram alocados no mesmo nascedouro (Fig. 3.5) e as bandejas dispostas aleatoriamente na máquina (marca CASP, modelo G21) com capacidade para 20.736 ovos, com temperatura interna média de $36,8^{\circ} \mathrm{C}$ e umidade relativa entre 60 a $65 \%$.

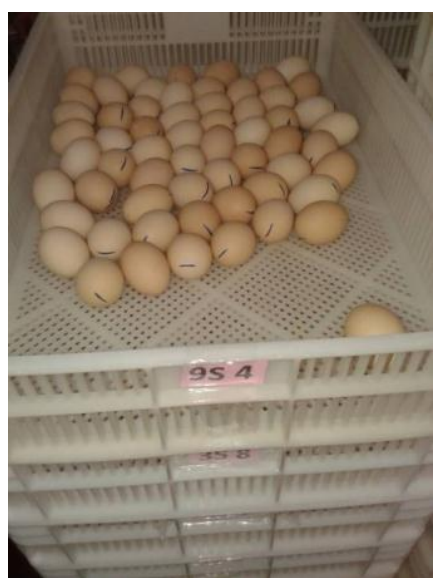

Figura 3.4 Bandejas de eclosão

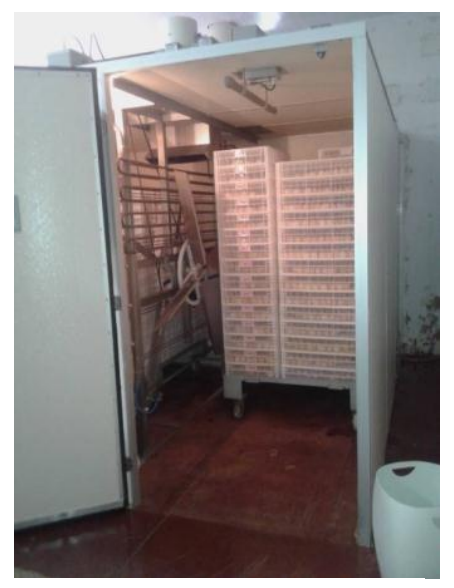

Figura 3.5 Nascedouro com ovos experimentais

\subsection{Nascimento dos pintos}

O nascimento e retirada dos pintos das gavetas do nascedouro ocorreu após 21 dias de incubação. Os pintos foram transferidos das gavetas do nascedouro (Fig. 3.6) para as bandejas de nascimento (Fig. 3.7), devidamente identificadas, dispostas em carrinhos e encaminhadas à sala de pintos (temperatura média de $24,3^{\circ} \mathrm{C}$ e $65 \%$ de umidade relativa).

Os pintos foram sexados, contados, pesados, classificados de acordo com a cicatrização umbilical e os mortos pós-eclosão foram separados. Os pintos não foram vacinados a fim de evitar manipulação e possíveis erros no processo. Trinta e cinco pintos machos de cada tratamento (210 animais ao todo) foram coletados aleatoriamente, dispostos em caixas de transporte e encaminhados ao Laboratório de Nutrição Animal da Universidade de Brasília, na Fazenda Água Limpa, localizada no Núcleo Rural Vargem Bonita - Distrito 
Federal, para pesagem individual e realização de eutanásia para a realização da morfometria dos órgãos.

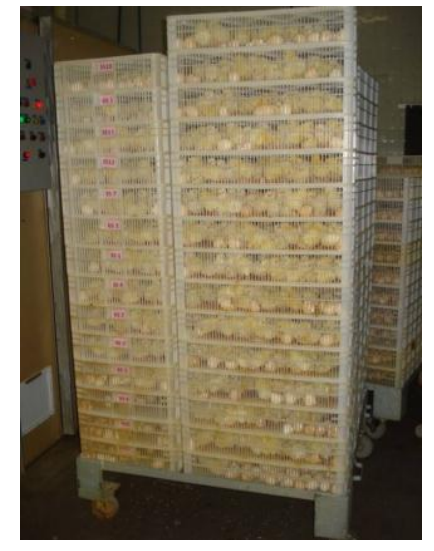

Figura 3.6 Pintos em gavetas do nascedouro

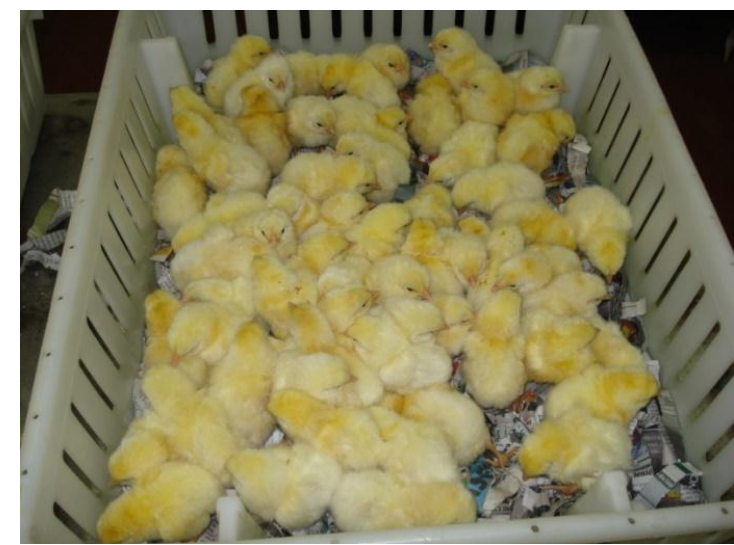

Figura 3.7 Gavetas de nascimento

\subsection{Embriodiagnóstico}

O embriodiagnóstico foi realizado no dia do nascimento dos pintos a partir da quebra de todos os ovos não eclodidos para estimativa da mortalidade embrionária em cada fase de desenvolvimento, sendo considerados: ovos com embriões que morreram entre 0 a 7 dias; 8 a 14 dias e 15 a 21 dias de incubação, ovos bicados com embriões vivos e mortos; contaminados, desidratados, embriões com posicionamento incorreto da cabeça, embriões posicionados de forma invertida em relação ao ovo e má formação embrionária (cérebro exposto, cavidade abdominal aberta e membro duplicado).

\subsection{Parâmetros de incubação e desempenho da progênie}

Foram avaliados os efeitos da adição do CLA e do tempo de armazenamento sobre a perda de peso dos ovos, a fertilidade, as taxas de eclosão, eclodibilidade e a mortalidade embrionária, assim como a qualidade dos pintos de um dia.

Cada tratamento possui 12 repetições, sendo o número de bandejas utilizadas na incubadora por tratamento. Em cada bandeja, incubou-se 96 ovos (1.152 ovos/trat), totalizando 6.912 ovos. 
4.6.1 Perda de peso do ovo durante armazenado em diferentes períodos na sala de ovos (PPO)

A perda de peso dos ovos foi avaliada durante o armazenamento com diferentes tempos (3, 6 e 9 dias), sendo as bandejas vazias pesadas antes e após receberem os ovos no dia da coleta, e as bandejas com ovos pesadas novamente no dia da incubação. A perda de peso foi calculada pela diferença de peso das bandejas no dia do recebimento dos ovos e no dia da incubação.

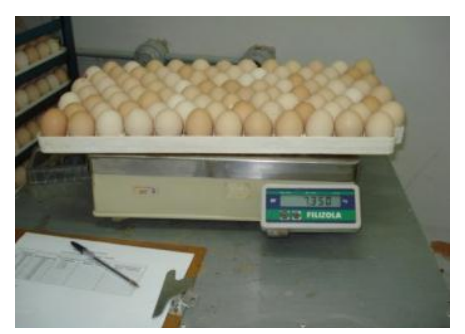

Figura 3.8 Pesagem das bandejas no incubatório

4.7 Rendimento de incubação e mortalidade embrionária

\subsubsection{Fertilidade (FERT)}

A fertilidade foi avaliada em dois períodos: aos 13 e 21 dias de incubação. No $13^{\circ}$ dia de incubação, todos os ovos passaram por ovoscopia, sendo retirados os ovos inférteis e aqueles com embriões mortos. Ao final dos 21 dias de incubação, todos os ovos não eclodidos foram quebrados para realização do embriodiagnóstico e os ovos inférteis remanescentes também foram mensurados.

\subsubsection{Taxa de eclosão (TXEC)}

A taxa de eclosão foi estimada com relação ao número total de ovos incubados. Foi calculada tendo como base o número de pintos nascidos em relação ao número total de ovos incubados. 


\subsubsection{Eclodibilidade (ECL)}

A taxa de eclodibilidade foi estimada com relação ao número total de ovos férteis. Foi calculada tendo como base o número de pintos nascidos em relação ao número total de ovos férteis.

\subsubsection{Mortalidade embrionária total (MET)}

O índice de mortalidade embrionária, bem como a fertilidade, foi avaliado aos 13 e 21 dias de incubação através dos procedimentos de ovoscopia e embriodiagnóstico, respectivamente. A mortalidade embrionária foi classificada de acordo com as fases do desenvolvimento embrionário ocorrido entre 0 a 7; 8 a 14 e 15 a 21 dias de incubação, ovos bicados com embriões vivos e mortos. As causas de mortalidade também foram avaliadas com os parâmetros: embriões contaminados, desidratados, embriões com posicionamento incorreto da cabeça (P1), embriões posicionados de forma invertida ao polo do ovo (P2) e má formação embrionária - A1 (cérebro exposto, cavidade abdominal aberta e membro duplicado).

As taxas de mortalidade embrionária foram calculadas pela razão entre os pintos não eclodidos em determinada faixa de idade e os ovos férteis, com relação ao total de ovos incubados (Cobb, 2013).

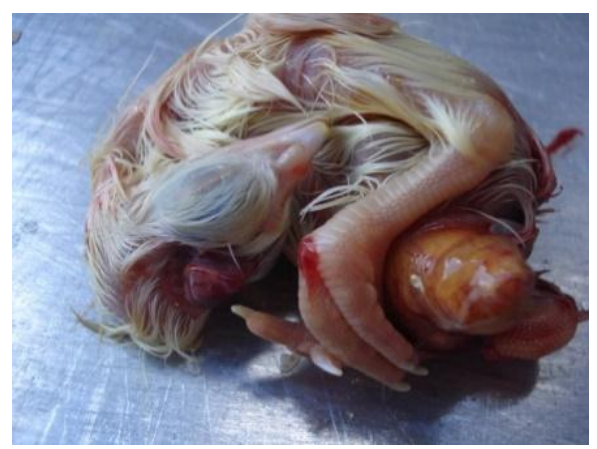

Figura 3.9 Embrião A1 - cérebro exposto 
4.8 Parâmetros físicos de qualidade dos pintos de um dia

As avaliações dos parâmetros físicos de qualidade dos pintos foram realizadas na sala de pintos do incubatório comercial e foram observadas: a qualidade dos umbigos dos neonatos, a classificação visual dos pintos, sendo divididos em: pintos de $1^{\mathrm{a}}$ linha $\left(1^{\mathrm{a}} \mathrm{L}\right.$ plumagem limpa, olhos brilhantes, canelas hidratadas e umbigo cicatrizado), de $2^{\mathrm{a}}$ linha ( $2^{\mathrm{a}} \mathrm{L}$ plumagem suja, tamanho pequeno, abdômen rígido, articulações levemente avermelhadas, plumagem preta e umbigo não cicatrizado) e eliminados (ELIM- aleijados, articulações fortemente avermelhadas, umbigo não cicatrizado, vísceras expostas e desidratados), de acordo com manual da linhagem (Cobb, 2013). Além disso, foram contabilizados os pintos mortos pós-eclosão (MPE), que foram coletados nas bandejas de nascimento após a contagem do total de nascidos.

4.8.1 Avaliação da qualidade dos umbigos dos pintos de um dia

Os umbigos foram avaliados e considerados: umbigo eliminados (UE - pintos com umbigo não cicatrizados que foram eliminados), umbigo não eliminados (UNE - umbigos não cicatrizados e não eliminados, considerados pintos de segunda linha ou de pintos de seleção e o total de umbigos que apresentaram com problemas de cicatrização).

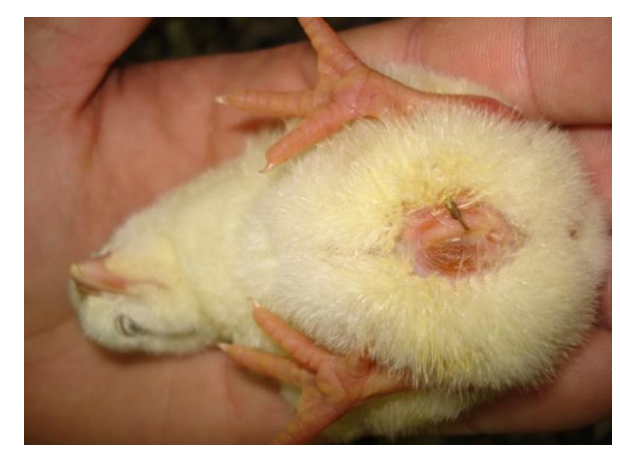

Figura 3.10 Pinto com umbigo não cicatrizado 


\subsubsection{Morfometria dos órgãos}

Após eutanásia feita por deslocamento cervical os órgãos: pro-ventrículo e moela - PPM, fígado- PF, pâncreas - PPan, saco vitelino - PSV e intestinos (PI) foram coletados separadamente em placas de petri e pesados em balança com precisão de $0,01 \mathrm{~g}$. Os intestinos foram esticados em superfície plana e suas porções foram medidas com fita métrica, considerando: comprimento do intestino total (CIT), comprimento do intestino delgado (CID) e reto $(\mathrm{CR})$.

Os pesos relativos dos órgãos foram calculados em porcentagem em relação ao peso do pinto.

\subsubsection{Peso do pinto (PP) e saco vitelino (PSV) a eclosão}

Foram usados 210 pintos recém-eclodidos (35 pintos por tratamento, sendo cada animal considerado uma repetição) para pesagem individual em balança com precisão de 0,01g, sendo eutanaziados através de deslocamento cervical para retirada do saco vitelino.

Para determinação do peso relativo do pinto foi utilizada a seguinte equação: $\operatorname{PrP}=$ (peso do pinto em g/peso inicial do ovo em g)x100 (Sahan et al., 2014). Para o cálculo do peso relativo dos órgãos foi utilizada a equação = (peso do órgão/peso do pinto) x 100.

4.9 Congelamento e liofilização das amostras de gemas e albúmen coletadas

Todos os "pools" de gemas e saco vitelino foram congelados em freezer doméstico $\left(-14^{\circ} \mathrm{C}\right.$ durante 24 horas) e submetidos à 24 horas de liofilização, tempo suficiente para retirada da maior parte da umidade (de 50\% UM para 2,5\% UM). Foi utilizado o liofilizador de bancada marca LIOTOP, modelo L101 (Fig. 3.11), sendo o processo de liofilização realizado para minimizar a oxidação lipídica e as perdas do conteúdo lipídico das gemas.

Após liofilização, as gemas foram moídas em moinho de facas com sistema de resfriamento da marca TECNAL, modelo TE 631 (Fig 3.12), posteriormente separados em potes estéreis devidamente identificados. 
As amostras de claras foram congeladas e mantidas em freezer, pois não foi possível realizar o processo de liofilização adequadamente.

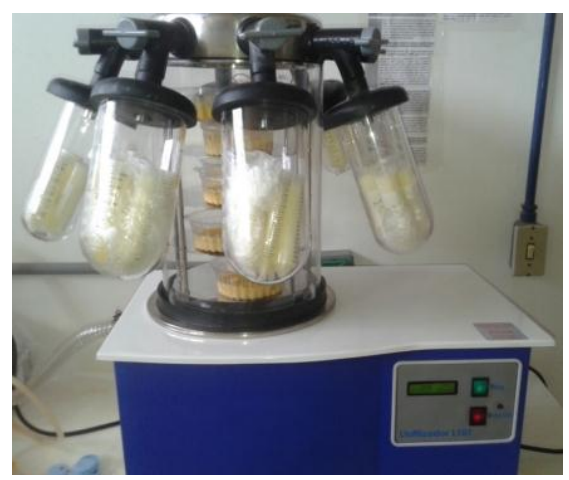

Figura 3.11 Liofilizador com amostras experimentais

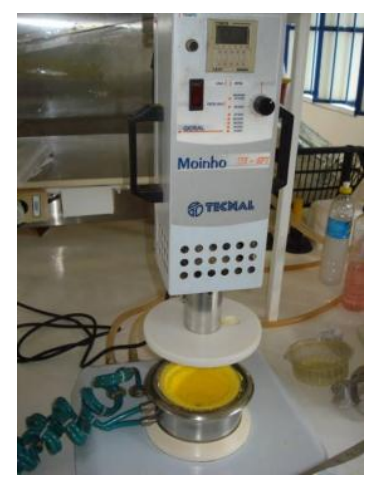

Figura 3.12 Moagem das amostras

4.10 Análise de oxidação lipídica

4.10.1 Substâncias reativas ao ácido tiobarbitúrico (TBARS)

A avaliação da oxidação lipídica foi feita através quantificação dos compostos secundários pelo método de TBARS (substâncias reativas ao ácido tiobarbitúrico) descrito por Vyncke (1970, 1975) e modificado por Sorensen \& Jorsensen (1996). As análises foram realizadas nos sacos vitelinos (TBARSS) dos pintos ao nascimento em duas repetições/tratamento.

As amostras de saco vitelino foram conservadas em geladeira por aproximadamente 12 horas, sendo posteriormente homogeneizadas em misturador UltraTurrax (13.500 rpm por $45 \mathrm{seg}$ ) com15 ml de solução de ácido tricloroacético (TCA 7,5\%), contendo $0,1 \%$ de ácido etilenodiaminotetracético (EDTA) e $0,1 \%$ de propilgalato (PG) preparada em água mili-Q.

Após filtração, foram pipetados $5 \mathrm{ml}$ em tubos de ensaio e adicionados de $5 \mathrm{~mL}$ da solução de TBA (2-thiobarbituric acid), levados à banho-maria ( $100^{\circ} \mathrm{C}$ durante $\left.40 \mathrm{~min}\right)$. Após resfriamento em banho frio foi realizada a leitura da absorbância em 532 e 600nm usando espectrofotômetro marca GEHAKA, modelo UV 340G. E Os resultados foram expressos em $\mu \mathrm{mol}$ de malonaldeídos (MDA)/kg de amostra usando uma curva padrão feita com 1,1,3,3-tetraetoxipropano ( $\left.\mathrm{y}=0,0804 \mathrm{x}+0,0077 ; \mathrm{R}^{2}=0,9999\right)$. 
4.11 Delineamento experimental e análise estatística

Os ovos foram distribuídos em blocos ao acaso, sendo considerado o bloco a posição das bandejas de ovos nos carrinhos dentro da sala de ovos e incubadora, em um esquema fatorial $2 \times 3$ (com ou sem inclusão de CLA nas dietas das matrizes x 3 períodos de armazenamento (3, 6 e 9 dias).

Para as avaliações do incubatório foram utilizadas 12 repetições por tratamento, sendo cada bandeja com 96 ovos considerada uma repetição.

$\mathrm{Na}$ avaliação de perda de peso dos ovos durante o armazenamento, utilizou-se o esquema fatorial 2x4 (CLA x tempos armazenamento), pois nesse caso, o tempo inicial do armazenamento foi considerado, ou seja, as pesagens iniciais foram realizadas nos ovos antes do armazenamento em sala de ovos.

As análises de índices de peróxidos, acidez e TBARS das gemas foram utilizadas 6 repetições/tratamento e o TBARS do sacos vitelinos foram analisados em 2 repetições/tratamento.

Os dados obtidos foram comparados adotando um modelo misto, com efeito fixo para os tratamentos e aleatórios para os períodos de armazenamento, utilizando-se o procedimento PROC MIXED do software Statistical Analisys Sistem (SAS 9.3®). As médias foram comparadas pelo teste de Tukey com significância de $5 \%$. 


\section{RESULTADOS E DISCUSSÃO}

5.1 Parâmetros de incubação e desempenho da progênie

5.1.1 Perda de peso do ovo armazenado em diferentes períodos na sala de ovos

Na Tabela 3.1 observa-se que a perda de peso do ovo (PPO) não foi afetada pela inclusão do CLA, mas sim pelo armazenamento, sendo que os ovos perderam mais peso com o aumento do tempo de armazenamento devido à maior perda de água via poros da casca, através do mesmo mecanismo de perda de $\mathrm{CO}_{2}$ (Macari et al., 2013). Os valores encontrados para PPO foram similares aos descritos por Fasenko et al. (2001), no qual ovos armazenados durante 4 e 14 dias apresentaram perda de peso de $0,15 \%$ e 1,20\%, respectivamente. Reijrink et al. (2010) verificaram ovos de matrizes entre 41 e 50 semanas armazenados sob temperatura média de $16^{\circ}$ e $18^{\circ} \mathrm{C}$ durante 4 dias perderam $0,53 \%$ menos peso durante o armazenamento quando comparados com ovos armazenados por 14 dias $(\mathrm{P}<0.001)$. Neste experimento, os ovos armazenados durante seis dias perderam $0,33 \%$ mais peso quando comparados aos armazenados por três dias, já os que passaram por maior tempo de armazenamento (nove dias) perderam 0,68\% quando comparados aos primeiros (três dias), ou seja, a velocidade de perda de peso dos ovos aumentou com a progressão dos tempos de armazenamento, conforme esperado, Santos et al. (2009) notaram que a perda de peso dos ovos armazenados por longos períodos ocorre independentemente das condições de temperatura de conservação. A perda de peso dos ovos é um indicador de fácil mensuração no incubatório e muito eficiente para avaliar se as condições de armazenamento da sala de ovos 
estão adequadas, tanto com relação à temperatura quanto para a umidade. Macari et al. (2013) citam que níveis ótimos de umidade para a sala de ovos estão situados entre 75 a $90 \%$ e quanto à temperatura, devem estar abaixo do zero fisiológico, ou seja, abaixo de $21^{\circ} \mathrm{C}$ (Fasenko, 2007). Neste experimento, as condições ambientais da sala de armazenamento dos ovos eram de $21^{\circ} \mathrm{C}$ e umidade relativa média de 76\%. Meijerhof \& Beek (1993) notaram que a perda de água do ovo é de cerca de $0,05 \%$ ao dia em longos períodos de armazenamento em baixas temperaturas, o mesmo valor encontrado neste experimento para os ovos armazenados por três dias. Já os armazenados por seis dias perderam 0,08\% de água por dia e os armazenados por maior período (nove dias) perderam 0,09\%/dia, valores semelhantes aos encontrados por Reijrink et al. (2010). A idade das matrizes pode ter influenciado também nos resultados de PPO, segundo Barbosa et al. (2012) verificaram que a qualidade das cascas dos ovos de matrizes velhas é inferior aos de matrizes mais novas, o que pode justificar maiores perdas de peso dos ovos de matrizes mais velhas.

Tabela 3.1 Valores médios do peso inicial $\left(\mathrm{PO}_{\mathrm{i}}\right)$ e perda de peso percentual $(\mathrm{PPO}, \%)$ dos ovos armazenados durante 3, 6 e 9 dias com e sem inclusão de CLA

\begin{tabular}{ccc}
\hline Tratamentos & $\mathrm{PO}_{\mathrm{i}}$ & $\mathrm{PPO}$ \\
\hline C/CLA & 68,74 & 0,47 \\
S/ CLA & 68,60 & 0,49 \\
Arm3 & 68,82 & $0,14^{\mathrm{C}}$ \\
Arm6 & 68,52 & $0,47^{\mathrm{B}}$ \\
Arm9 & 68,66 & $0,82^{\mathrm{A}}$ \\
& \multicolumn{3}{|}{} \\
CLA & Valor de P & 0,0965 \\
Arm & 0,0395 & $<0,0001$ \\
CLA x Arm & 0,0016 & 0,5106 \\
CV (\%) & $<0,0001$ & 60,01 \\
\cline { 2 - 3 } & 0,54 & \\
\hline
\end{tabular}

Médias seguidas de letras distintas na mesma coluna diferem entre si pelo teste de Tukey $(\mathrm{p}<0,05)$.

Número de repetições $(n)=12$

Os ovos provenientes de matrizes que receberam a ração com inclusão de CLA apresentaram maiores pesos iniciais $\left(\mathrm{PO}_{\mathrm{i}}\right)$, quando comparados aos que não receberam (Tabela 3.1). Através da avaliação do desdobramento da interação sobre o peso do ovo inicial $\left(\mathrm{PO}_{\mathrm{i}}\right)$ na Tabela 3.2, nota-se que as matrizes que receberam CLA apresentaram ovos de pesos semelhantes no menor tempo de armazenamento (três dias), mais leves no sexto dia de armazenamento e mais pesados com nove dias de armazenamento. Os ovos do tratamento sem CLA não diferiram em $\mathrm{PO}_{\mathrm{i}}$ nos dois primeiros tempos de armazenamento (três e seis dias), porém, foram mais leves aos nove dias, efeito da perda de água, conforme comentado anteriormente. Estes resultados diferem dos encontrados por Suksombat et al. (2006), que 
verificaram redução do tamanho dos ovos com o aumento da inclusão de CLA nas dietas de matrizes $(0,1,2,3$ e 4\%) e dos apresentados por Franco (2007) suplementando 0,00; 0,18; 0,36 e 0,54 de CLA, respectivamente. Da mesma forma, Shang et. al. (2004) verificaram que o peso do ovo decresceu conforme aumentou o CLA dietético. Já Aydin \& Cook (2004) encontraram resultados similares utilizando 0,25\% CLA, e observaram o aumento do peso do ovo. Os efeitos adversos da inclusão do CLA sobre o peso do ovo neste estudo podem ter sido minimizados pelo nível de inclusão utilizado (0,023\% de CLA) em relação à literatura. Por outro lado, o armazenamento reduziu o POi assim como a perda de peso do ovo (PPO), conforme esperado devido à perda de água para o ambiente através dos poros da casca (Macari et al., 2013; Oliveira \& Oliveira, 2013).

Tabela 3.2 Desdobramento da interação entre tempos de armazenamento e inclusão ou não de CLA no peso do ovo inicial $\left(\mathrm{PO}_{\mathrm{i}}\right)$

\begin{tabular}{|c|c|c|c|c|c|}
\hline \multirow[t]{2}{*}{ Tratamentos } & \multicolumn{3}{|c|}{ Tempo de Armazenamento } & \multirow[t]{2}{*}{$\mathrm{P}$} & \multirow[t]{2}{*}{$\mathrm{CV} \%$} \\
\hline & 3 & 6 & 9 & & \\
\hline Com CLA & $68,88^{\mathrm{a}}$ & $68,32^{\mathrm{bB}}$ & $69,01^{\mathrm{aA}}$ & $<0,0001$ & 0,04 \\
\hline Sem CLA & $68,75^{\mathrm{a}}$ & $68,72^{\mathrm{aA}}$ & $68,32^{\mathrm{bB}}$ & $<0,0001$ & 0,04 \\
\hline
\end{tabular}

Médias seguidas de letras diferentes minúsculas na linha e maiúsculas na coluna diferem entre si pelo teste de Tukey $(\mathrm{P}<0,05)$

5.1.2 Rendimento de incubação e mortalidade embrionária

A adição do CLA na ração das matrizes pesadas e os diferentes tempos de armazenamento dos ovos sobre parâmetros de produtividade dos pintos e mortalidade embrionária (Tabela 3.3) apresentou somente efeito na mortalidade embrionária final (15 a 21) dias e nos pintos bicado vivo (BicV). Por outro lado, os períodos de armazenamento afetaram a taxa de eclosão (TXEC), eclodibilidade (ECL), mortalidade embrionária total (MET), mortalidade embrionária (0 a 7) e pintos bicado vivo (BicV).

Neste sentido, os índices de fertilidade (FERT) e taxa de eclosão (TXEC) encontradas neste estudo foram inferiores a estudos anteriores, que relataram cerca de 97,7\% FERT, 87,5\% TXEC utilizando matrizes com cerca de 32 semanas de idade (Fasenko et al., 2001) e cerca de $82,5 \%$ TXEC para matrizes de 41 a 50 semanas de idade (Reijrink et al., 2010). Os menores valores encontrados no presente estudo se justificam pelo fato das matrizes terem idade mais avançada, pois a qualidade do ovo declina à medida que a idade da matriz avança, de forma irreversível (Oliveira \& Oliveira, 2013). Poedeiras jovens apresentam 
melhor qualidade de albúmen quando comparadas com aves mais velhas (Santos et al., 2009). De acordo com Macari et al. (2013), as causas de infertilidade necessitam de maior investigação nas granjas de matrizes, podendo ser causada por interações farmacológicas, inclusive nas rações, manejo dos machos, proporção machos:fêmeas, peso das aves, malformações dos membros inferiores, nutrição, idade etc.

Com exceção no número de pintos bicados mortos, todos os índices referentes aos resultados de incubação obtidos neste estudo foram inferiores aos parâmetros estipulados por Macari et al. (2013), sendo: valores de infertilidade de 3,0 a 10,0\%; mortalidade fase I de 2,0 a 4,0\%; mortalidade fase II de 0,5 a $0,7 \%$; mortalidade fase III de 2,0 a 4,0\%; bicado morto de 0,7 a $0,9 \%$. Rosa \& Ávila (2000) citam valores ideais de 88 e $96 \%$ para eclosão e eclodibilidade, respectivamente.

Tabela 3.3 Valores médios percentuais (\%) de fertilidade (FERT), taxa de eclosão (TXEC), eclodibilidade (ECL), mortalidade embrionária total (MET), mortalidade embrionária (0 a 7), (8 a 14) e (15 a 21) dias, bicado vivo (BicV) e bicado morto (BicM) de ovos armazenados durante 3, 6 e 9 dias com e sem inclusão de CLA

\begin{tabular}{cccccccccc}
\hline Tratamentos & FERT & TXEC & ECL & MET & $0-7$ & $8-14$ & $15-21$ & BicV & BicM \\
\hline C/CLA & 80,20 & 59,07 & 70,86 & 16,84 & 8,22 & 1,85 & $5,38^{\mathrm{A}}$ & 0,40 & 0,29 \\
S/ CLA & 79,27 & 57,75 & 69,95 & 15,45 & 8,91 & 1,50 & $3,65^{\mathrm{B}}$ & 1,21 & 0,35 \\
Arm3 & 77,71 & 62,30 & 76,91 & 12,24 & 4,78 & 1,39 & 4,78 & 0,35 & 0,35 \\
Arm6 & 79,48 & 60,13 & 72,74 & 13,63 & 6,51 & 1,47 & 4,21 & 0,35 & 0,35 \\
Arm9 & 82,01 & 52,80 & 61,57 & 22,57 & 14,41 & 2,17 & 4,56 & 1,73 & 0,26 \\
\cline { 2 - 10 } & \multicolumn{7}{c}{ Valor de P } \\
CLA & 0,6418 & 0,6415 & 0,7541 & 0,3355 & 0,5222 & 0,4063 & 0,0007 & 0,0213 & 0,7766 \\
Arm & 0,2195 & 0,0254 & 0,0005 & $<0,0001$ & $<0,0001$ & 0,2526 & 0,6368 & 0,0020 & 0,9215 \\
CLA x Arm & 0,3832 & 0,0042 & 0,0047 & 0,0011 & 0,0039 & 0,6639 & 0,3175 & 0,0356 & 0,1465 \\
CV (\%) & 7,17 & 16,02 & 14,66 & 38,63 & 63,34 & 80,06 & 49,30 & 173,63 & 174,42 \\
\hline
\end{tabular}

Número de repetições $(\mathrm{n})=12$

Observando o desdobramento da interação entre inclusão de CLA e armazenamento dos ovos incubáveis (Tabela 3.4), nota-se que inclusão de CLA resultou em maior taxa de eclosão (TXEC) para os ovos armazenados por maior período (nove dias) quando comparados aos pintos que não receberam CLA, sendo 14,83\% melhor. Os ovos que receberam CLA não diferiram quanto à TXEC com o aumento dos tempos de armazenamento, já os ovos sem CLA apresentaram redução na TXEC com nove dias de armazenamento. Esses resultados foram diferentes dos apresentados por Franco (2007), que encontraram taxas de eclodibilidade menores com aumento da inclusão de CLA (de zero até 0,54\%). Essas diferenças podem ser justificadas pelo nível de inclusão utilizado na dieta das matrizes neste estudo, que foi inferior $(0,023 \%)$, com a finalidade de evitar os efeitos deletérios do CLA descritos anteriormente na literatura (Aydin e Cook, 2009). Segundo estes 
autores, dietas de poedeiras com inclusão de 0,5\% de CLA provocaram 100\% de mortalidade embrionária em ovos férteis e também em codornas japonesas (Aydin e Cook, 2004).

Tabela 3.4 Desdobramento da interação entre tempos de armazenamento e inclusão ou não de CLA na taxa de eclosão dos pintos (TXEC)

\begin{tabular}{|c|c|c|c|c|c|}
\hline \multirow[t]{2}{*}{ Tratamentos } & \multicolumn{3}{|c|}{ Tempo de Armazenamento } & \multirow[t]{2}{*}{$\mathrm{P}$} & \multirow[t]{2}{*}{$\mathrm{CV} \%$} \\
\hline & 3 & 6 & 9 & & \\
\hline Com CLA & 57,33 & 59,68 & $60,22^{\mathrm{A}}$ & $<0,0001$ & 1,99 \\
\hline Sem CLA & $67,27^{\mathrm{a}}$ & $60,58^{a}$ & $45,39^{\mathrm{bB}}$ & $<0,0001$ & 1,99 \\
\hline
\end{tabular}

Médias seguidas de letras diferentes minúsculas na linha e maiúsculas na coluna diferem entre si pelo teste de Tukey $(\mathrm{P}<0,05)$

O desdobramento da interação entre inclusão de CLA e tempos de armazenamento dos ovos incubáveis para a eclodibilidade (ECL) pode ser observado na Tabela 3.5. Nota-se que, da mesma forma que a TXEC, a ECL foi maior para o tratamento que recebeu CLA aos nove dias de armazenamento, com resultado 15,38\% superior. Os índices de ECL do tratamento com CLA não diferiram entre si com o aumento do armazenamento, no entanto, no tratamento sem CLA, o maior tempo de armazenamento causou prejuízos à sobrevivência da progênie, o que pode indicar que a inclusão de $0,023 \%$ CLA na dieta das matrizes pode favorecer as TXEC e ECL para ovos armazenados por longos períodos, neste caso, nove dias. Fasenko et al. (2001) estudaram os efeitos dos tempos de armazenamento sobre a eclodibilidade e encontraram valores de $89,7 \%$ e $72,2 \%$ para ovos armazenados durante 4 e 14 dias, respectivamente. Estes últimos foram similares ao deste experimento para os ovos armazenados durante seis dias o que, mais uma vez, sugere a influência da idade das matrizes sobre estes índices.

Tabela 3.5 Desdobramento da interação entre tempos de armazenamento e inclusão ou não de CLA na eclodibilidade dos pintos (ECL)

\begin{tabular}{|c|c|c|c|c|c|}
\hline \multirow[t]{2}{*}{ Tratamentos } & \multicolumn{3}{|c|}{ Tempo de Armazenamento } & \multirow[t]{2}{*}{$\mathrm{P}$} & \multirow[t]{2}{*}{ CV\% } \\
\hline & 3 & 6 & 9 & & \\
\hline Com CLA & 72,48 & 70,86 & $69,25^{\mathrm{A}}$ & $<0,0001$ & 2,05 \\
\hline Sem CLA & $81,33^{\mathrm{a}}$ & $74,62^{\mathrm{a}}$ & $53,87^{\mathrm{bB}}$ & $<0,0001$ & 2,05 \\
\hline
\end{tabular}

Médias seguidas de letras diferentes minúsculas na linha e maiúsculas na coluna diferem entre si pelo teste de Tukey $(\mathrm{P}<0,05)$

Na Tabela 3.6 observam-se os resultados do desdobramento da interação entre inclusão de CLA e tempos de armazenamento para a mortalidade embrionária total (MET). Verifica-se que a inclusão de CLA aumentou a MET em ovos armazenados três e seis dias, que foram 5,38\% e 5,73\% maiores, quando comparados ao tratamento sem CLA nos mesmos períodos. No entanto, aos nove dias de armazenamento foi verificado menor MET com a 
utilização do CLA o que sugere que o nível de inclusão do CLA utilizado neste estudo pode ser benéfico para armazenamentos por longos períodos.

Tabela 3.6 Desdobramento da interação entre tempos de armazenamento e inclusão ou não de CLA na mortalidade embrionária total dos pintos (MET)

\begin{tabular}{|c|c|c|c|c|c|}
\hline \multirow[t]{2}{*}{ Tratamentos } & \multicolumn{3}{|c|}{ Tempo de Armazenamento } & \multirow[t]{2}{*}{$\mathrm{P}$} & \multirow[t]{2}{*}{$\mathrm{CV} \%$} \\
\hline & 3 & 6 & 9 & & \\
\hline Com CLA & $14,93^{\mathrm{A}}$ & $16,49^{\mathrm{A}}$ & $19,10^{\mathrm{B}}$ & $<0,0001$ & 1,00 \\
\hline Sem CLA & $9,55^{\mathrm{bB}}$ & $10,76^{\mathrm{bB}}$ & $26,04^{\mathrm{aA}}$ & $<0,0001$ & 1,00 \\
\hline
\end{tabular}

Médias seguidas de letras diferentes minúsculas na linha e maiúsculas na coluna diferem entre si pelo teste de Tukey $(\mathrm{P}<0,05)$

O aumento do tempo de armazenamento não afetou a MET para o tratamento com CLA, uma vez que os valores não diferiram entre si. No entanto, provocou aumento de $16,49 \%$ na MET para o tratamento sem CLA para os ovos armazenados durante nove dias em comparação aos menores tempos (três e seis dias). Estes resultados são semelhantes aos encontrados por Fasenko et al. (2001) sendo de 10,7\% e 27,7\% para ovos armazenados durante 4 e 14 dias, respectivamente.

Avaliando o desdobramento da interação entre inclusão de CLA e tempos de armazenamento de ovos incubáveis para a mortalidade embrionária inicial (0-7) de zero a sete dias (Tabela 3.7), observa-se que o aumento do período de armazenamento provocou maior mortalidade embrionária inicial a partir do sexto dia em ambos os tratamentos. Este fato que pode ser explicado pelo aumento da mortalidade celular durante o armazenamento afetar diretamente a viabilidade do embrião que, em determinado estágio da diferenciação celular, necessita de um número mínimo de células embrionárias viáveis para a continuidade no desenvolvimento embrionário normal, caso contrário, o desenvolvimento embrionário será paralisado, resultando em morte embrionária nos primeiros dias de incubação (Reijrink et al., 2010). Além disso, a reativação do processo de desenvolvimento embrionário após a paralisação por longos períodos de armazenamento normalmente provoca o aumento da mortalidade embrionária inicial (Fasenko et al., 2001). Segundo Tierzucht (2011), o embrião nesta fase do desenvolvimento possui de 40.000 a 60.000 células embrionárias viáveis em plena divisão, sendo assim, mortes nesta fase estão relacionadas ao manejo do ovo incubável, tendo como principais causas o tempo de armazenamento dos ovos férteis (longos ou curtos demais), condições da sala de armazenamento, idade da matriz, permanência do ovo no ninho por tempo prolongado, mudanças bruscas de temperatura e umidade, desinfecção dos ovos, falta do pré-aquecimento, condições da incubadora, qualidade da casca dos ovos, manejo nutricional das matrizes, micotoxinas ou enfermidades (Macari et al., 2013). 
Tabela 3.7 Desdobramento da interação entre tempos de armazenamento e inclusão ou não de CLA na mortalidade embrionária dos pintos de 0 a 7 dias de incubação

\begin{tabular}{|c|c|c|c|c|c|}
\hline \multirow[t]{2}{*}{ Tratamentos } & \multicolumn{3}{|c|}{ Tempo de Armazenamento } & \multirow[t]{2}{*}{$\mathrm{P}$} & \multirow[t]{2}{*}{$\mathrm{CV} \%$} \\
\hline & 3 & 6 & 9 & & \\
\hline Com CLA & $5,91^{\mathrm{b}}$ & $7,47^{b}$ & $11,28^{\mathrm{aB}}$ & $<0,0001$ & 0,76 \\
\hline Sem CLA & $3,65^{\mathrm{b}}$ & $5,56^{\mathrm{b}}$ & $17,54^{\mathrm{aA}}$ & $<0,0001$ & 0,76 \\
\hline
\end{tabular}

Médias seguidas de letras diferentes minúsculas na linha e maiúsculas na coluna diferem entre si pelo teste de Tukey $(\mathrm{P}<0,05)$

No entanto, o tratamento CLA promoveu menor mortalidade inicial para ovos armazenados durante nove dias, em relação ao tratamento sem CLA. Para alguns autores (Surai et al., 1996), nessa fase do desenvolvimento inicial, os embriões estão mais sujeitos à peroxidação lipídica devido à composição lipídica corporal ser majoritariamente de ácidos graxos poli-insaturados, associado às altas taxas metabólicas e de utilização de $\mathrm{CO}_{2}$. Neste estudo, a utilização de CLA pode ter exercido efeito antioxidante controlando o processo oxidativo de forma eficiente, especialmente durante o período de maior armazenamento. Este efeito antioxidante já foi relatado anteriormente (Ko et al., 2004) em estudos com frangos suplementados com 1,5\% de CLA em que o CLA afetou a atividade da catalase. Kim et al. (2005) encontraram atividade antioxidante do CLA sobre as enzimas antioxidantes glutationa peroxidase e superóxido dismutase em ratos suplementados com 1,5\% de CLA. A capacidade de certos isômeros do CLA em diminuir a oxidação lipídica pode estar associada à sua capacidade de fortalecer o sistema de defesa antioxidante (Ko et al., 2004) aumentando a capacidade de eliminação de radicais livres (Leung \& Liu, 2000).

Observando-se o desdobramento para a quantidade de pintos bicados vivos (BicV) na Tabela 3.8, nota-se que no tratamento com CLA não houve diferença para os índices de BicV entre os diferentes tempos de armazenamento. Por outro lado, no tratamento sem CLA, os índices foram semelhantes até os seis dias de armazenamento, mas aumentaram no $9^{\circ}$ dia. Para os ovos de matrizes que receberam CLA houve redução significativa do BicV no maior tempo de armazenamento, quando comparado ao tratamento sem CLA. 
Tabela 3.8 Desdobramento da interação entre tempos de armazenamento e inclusão ou não de CLA na mortalidade embrionária dos pintos bicados vivos à eclosão (BicV)

\begin{tabular}{|c|c|c|c|c|c|}
\hline \multirow[t]{2}{*}{ Tratamentos } & \multicolumn{3}{|c|}{ Tempo de Armazenamento } & \multirow[t]{2}{*}{$\mathrm{P}$} & \multirow[t]{2}{*}{$\mathrm{CV} \%$} \\
\hline & 3 & 6 & 9 & & \\
\hline Com CLA & 0,17 & 0,35 & $0,69^{\mathrm{B}}$ & 0,0966 & 0,24 \\
\hline Sem CLA & $0,52^{\mathrm{b}}$ & $0,35^{\mathrm{b}}$ & $2,78^{\mathrm{aA}}$ & $<0,0001$ & 0,24 \\
\hline
\end{tabular}

Médias seguidas de letras diferentes minúsculas na linha e maiúsculas na coluna diferem entre si pelo teste de Tukey $(\mathrm{P}<0,05)$

A mortalidade embrionária média de 8 a 14 dias, assim como a quantidade de pintos bicados mortos (BicM), não foram influenciadas pela inclusão de CLA na dieta das matrizes ou pelo armazenamento (Tabela 3.3), resultado diferente do encontrado por Fasenko et al. (2001).

Já a mortalidade embrionária final (de 15 a 21 dias) foi aumentada com a inclusão de CLA (Tabela 3.3), sem efeito do armazenamento, ao contrário do encontrado por Fasenko et al. (2001). Franco (2007) atribui os efeitos da mortalidade embrionária provocada pelo CLA às enzimas que catalisam o metabolismo de diversos ácidos graxos. Como citado por Aydin \& Cook (2009), o isômero trans-10, cis-12 diminui a atividade da estearoil-CoA dessaturase e inibe o processo de dessaturação dos ácidos graxos saturados, aumentando sua quantidade. É muito provável que esta enzima também possa ser responsável por modificar o transporte de alguns nutrientes essenciais ao desenvolvimento embrionário no ovo (Leone et al., 2009). Segundo Watkins et al. (2003), o CLA aumenta os níveis de ácidos graxos saturados na membrana do saco vitelino, o que pode aumentar a permeabilidade da membrana.

\subsubsection{Causas de mortalidade embrionária}

A inclusão de CLA ou os tempos de armazenamento não afetaram os parâmetros avaliados para mortalidade embrionária, conforme verificado na Tabela 3.9. Não houve interação entre os tratamentos para as causas de mortalidade dos pintinhos. 
Tabela 3.9 Valores médios percentuais (\%) de embriões contaminados (CT), contaminação fúngica (CTF), ovos trincados (TR) com posicionamento incorreto da cabeça (P1), posicionados de forma invertida ao polo do ovo (P2) e má formação embrionária (A1) provenientes de ovos armazenados durante 3, 6 e 9 dias com e sem inclusão de CLA

\begin{tabular}{ccccccc}
\hline Tratamentos & CT & CTF & TR & P1 & P2 & A1 \\
\hline C/CLA & 0,46 & 0,46 & 1,10 & 0,46 & 0,29 & 0,23 \\
S/ CLA & 0,17 & 0,35 & 1,10 & 0,35 & 0,06 & 0,14 \\
Arm3 & 0,61 & 0,56 & 0,87 & 0,26 & 0,09 & 0,09 \\
Arm6 & 0,17 & 0,35 & 1,13 & 0,35 & 0,35 & 0,17 \\
Arm9 & 0,17 & 0,30 & 1,30 & 0,61 & 0,09 & 0,26 \\
\cline { 2 - 7 } & 0,0985 & 0,3988 & 0,9989 & 0,5861 & 0,1129 & 0,3874 \\
CLA & 0,0702 & 0,2544 & 0,6784 & 0,3852 & 0,2394 & 0,5677 \\
Arm & 0,4526 & 0,0713 & 0,8322 & 0,3852 & 0,0565 & 0,2755 \\
CLA x Arm & 146,71 & 848,53 & 96,62 & 137,70 & 261,35 & 298,35 \\
CV $(\%)$ & \multicolumn{7}{c}{ Valor de P }
\end{tabular}

Número de repetições $(\mathrm{n})=12$

Vale ressaltar que todos os embriões que foram diagnosticados com posicionamento incorreto da cabeça $(\mathrm{P} 1)$ e posicionados de forma invertida ao polo do ovo (P2) estavam na fase de 19 a 21 dias de desenvolvimento embrionário, além disso, não foram encontrados embriões desidratados.

Os resultados encontrados neste estudo podem ser considerados dentro do padrão para P1 e P2, de acordo com os parâmetros estipulados por Macari et al. (2013): contaminados: $0,5 \%$; mal formações: $0,3 \%$ e má posição: 1 a $1,5 \%$.

5.1.3 Parâmetros físicos de qualidade dos pintos de um dia

Conforme pode ser observado na Tabela 3.10, embora não tenha sido verificado o efeito da inclusão de CLA sobre a qualidade dos pintos de uma forma geral, a qualidade declinou com o aumento do tempo de armazenamento, assim como observado por Reijrink et al. (2010). 
Tabela 3.10 Valores médios percentuais (\%) de mortos pós-eclosão (MPE), pintos de $1^{\mathrm{a}}$ linha $\left(1^{\mathrm{a}} \mathrm{L}\right)$, pintos de $2^{\mathrm{a}}$ linha $\left(2^{\mathrm{a}} \mathrm{L}\right)$ e pintos eliminados (ELIM) provenientes de ovos armazenados durante 3,6 e 9 dias com e sem inclusão de CLA

\begin{tabular}{ccccc}
\hline Tratamentos & MPE & $1^{\circ} \mathrm{L}$ & $2^{\circ} \mathrm{L}$ & ELIM \\
\hline C/CLA & 0,72 & 39,47 & 11,55 & 2,58 \\
S/ CLA & 0,55 & 40,03 & 9,14 & 1,97 \\
Arm3 & $1,00^{\mathrm{A}}$ & 42,71 & 10,46 & 2,46 \\
Arm6 & $0,25^{\mathrm{B}}$ & 42,67 & 9,25 & 1,87 \\
Arm9 & $0,67^{\mathrm{AB}}$ & 33,87 & 11,33 & 2,50 \\
\cline { 2 - 5 } & \multicolumn{4}{c}{ Valor de P } \\
CLA & 0,4787 & 0,7650 & 0,0902 & 0,1398 \\
Arm & 0,0379 & 0,0002 & 0,4817 & 0,3831 \\
CLA x Arm & 0,3123 & $<0,0001$ & 0,4494 & 0,3092 \\
CV $(\%)$ & 160,45 & 24,51 & 58,06 & 77,01 \\
\hline
\end{tabular}

Médias seguidas de letras distintas na mesma coluna diferem entre si pelo teste de Tukey $(\mathrm{p}<0,05)$.

Número de repetições $(\mathrm{n})=12$

Não houve interação dos tratamentos na mortalidade pós-eclosão (MPE), porém os piores resultados foram encontrados para ovos com três dias de armazenamento (Tabela 3.10).

A quantidade dos pintos de segunda linha $\left(2^{\mathrm{a}} \mathrm{L}\right)$ e a quantidade pintos eliminados (ELIM) também não foram influenciados pelos tratamentos. Em estudo semelhante, Reijrink et al. (2010) encontraram relação entre tempos de armazenamento e a quantidade de pintos classificados como de segunda linha, que foi superior para ovos armazenados por 14 dias (1,3\%), quando comparado ao de 4 dias $(0,7 \%)$.

$\mathrm{Na}$ Tabela 3.11 é possível avaliar os desdobramentos da interação entre inclusão de CLA e tempos de armazenamento para a porcentagem de pintos de primeira linha $\left(1^{a} \mathrm{~L}\right)$. Verificou-se que a inclusão do CLA diminuiu a porcentagem de pintos $1^{\mathrm{a} L}$ proveniente de ovos armazenados por três dias, o que não foi observado para seis dias de armazenamento. Enquanto que, para ovos armazenados por nove dias, a porcentagem de pintos $1^{\mathrm{a}} \mathrm{L}$ do tratamento com CLA foi superior. No tratamento com CLA não houve diferença entre os tempos de armazenamento, já para o tratamento sem CLA, os tempos três e seis não diferiram entre si, mas aos nove dias a quantidade de $1^{\mathrm{a}} \mathrm{L}$ foi menor. 
Tabela 3.11 Desdobramento da interação entre tempos de armazenamento e inclusão ou não de CLA para os pintos de um dia classificados como de primeira linha $\left(1^{\mathrm{a}} \mathrm{L}\right) \%$

\begin{tabular}{|c|c|c|c|c|c|}
\hline \multirow[t]{2}{*}{ Tratamentos } & \multicolumn{3}{|c|}{ Tempo de Armazenamento } & \multirow[t]{2}{*}{$\mathrm{P}$} & \multirow[t]{2}{*}{$\mathrm{CV} \%$} \\
\hline & 3 & 6 & 9 & & \\
\hline Com CLA & $38,25^{\mathrm{B}}$ & 40,42 & $39,75^{\mathrm{A}}$ & 0,0966 & 1,31 \\
\hline Sem CLA & $47,17^{\mathrm{aA}}$ & $44,92^{\mathrm{a}}$ & $28,00^{\mathrm{bB}}$ & $<0,0001$ & 1,31 \\
\hline
\end{tabular}

Médias seguidas de letras diferentes minúsculas na linha e maiúsculas na coluna diferem entre si pelo teste de Tukey $(\mathrm{P}<0,05)$

5.1.3.1 Avaliação da qualidade dos umbigos dos pintos de um dia

Nas avaliações de umbigo dos pintos de um dia (Tabela 3.12) deste experimento, os umbigos não cicatrizados e não eliminados (UNE) fizeram parte da contagem dos pintos de segunda linha, também chamados de pintos de seleção. Porém, nem todos os pintos de segunda linha tinham problemas de umbigo como também nem todos os pintos que foram eliminados o tinham.

Tabela 3.12 Valores médios percentuais (\%) de umbigos não cicatrizados e eliminados (UE), umbigos não cicatrizados e não eliminados (UNE) e total de umbigos não cicatrizados (UT) de pintos de um dia provenientes de ovos armazenados durante 3 , 6 e 9 dias com e sem inclusão de CLA

\begin{tabular}{cccc}
\hline Tratamentos & UE & UNE & UT \\
\hline C/CLA & 1,81 & 3,33 & 5,14 \\
S/ CLA & 1,53 & 3,75 & 5,28 \\
Arm3 & 1,83 & 3,33 & 5,17 \\
Arm6 & 1,58 & 3,25 & 4,83 \\
Arm9 & 1,58 & 4,04 & 5,62 \\
& & Valor de P & \\
CLA & 0,3478 & 0,5418 & 0,8621 \\
Arm & 0,7259 & 0,5815 & 0,7186 \\
CLA x Arm & 0,1093 & 0,2541 & 0,1183 \\
CV $(\%)$ & 75,36 & 80,97 & 64,93 \\
\hline
\end{tabular}

Número de repetições $(\mathrm{n})=12$

A adição do CLA ou o tempo de armazenamento dos ovos na sala de ovos não influenciaram a qualidade dos umbigos dos pintos de um dia, conforme o esperado. Segundo Macari et al. (2013), as infecções do umbigo são relacionadas diretamente com problemas de temperatura e umidade na incubadora ou mesmo com a presença de bactérias patogênicas. Além disso, também não foram verificadas interações significativas entre inclusão de CLA e tempos de armazenamento para este parâmetro de qualidade de pintos. 


\subsection{Morfometria dos órgãos}

A avaliação do peso do pinto ao nascimento é parâmetro muito importante para a indústria avícola. Willemsen et al. (2008) avaliaram a influência da qualidade do pinto no peso ao abate dos frangos e verificaram que o PP aos 7 dias foi o melhor indicativo de previsibilidade de peso corporal ao abate dos frangos, seguido pelo parâmetro de peso corporal do pinto de um dia. Neste estudo, a inclusão de CLA produziu pintinhos menores (Tabela 3.13), resultado similar ao encontrado por Reijrink et al. (2010) e diferente de Tona et al. (2004), que verificaram os efeitos negativos de longos períodos de armazenamento de ovos sobre o peso corporal dos pintinhos. Já Franco (2007), não verificou diferenças de PP provenientes de matrizes que receberam diferentes níveis de CLA e sem CLA. Já os períodos de armazenamento não influenciaram o PP.

Tabela 3.13 Valores médios, em gramas (g), de peso absoluto do pinto (PP), peso absoluto do pró-ventrículo e moela (PPM), peso absoluto do fígado (PF), peso absoluto do pâncreas (PPan), peso absoluto dos intestinos (PI) e peso absoluto do saco vitelino (PSV) de pintos de um dia provenientes de ovos armazenados durante 3, 6 e 9 dias com e sem inclusão de CLA

\begin{tabular}{ccccccc}
\hline Tratamentos & PP & PPM & PF & PPan & PI & PSV \\
\hline C/CLA & $44,38^{\mathrm{B}}$ & 3,13 & 1,31 & $0,08^{\mathrm{A}}$ & 2,03 & $4,39^{\mathrm{B}}$ \\
S/ CLA & $45,39^{\mathrm{A}}$ & 2,95 & 1,29 & $0,08^{\mathrm{B}}$ & 1,97 & $4,95^{\mathrm{A}}$ \\
Arm3 & 45,03 & 3,06 & 1,30 & 0,08 & 2,04 & 4,60 \\
Arm6 & 44,81 & 3,08 & 1,32 & 0,08 & 2,03 & 4,49 \\
Arm9 & 44,82 & 2,98 & 1,28 & 0,08 & 1,93 & 4,93 \\
\cline { 2 - 7 } & \multicolumn{7}{c}{ Valor de P } \\
CLA & 0,0036 & $<0,0001$ & 0,1272 & 0,0372 & 0,0988 & 0,0021 \\
Arm & 0,8318 & 0,1389 & 0,0839 & 0,3441 & 0,0588 & 0,1171 \\
CLA x Arm & 0,7405 & 0,0054 & 0,0003 & 0,2662 & 0,0493 & 0,2665 \\
CV $(\%)$ & 5,66 & 24,90 & 9,64 & 24,46 & 14,89 & 28,72 \\
\hline
\end{tabular}

Médias seguidas de letras distintas na mesma coluna diferem entre si pelo teste de Tukey $(\mathrm{p}<0,05)$. Número de repetições $(n)=35$

Pintos provenientes de matrizes que receberam CLA apresentaram maiores pesos absolutos de pró-ventrículo e moela (PPM) e pâncreas (PPan) (Tabela 3.13), mas sem influência dos tempos de armazenamento. Já os pesos absolutos do fígado (PF) e intestinos (PI) não foram afetados pela inclusão do CLA ou pelos os tempos de armazenamento.

A adição do CLA reduziu o peso absoluto dos sacos vitelinos (PSV) dos pintos (Tabela 3.13), o que indica uma maior taxa de absorção da gema. No entanto, isso não influenciou o peso vivo dos pintinhos, que foram menores com a inclusão do CLA ( $\mathrm{P}=0,036)$. Os resultados de menores tamanhos de sacos vitelinos à eclosão para pintos provenientes de 
ovos que receberam CLA também foram encontrados por Latour et al. (2000), porém esses animais apresentaram pouca mudança no PSV até dois dias de idade quando comparados aos pintos que não receberam CLA, porque, provavelmente, tiveram o sistema de remoção dos lipídios do saco vitelino prejudicado com aumento da concentração de 18:0 na gema explicado pela modificação na $\Delta$ 9-dessaturase, por conta disso, os pintos que não receberam CLA se adaptaram rapidamente até os seis dias de idade, atingindo mesmos PSV. Neste estudo, os PSV não foram afetados pelos tempos de armazenamento na sala de ovos e tampouco foi verificada interação significativa entre dos fatores principais, semelhante aos resultados reportados por Rocha (2011), que verificou que períodos de armazenamento de 3 e 7 dias não influenciaram nos pesos dos sacos vitelinos dos pintos à eclosão. As interações entre inclusão do CLA e armazenamento foram significativas para PPM, PF e PI, e os respectivos desdobramentos estão apresentados nas tabelas a seguir. Bem como neste estudo, Reijrink et al. (2010) não encontraram interações para o peso dos órgãos na avaliação morfométrica de pintos vindos de ovos armazenados durante 4 e 14 dias.

Através do desdobramento da interação entre tempos de armazenamento e inclusão de CLA sobre o PPM (Tabela 3.14), nota-se que o PPM dos pintos suplementados com CLA provenientes de ovos armazenados por três e nove dias foram mais pesados quando comparados aos controles, já os pintos de ovos armazenados por seis dias não diferiram. No tratamento com CLA, não houve diferença para o peso do PPM dos pintos provenientes de ovos armazenados por diferentes períodos e no tratamento sem CLA, os pintos provenientes de ovos armazenados por seis dias, produziram PPM mais pesados.

Tabela 3.14 Desdobramento da interação entre tempos de armazenamento e inclusão ou não de CLA no peso absoluto do pró-ventrículo e moela (g) dos pintos de um dia (PPM)

\begin{tabular}{|c|c|c|c|c|c|}
\hline \multirow[t]{2}{*}{ Tratamentos } & \multicolumn{3}{|c|}{ Tempo de Armazenamento } & \multirow[t]{2}{*}{$\mathrm{P}$} & \multirow[t]{2}{*}{$\mathrm{CV} \%$} \\
\hline & 3 & 6 & 9 & & \\
\hline Com CLA & $3,16^{\mathrm{A}}$ & 3,08 & $3,16^{\mathrm{A}}$ & $<0,0001$ & 0,03 \\
\hline Sem CLA & $2,96^{\mathrm{aB}}$ & $3,08^{\mathrm{a}}$ & $2,80^{\mathrm{bB}}$ & $<0,0001$ & 0,03 \\
\hline
\end{tabular}

Médias seguidas de letras diferentes minúsculas na linha e maiúsculas na coluna diferem entre si pelo teste de Tukey $(\mathrm{P}<0,05)$

Na Tabela 3.15 observam-se os desdobramentos da interação entre inclusão de CLA e tempos de armazenamento para o peso absoluto do fígado (PF). A inclusão do CLA produziu fígados mais pesados para pintos provenientes de ovos armazenados por três dias, conforme encontrado por Suksombat et al. (2007). Já para os armazenados por seis dias o resultado foi oposto, os fígados do tratamento com CLA foram mais leves e para os 
provenientes de ovos armazenados por nove dias não houve diferença significativa. Para o tratamento com inclusão do CLA, pintos dos ovos armazenados por três dias apresentaram maior PF que não diferiu dos dias seis e nove. Já no tratamento sem CLA, os maiores PF foram encontrados para os pintos dos ovos armazenados por seis dias, os demais tempos de armazenamento não diferiram entre si.

Tabela 3.15 Desdobramento da interação entre tempos de armazenamento e inclusão ou não de CLA no peso absoluto do fígado (g) dos pintos de um dia (PF)

\begin{tabular}{|c|c|c|c|c|c|}
\hline \multirow[t]{2}{*}{ Tratamentos } & \multicolumn{3}{|c|}{ Tempo de Armazenamento } & \multirow[t]{2}{*}{$\mathrm{P}$} & \multirow[t]{2}{*}{$\mathrm{CV} \%$} \\
\hline & 3 & 6 & 9 & & \\
\hline Com CLA & $1,35^{\mathrm{aA}}$ & $1,29^{\mathrm{bB}}$ & $1,29^{b}$ & $<0,0001$ & 0,01 \\
\hline Sem CLA & $1,24^{\mathrm{bB}}$ & $1,35^{\mathrm{aA}}$ & $1,26^{\mathrm{b}}$ & $<0,0001$ & 0,01 \\
\hline
\end{tabular}

Médias seguidas de letras diferentes minúsculas na linha e maiúsculas na coluna diferem entre si pelo teste de Tukey $(\mathrm{P}<0,05)$

Desdobrando-se a interação entre inclusão de CLA e tempos de armazenamento para o peso absoluto dos intestinos - PI (Tabela 3.16), a inclusão de CLA produziu intestinos mais pesados em pintos provenientes de ovos armazenados por três dias. No tratamento sem CLA o maior peso de intestinos foi verificado para os pintos provenientes de ovos armazenados durante seis dias, os demais não diferiram entre si.

Tabela 3.16 Desdobramento da interação entre tempos de armazenamento e inclusão ou não de CLA no peso absoluto dos intestinos dos pintos de um dia (PI) em (g)

\begin{tabular}{|c|c|c|c|c|c|}
\hline \multirow[t]{2}{*}{ Tratamentos } & \multicolumn{3}{|c|}{ Tempo de Armazenamento } & \multirow[t]{2}{*}{$\mathrm{P}$} & \multirow[t]{2}{*}{$\mathrm{CV} \%$} \\
\hline & 3 & 6 & 9 & & \\
\hline Com CLA & $2,11^{\mathrm{A}}$ & 1,99 & 1,99 & $<0,0001$ & 0,03 \\
\hline Sem CLA & $1,96^{\mathrm{abB}}$ & $2,07^{\mathrm{a}}$ & $1,87^{\mathrm{b}}$ & $<0,0001$ & 0,03 \\
\hline
\end{tabular}

Médias seguidas de letras diferentes minúsculas na linha e maiúsculas na coluna diferem entre si pelo teste de Tukey $(\mathrm{P}<0,05)$

Para os pesos relativos dos pintos e dos órgãos (Tabela 3.17), a inclusão de CLA afetou todos os parâmetros, já o armazenamento somente influenciou o peso relativo do pinto (PRel). Os pesos relativos dos órgãos tiveram maior relação com o CLA, pois os pesos dos pintos que receberam CLA foram menores (Tabela 3.14), uma vez que o peso relativo é a razão entre peso do órgão e do pinto. 
Tabela 3.17 Valores médios percentuais (\%) de pesos relativos do pinto (PPrel), próventrículo e moela (PPMrel), fígado (PFrel), pâncreas (PPanRel), intestinos (PIrel) e saco vitelino (PSVrel) de pintos de um dia provenientes de ovos armazenados durante 3, 6 e 9 dias com e sem inclusão de CLA

\begin{tabular}{ccccccc}
\hline Tratamentos & ${ }^{\mathrm{I}}$ PPrel & ${ }^{2}$ PPMrel & ${ }^{2}$ PFrel & ${ }^{2}$ PPanRel & ${ }^{2}$ PIrel & ${ }^{2}$ PSVrel \\
\hline C/CLA & $65,10^{\mathrm{B}}$ & 7,08 & 2,97 & $0,19^{\mathrm{A}}$ & $4,59^{\mathrm{A}}$ & $9,86^{\mathrm{B}}$ \\
S/ CLA & $66,59^{\mathrm{A}}$ & 6,50 & 2,84 & $0,17^{\mathrm{B}}$ & $4,34^{\mathrm{B}}$ & $10,87^{\mathrm{A}}$ \\
Arm3 & $65,32^{\mathrm{B}}$ & 6,83 & 2,90 & 0,18 & 4,54 & 10,19 \\
Arm6 & $65,24^{\mathrm{B}}$ & 6,88 & 2,96 & 0,18 & 4,55 & 9,93 \\
Arm9 & $66,98^{\mathrm{A}}$ & 6,66 & 2,85 & 0,17 & 4,31 & 10,97 \\
\cline { 2 - 7 } & \multicolumn{7}{c}{ Valor de P } \\
CLA & 0,0035 & $<0,0001$ & 0,0010 & 0,0042 & 0,0052 & 0,0059 \\
Arm & 0,0076 & 0,1298 & 0,0901 & 0,3798 & 0,0519 & 0,0540 \\
CLA x Arm & 0,1362 & 0,0139 & 0,0009 & 0,3845 & 0,0837 & 0,2376 \\
CV $(\%)$ & 5,82 & 23,17 & 10,24 & 24,93 & 15,18 & 26,34 \\
\hline
\end{tabular}

Médias seguidas de letras distintas na mesma coluna diferem entre si pelo teste de Tukey ( $\mathrm{p}<0,05)$.

Número de repetições $(\mathrm{n})=35$

${ }^{1}$ Peso relativo do pinto $(\%)=($ peso do pinto/peso do ovo $) \times 100$

${ }^{2}$ Peso relativo dos órgãos $(\%)=$ (peso do órgão/peso do pinto) $\times 100$

A inclusão de CLA nas rações das matrizes reduziu o PPrel, enquanto o aumento do tempo de armazenamento aumentou o PPrel. Os valores médios encontrados para o PPrel neste experimento foram inferiores aos descritos por Sahan et al, (2014), que encontraram valores em torno de 73,0\% para matrizes de 52 semanas.

Por outro lado, a inclusão de CLA aumentou os valores dos pesos relativos do pâncreas (PPanRel) e intestinos (PIrel), sem efeito dos períodos de armazenamento.

Assim como comentado anteriormente para o PSV, os pintos provenientes de matrizes que receberam CLA apresentaram menores valores de pero relativo do saco vitelino (PSVrel), não foram afetados pelo armazenamento e não foi verificada interação entre os tratamentos. Segundo o manual da linhagem (Cobb, 2013), o PSVrel deve apresentar valores menores do que $10 \%$, o que sugere maior absorção do saco vitelino pelo pintinho.

Os pesos relativos do pró-ventrículo e moela (PPMrel) e fígado (PFrel) foram afetados pela adição de CLA e pela interação entre os fatores principais. Desdobrando a interação para o PPMrel (Tabela 3.18) verifica-se que a inclusão do CLA produziu maiores valores de PPMrel nos pintinho provenientes de ovos armazenados aos três e nove dias e não diferiram para o tempo de armazenamento de seis dias. 
Tabela 3.18 Desdobramento da interação entre tempos de armazenamento e inclusão ou não de CLA no peso relativo (\%) do pró-ventrículo e moela dos pintos de um dia (PPMrel)

\begin{tabular}{|c|c|c|c|c|c|}
\hline \multirow[t]{2}{*}{ Tratamentos } & \multicolumn{3}{|c|}{ Tempo de Armazenamento } & \multirow[t]{2}{*}{$\mathrm{P}$} & \multirow[t]{2}{*}{$\mathrm{CV} \%$} \\
\hline & 3 & 6 & 9 & & \\
\hline Com CLA & $7,15^{\mathrm{A}}$ & 6,99 & $7,10^{\mathrm{A}}$ & $<0,0001$ & 0,06 \\
\hline Sem CLA & $6,50^{\mathrm{abB}}$ & $6,77^{\mathrm{a}}$ & $6,22^{\mathrm{bB}}$ & $<0,0001$ & 0,06 \\
\hline
\end{tabular}

Médias seguidas de letras diferentes minúsculas na linha e maiúsculas na coluna diferem entre si pelo teste de Tukey $(\mathrm{P}<0,05)$

Desdobrando-se a interação entre inclusão de CLA e tempos de armazenamento para o PFrel (Tabela 3.19), nota-se que a inclusão de CLA apresentou maior PFrel para pintos provenientes de 3 dias de armazenamento, sem diferença para os demais tempos de armazenamento. Quanto ao tratamento com CLA, o maior tempo de armazenamento produziu menores PFrel, sem diferença para os demais períodos. No tratamento sem CLA, o PFrel foi maior nos animais provenientes de ovos armazenados por seis dias, não diferindo entre os tempos três e nove de armazenamento.

Tabela 3.19 Desdobramento da interação entre tempos de armazenamento e inclusão ou não de CLA no peso relativo (\%) do fígado dos pintos de um dia (PFrel)

\begin{tabular}{|c|c|c|c|c|c|}
\hline \multirow[t]{2}{*}{ Tratamentos } & \multicolumn{3}{|c|}{ Tempo de Armazenamento } & \multirow[t]{2}{*}{$\mathrm{P}$} & \multirow[t]{2}{*}{$\mathrm{CV} \%$} \\
\hline & 3 & 6 & 9 & & \\
\hline Com CLA & $3,05^{\mathrm{aA}}$ & $2,94^{\mathrm{ab}}$ & $2,91^{b}$ & $<0,0001$ & 0,03 \\
\hline Sem CLA & $2,74^{\mathrm{bB}}$ & $2,98^{\mathrm{a}}$ & $2,80^{\mathrm{b}}$ & $<0,0001$ & 0,03 \\
\hline
\end{tabular}

Médias seguidas de letras diferentes minúsculas na linha e maiúsculas na coluna diferem entre si pelo teste de Tukey $(\mathrm{P}<0,05)$ 
Na Tabela 3.20, verifica-se que a inclusão de CLA influenciou no comprimento de intestinos total (CIT) e também o comprimento do intestino delgado (CID). Estas podem ser características interessantes para a produção de frangos, pois intestinos maiores podem resultar em maior a área de absorção alimentar. Além disso, o armazenamento durante nove dias reduziu o CIT e CID, sem diferença entre os tempos de armazenamento três e seis dias. Neste experimento, não foi encontrada interação entre os fatores principais para CIT ou CID. Além disso, o comprimento do reto (CR) não foi influenciado por nenhum dos tratamentos aplicados, nem foi verificada interação significativa.

Tabela 3.20 Valores médios de comprimento, em centímetros (cm), do intestino total (CIT), do intestino delgado (CID) e do reto (CR) de pintos de um dia provenientes de ovos armazenados durante 3, 6 e 9 dias com e sem inclusão de CLA

\begin{tabular}{cccc}
\hline Tratamentos & CIT & CID & CR \\
\hline C/CLA & $45,34^{\mathrm{A}}$ & $42,49^{\mathrm{A}}$ & 2,85 \\
S/ CLA & $43,09^{\mathrm{B}}$ & $40,25^{\mathrm{B}}$ & 2,84 \\
Arm3 & $44,64^{\mathrm{A}}$ & $41,78^{\mathrm{A}}$ & 2,86 \\
Arm6 & $45,17^{\mathrm{A}}$ & $42,22^{\mathrm{A}}$ & 2,94 \\
Arm9 & $42,86^{\mathrm{B}}$ & $40,12^{\mathrm{B}}$ & 2,74 \\
& \multicolumn{3}{|}{} \\
CLLA & $<0,0001$ & Valor de P & 0,8663 \\
Arm & 0,0002 & $<0,0001$ & 0,1189 \\
CLA x Arm & 0,2782 & 0,0005 & 0,1875 \\
CV $(\%)$ & 8,35 & 0,2552 & 20,91 \\
\hline
\end{tabular}

Médias seguidas de letras distintas na mesma coluna diferem entre si pelo teste de Tukey $(\mathrm{p}<0,05)$.

Número de repetições $(n)=35$ 
5.3 Oxidação lipídica dos sacos vitelinos de pintos de um dia

Observando os resultados são apresentados na Tabela 3.21, a inclusão de CLA na dieta das matrizes nos sacos vitelinos dos pintinhos, resultou em maiores valores de TBARSS, o que pode ser explicado pelos resultados encontrados para a absorção de gema. Por apresentarem maiores teores de absorção de gema, os pintos do tratamento com CLA realmente deveriam apresentar o processo oxidativo do saco vitelino mais acelerado, como foi verificado neste estudo. Isso porque o CLA induz a peroxidação lipídica dos fosfolipídios de cadeia longa (38:6, 36:4, 40:6) nos sacos vitelinos, principalmente em pintos provenientes de ovos armazenados (Cherian, 2009).

Tabela 3.21 Valores médios da avaliação das substâncias reativas ao ácido tiobarbitúrico dos sacos vitelinos (TBARSS) de pintos provenientes de ovos armazenados durante 3, 6 e 9 dias com e sem inclusão de CLA

\begin{tabular}{cc}
\hline Tratamentos & TBARSS \\
\hline C/CLA & $2,48^{\mathrm{A}}$ \\
S/ CLA & $2,23^{\mathrm{B}}$ \\
Arm3 & 2,30 \\
Arm6 & 2,45 \\
Arm9 & 2,32 \\
& Valor de P \\
CLA & 0,0302 \\
Arm & 0,4512 \\
CLA x Arm & 0,2415 \\
CV (\%) & 11,71 \\
\hline
\end{tabular}

Médias seguidas de letras distintas na mesma coluna diferem entre si pelo teste de Tukey $(\mathrm{p}<0,05)$. Número de repetições $(\mathrm{n})=2$ 


\section{CONCLUSÃO}

A inclusão dos isômeros cis-9, trans-11 e trans-10, cis-12 de CLA ao nível de $0,023 \%$ na dieta das matrizes pesadas produziu ovos mais pesados, mas reduziu o peso dos pintos, no entanto, estes apresentaram maior absorção do saco vitelino e maior comprimento do intestino. Além disso, melhorou alguns índices do rendimento de incubação, como a taxa de eclosão e a eclodibilidade, reduziu a mortalidade embrionária inicial, especialmente em ovos armazenados por nove dias, mas prejudicou o desenvolvimento final dos embriões. 


\section{REFERÊNCIAS BIBLIOGRÁFICAS}

AYDIN R.; COOK M. E. The effect of dietary conjugated linoleic acid on egg yolk fatty acids and hatchability in Japanese quail. Poultry Science, v. 83, p. 2016-2022, 2004.

AYDIN R.; COOK M.E. Maternal dietary conjugated linoleic acid is not directly toxic for the developing chick embryo, but causes embryo mortality by altering fatty acid composition of the egg yolk in the chicken. Journal of the Science of Food and Agriculture, v. 89, p. 2687-2691, 2009.

BARBOSA V.M., BAIÃO N.C., CARDEAL P.C., CARDOSO D.M., CUNHA C.E., LARA L.J.C., MARTINS N.R.S., MENDES P.M.M., MIRANDA D.J.A., NELSON D.L., POMPEU M.A., ROCHA J.S.R. Evaluation of egg shell quality from broiler breeder hens with different ages. Arquivo Brasileiro de Medicina Veterinária e Zootecnia, v.64, n.4, p.1036-1044, 2012.

BASU, S., A.; SMEDMAN; VESSBY B. Conjugated linoleic acid induces lipid peroxidation in humans. FEBS Letters. v. 468, p. 33-36, 2000.

CHERIAN G. Egg yolk conjugated linoleic acid alters phospholipid molecular species in chick tissues. European Journal of Lipid Science and Technology, v. 111, p. 546-552, 2009.

COBB. Guia de Manejo de Incubação (2013) L-1032-03

DEEMING D.C. Avian Incubation: behaviour, enviroment, and evolution. Lincoln: Oxford University Press; 2002

DU, M., DU. A., KC N., Sell. J. L. Volatile profiles and lipid oxidation of irradiated cooked chicken meat from laying hens fed diets containing conjugated linoleic acid. Poultry Science, v. 80, p. 235-241, 2001. 
EFSA. Journal. 2016. Safety and efficacy of methylester of conjugated linoleic acid (t10,c12 isomer) for pigs for fattening, sows and cows. EFSA Journal [1831-4732] vol:14, n. $1,2016$.

FASENKO, G. M., KREMENIUK K. M., ROBINSON F. E., WHELAN A. I., WALKER A. Prestorage incubation of long-term stored broiler breeder eggs. 1. Effects on hatchability. Poultry Science, v. 80, p. 1406-1411, 2001.

FASENKO, G. M. Egg Storage and the Embryo. Poultry Science, v. 86, n. 5, p. 1020-1024 doi:10.1093/ps/86.5.1020, 2007.

FRANCO, E. Z, Efeito do ácido linoléico conjugado na dieta de matrizes de corte e sua [tese] (mestrado) Santa Maria (RS): Universidade Federal de Santa Maria, 2007

JOO, S. T., LEE J. I., HÁ Y. L., PARK. G. B. Effects of dietary conjugated linoleic acid on fatty acid composition, lipid oxidation, color, and water-holding capacity of pork loin.J. Animal Science, v. 80, p.108-112, 2002.

KILIAN, M., I. MAUTSCH, J. I. GREGOR, P. STAHLKNECHT, C. A. JACOBI, I. SCHIMKE, H. GUSKI AND F. A. WENGER. Influence of conjugated linoleic acid vs. conventional linoleic acid on liver metastasis and hepatic lipid peroxidation in BOP-induced pancreatic cancer in Syrian hamster. Essential Fatty Acids, v. 67, p. 223-228, 2002.

KIM JH, HUBBARD NE, ZIBOH V, ERICKSON KL. Attenuation of breast tumor cell growth by conjugated linoleic acid via inhibition of 5-lipoxygenase activating protein. Biochimica et Biophysica Acta, v. 1736, n. 3, p. 244-50, 2005.

KO Y.H., JANG I. S, YANG H.Y. Effect of Conjugated Linoleic Acid on Intestinal and Hepatic Antioxidant Enzyme Activity and Lipid Peroxidation in Broiler Chickens. Aust. J. Animal Science, v. 17, n. 8, p. 1162-1167, 2004.

KUCERA P.; RADDATZ E.; BAROFFIO A. Respiration and metabolism of embrionic vertebrates. Oxigen and glucose uptake in the early chick embrio. Holanda, p299-309; 1984.

LATOUR M.A., DEVITT A.A., MEUNIER R.A., STEWART J.J., WATKINS B.A. Effects of Conjugated Linoleic Acid. 1. Fatty Acid Modification of Yolks and Neonatal Fatty Acid Metabolism. Poultry Science, v. 79, p. 817-821, 2000.

LEONE V.A., AYDIN R., COOK M.E, STRANSKY D.L. Evidence for conjugated linoleic acid-induced embryonic mortality that is independent of egg storage conditions and changes in egg relative fatty acids. Poultry Science, v. 88, p. 1858-1868, 2009.

LEUNG, Y.H.; LIU R.H. Trans-10, cis-12-conjugated linoleic acid isomer exhibits stronger oxy radical scavenging capacity than cis-9, trans11-conjugated linoleic acid isomer Journal of Agricultural and Food Chemistry, v. 48, p. 5469-5475, 2000.

MACARI, M.; GONZALES, E.; MARTINS, P.C.; NÄÄS, I.A.; PATRÍCIO, I.S. Manejo da Incubação. 3 ed. Jaboticabal: FACTA, 2013. 468p 
MEIJERHOF R.; BEEK G. Van. Mathematical modelling of temperature and moisture loss of hatching eggs. Journal Theoretical Biology. v. 163, p. 27-41, 1993.

MORAN E. T. Nutririon of the developing embryo and hatchling. Poultry Science; v. 80, p. 1043-1049, 2007.

NOBLE, R. C.; SHAND. J. H. Unsaturated fatty acid compositional changes and desaturation during the embryonic development of the chicken. Lipids v. 20, p. 278-282, 1985.

OLIVEIRA, B.L.de; OLIVEIRA, D.D.de. Qualidade e tecnologia de ovos. Lavras: Ed. UFLA, 2013. 224p.

PARK Y.; PARIZA M.W. Mechanisms of body fat modulation by conjugated linoleic acid (CLA). Food Research International, v. 40, p. 311-323, 2007.

REIJRINK I. A. M., BERGHMANS D., BRAND H. van den, KEMP B., MEIJERHOF R. Influence of egg storage time and preincubation warming profile on embryonic development, hatchability, and chick quality. Poultry Science, v. 89, p. 1225-1238, 2010.

ROCHA, J. S. R.R. Efeito da cantaxantina dietética para matrizes pesadas com idade avançada e do período de armazenamento dos ovos sobre a fertilidade, rendimento de incubação, nutrientes da gema e desenvolvimento embrionário [tese] (Doutorado), Universidade Federal de Minas Gerais, Escola de Veterinária 80 p.: il., 2011.

ROSA P. S.; AVILA, V. S. Variáveis relacionadas ao rendimento da incubação de ovos em matrizes de frangos de corte. CT / 246 / Embrapa Suínos e Aves, p. 1-3, 2000.

ŞAHAN, U ; IPEK, A ; SOZCU, A. Yolk sac fatty acid composition, yolk absorption, embryo development, and chick quality during incubation in eggs from young and old broiler breeders. Poultry Science Vol. 93(8), pp.2069-2077, 2014.

SANTOS, M. S. V; ESPÍNDOLA, G.B; LÔBO, R. N. B.; FREITAS, E. R.; José Lúcio Lima GUERRA, J. L. L.; SANTOS, A. B. E. Effect of temperature and storage of eggs. Ciência e Tecnologia de Alimentos, v. 29, n. 3, p. 513-517, 2009.

SHANG, X. G., WANG F. L.; LI D. F., YIN J. D.,; LI J. Y. Effects of conjugated linoleic acid on the productivity of laying hens and egg quality during refrigerated storage. Poultry Science, v. 83, p. 1688-1695, 2004.

STANGLE, G. High dietary levels of a conjugated linoleic acid mixture alter hepatic glycerophospholipid-carrying serum lipoproteins of rats. The Journal of Nutritional Biochemistry, v. 11, p. 184-191, 2000.

SUKSOMBAT. W.; LOUNGLAWAN P.; SAMITAYOTIN S. Effects of Conjugated Linoleic Acid Supplementation in Layer Diet on Fatty Acid Compositions of Egg Yolk and Layer Performances. Poultry Science, v. 85, p. 1603-1609, 2006.

SURAI P. F., NOBLE R. C., BRIAN K. SPEAKE A. Tissue-specific differences in antioxidant distribution and susceptibility to lipid peroxidation during development of the chick embryo. Biochimica et Biophysica Acta, v. 1304, p. 1-10, 1996. 
TIERZUCHT, L. Manegement Guide: Hatchery, 2011.

TONA, K.; BAMELIS F.; KETELAERE, B. de; BRUGGEMAN, V.; MOREAS, V. M. B.; BUYSE, J.; ONAGBESAN, O.; DECUYPERE, E. Effects of egg storage time on spread of hatch, chick quality, and chick juvenile growth. Poultry Science, v. 82, p. 736-741, 2003.

TONA, K. O. Onagbesan, B. De Ketelaere, E. Decuypere, and V. Bruggeman. Effects of age of broiler breeders and egg storage on egg quality, hatchability, chick quality, chick weight, and post-hatch growth to forty-two days. The Journal of Applied Poultry Research, v. 13, p. 10-18, 2004.

WATKINS, B. A.; FENG, S.; STROM, A. K.; DEVITT, A. A.; YU, L.; LI, Y. Conjugated linoleic acids alter the fatty acid composition and physical properties of egg yolk and albumen. Journal of Agricultural and Food Chemistry, v. 51, p. 6870-6876, 2003.

WILLEMSEN, H.; EVERAERT, N.; WITTERS, A.; DE SMIT, L.; DEBONNE, M.; VERSCHUERE, F.; GARAIN, P.; BERCKMANS, D.; DECUYPERE, E.; BRUGGEMAN. V. Critical assessment of chick quality measurements as an indicator of posthatch performance. Poultry Science, v. 87, p. 2358-2366, 2008. 